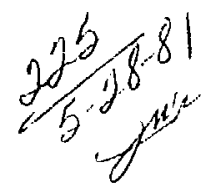
(1)

\section{MASTER R- 4632}

Lh. 2676

UCRL-53065 Vol. I

\title{
Status report on the geology of the Lawrence Livermore \\ National Laboratory site and adjacent areas
}

Volume I: Text and Appendices A-E

D. W. Carpenter, K. P. Puchlik, A. L. Ramirez

J. L. Wagoner, K. G. Knauss and P. W. Kasameyer

October 1980

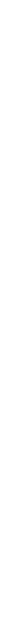


UCRL-53065 Vol. 1

Distribution Category UC-11

\title{
Status report on the geology of the Lawrence Livermore National Laboratory site and adjacent areas
} Volume I: Text and Appendices A-E

\author{
D. W. Carpenter, K. P. Puchlik, A. L. Ramirez
}

J. L. Wagoner, K. G. Knauss and P. W. Kasameyer

Manuscript date: October 1980

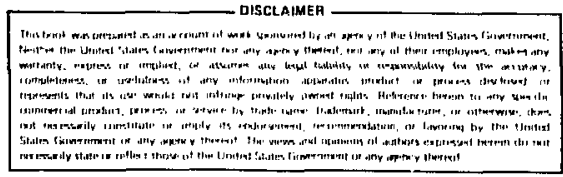

LAWRENCE LIVERMORE LABORATORY University of California - Livermore, California 94550 


\title{
ACKNOWLEDGMENTS
}

The authors of this report wish to recognize, with appreciation, that many persons contributed to its preparation.

Among these persons are Earth Sciences Division Leader Robert N. Schock, Project Manager James F. Scheimer, and Engineering Geology Group Leader Harold C. Ganow. These individuals provided technical and administrative expertise necessary to keep project investigations on track. Dennis W. Peifer, Technician Associatc provided critical logistical support and supervision of laborers and aided greatly in trench logging and preparation of drawings. Sandra Vinson and Robert R. Poulin prepared and expedited contract documents, and construction inspector Bill Martz provided invaluable liaison with contractor forces and the LLNL Facilities Engineering Department.

California State University, Hayward students Robert Clark, Jim Springer, and Frank Ciminesi provided capable assistance during trench preparation and logging.

The cooperation and assistance of the Sandia National Laboratory, Livermore, extended through Plant Enpincer William E. Thompson, is gratefully acknowledged.

The authors of this report also benefited greatly from informal discussions with geoscience personnel from federal, state, and local agencies who examined the exploratory trenches and other excavations that provided essential field data for this study. These professional colleagues include:

\author{
U. S. Geological Survey \\ Earl Brabb \\ Darrell Herd \\ California Department of Water Resources \\ Robert J. Akers \\ Louis T. Dudley \\ Jack W. Marlette \\ California Division of Mines and Geology \\ Glenn Borcherdt \\ Earl W. Hart \\ Ed Levias \\ Trinda Bedrossian Ristau \\ Alameda County Public Works Agency \\ Charles R. Comstock
}

Independent professional review and critique of this report has been provided by Woodward-Clyde Consultants (San Francisco Oflice) staff members Charles L. Taylor and Roy F. McKinney. Exploratory trenches and several other exposures studied as part of this investigation were viewed at various times by the following Woodward-Clyde Consultants staff members:

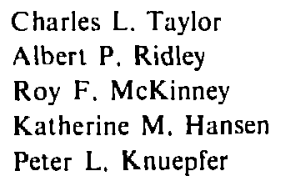

Woodward-Clyde Consultants has been retained by LLNL to provide professional review services in accordance with generally accepted professional practices and with the recommendations of the State of California Seismic Safety Commission for peer review of seismic hazards reports.

It must be emphasized that the above individuals and agencies should not be considered to have approved or otherwise endorsed the findings and conclusions contained in this report. The findings and conclusions reported herein are solely those of the authors, who are members of the Lawrence Livermore National Laboratory staff, 


\section{CONTENTS \\ VOLUME I}

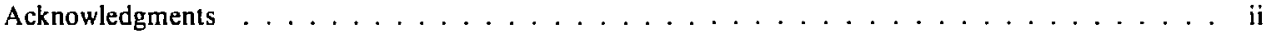

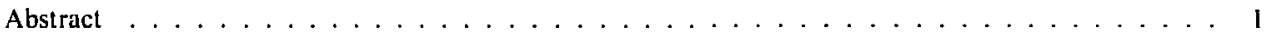

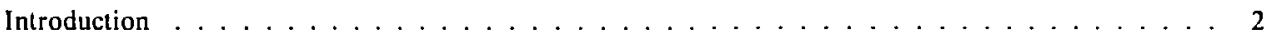

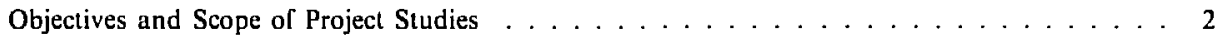

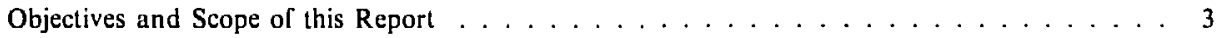

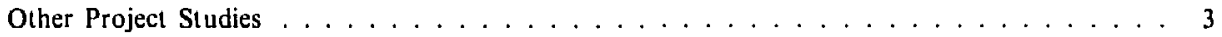

Lawrence Livermore National Laboratory Site . . . . . . . . . . . . . . . . . . . . . 4

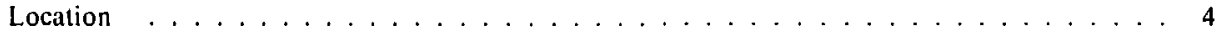

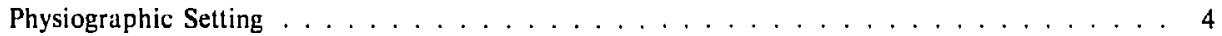

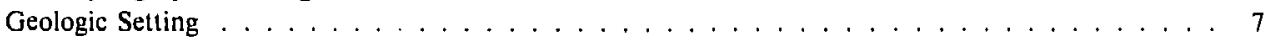

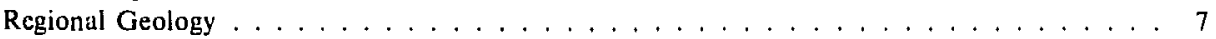

Geology of the Livermore Valley and Adjacent Areas . . . . . . . . . . . . . . 11

Previous Studies $\ldots \ldots \ldots \ldots \ldots \ldots \ldots$

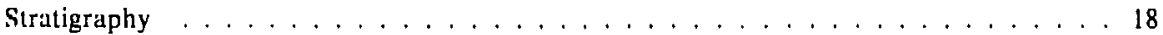

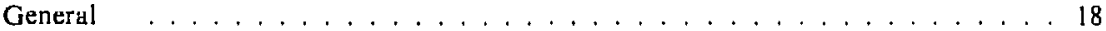

Jurassic-Cretaceous Igneous and Metamorphic Rocks . . . . . . . . . . . . . . 18

Late Mesozoic-Late Tertiary Marine Sedimentary Rocks . . . . . . . . . . . . . 18

Late Tertiary to Holocene Sediments . . . . . . . . . . . . . . . . 21

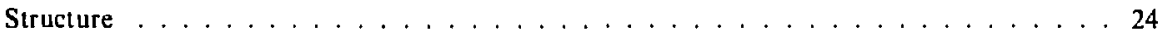

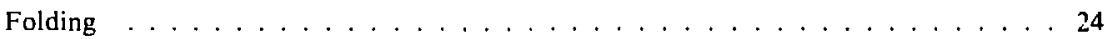

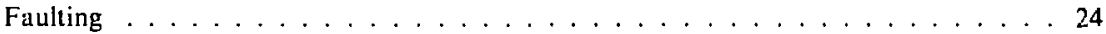

Major Active Bay Area Faults . . . . . . . . . . . . . . . . 24

San Andreas Fault . . . . . . . . . . . . . . . . . . . 24

Hayward Fault . . . . . . . . . . . . . . . . 26

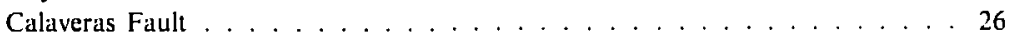

Faults in Livermore Valley and Adjacent Areas . . . . . . . . . . . 26

Carnegie Fault . . . . . . . . . . . . . . . . . . . . 29

Corral Hollow Fault . . . . . . . . . . . . . . . . 30

Doutherty Fault . . . . . . . . . . . . . . . . 30

Greenville Fault . . . . . . . . . . . . . . . . . 33

Las Positas Fault . . . . . . . . . . . . . . . . . . . 41

Livermore Fault . . . . . . . . . . . . . . . . . 52

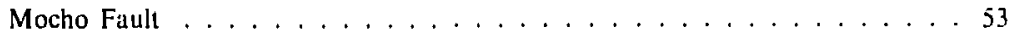

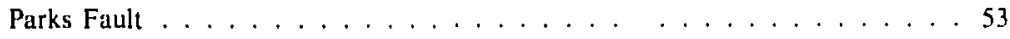

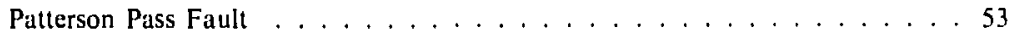

Pleasanton Fault . . . . . . . . . . . . . . . 53

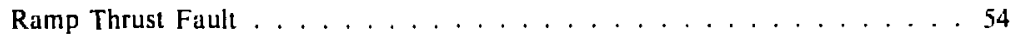

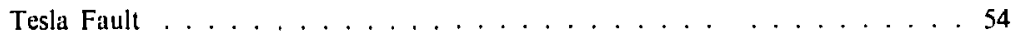

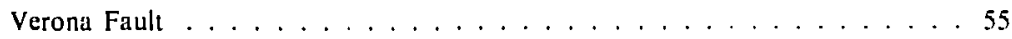

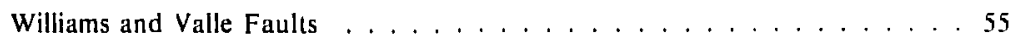

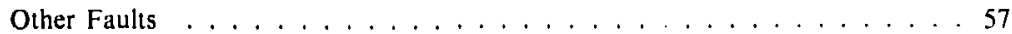

Geodetic Measurements . . . . . . . . . . . . . . . 57

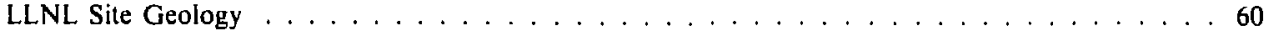

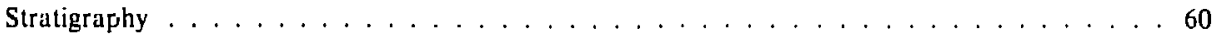

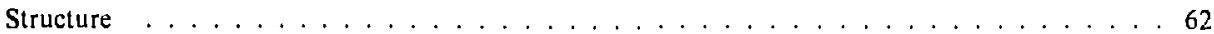

Summary and Conclusions $\ldots \ldots \ldots \ldots \ldots$

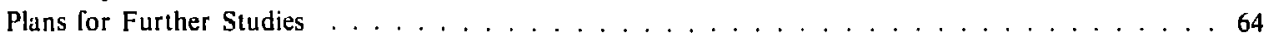

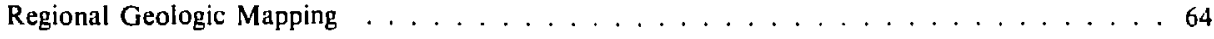




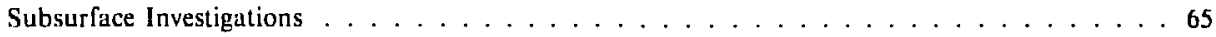

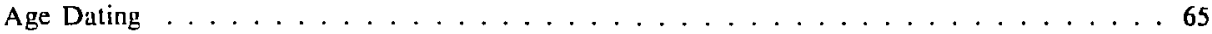

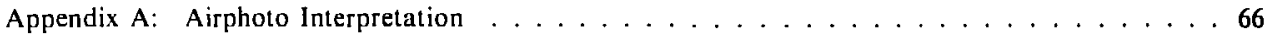

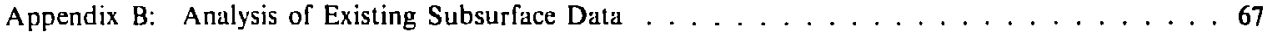

Appendix C: Uranium-Series Dating of Pedogenic Carbonates

From the Livermore Valley . . . . . . . . . . . . . . . . . . 73

Appendix D: Geophysical Exploration . . . . . . . . . . . . . . . . 80

Appendix E: Field Observations of Surface Faulting, Livermore Valley

Earthquake Series $\ldots \ldots \ldots \ldots$

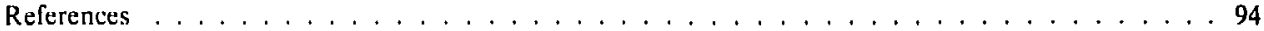

\section{VOLUME II \\ Appendix F: Site Exploration}

Preface and Introduction $\ldots \ldots \ldots \ldots \ldots \ldots \ldots \ldots$

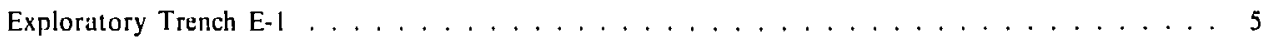

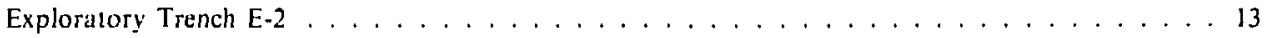

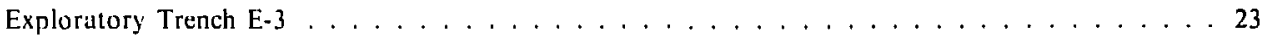

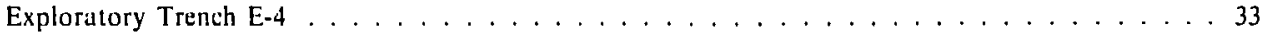

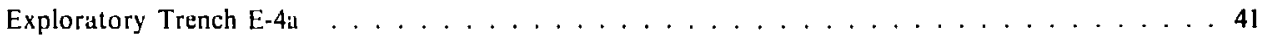

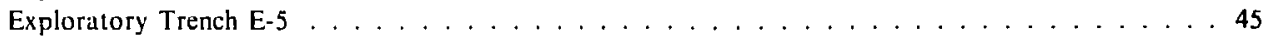

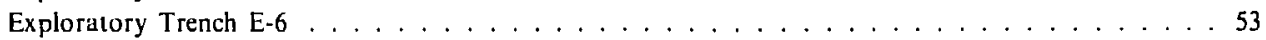

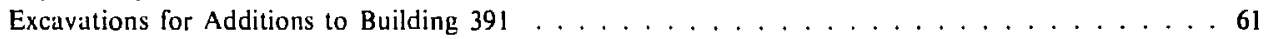

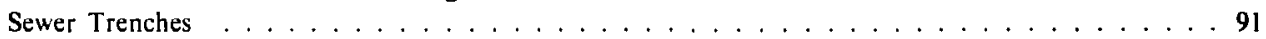

Other Mapped Exposures . . . . . . . . . . . . . . . . . . . . 107 


\title{
Status report on the geology of the Lawrence Livermore \\ National Laboratory site and adjacent areas
}

\begin{abstract}
In April, 1979, geoscience personnel at Lawrence Livermore National Laboratory (LLNL) initiated comprehensive geologic, seismologic, and hydrologic investigations of the LLNL site and nearby areas. These investigations have two objectives:

1. To obtain data for use in preparing a Final Environmental Impact Report for LLNL, pursuant to the National Environmental Policy Act.

2. To obtain data for use in improving the determination of a design basis earthquake for structural analysis of LLNL facilities.

The first phases of these investigations have been completed. Work completed to date includes a comprehensive literature review, analyses of three sets of aerial photographs, reconnaissance geophysical surveys, examination of existing LLNL site borehole data, and the logging of seven exploratory trenches, segments of two sewer trenches, a deep building foundation excavation, a road cut, and an enlarged creek bank exposure. One absolute age date has been obtained by the ${ }^{14} \mathrm{C}$ method and several dates of pedogenic carbonate formation have been obtained by the $230 \mathrm{Th} / 234 \mathrm{U}$ method. A seismic monitoring network has been established, and planning for a site hydrologic monitoring program and strong motion instrument network has been completed. The seismologic and hydrologic investigations are beyond the scope of this report and will be discussed separately in future documents.

LLNL is located in the southeast portion of the Livermore Valley, a structural and topographic depression that trends normal to the structural grain of the Central California Diablo Range, within which it is located. The Diablo Range consists dominantly of metamorphic and igneous rocks of the Jurassic-Cretaceous Franciscan Assemblage. The Diablo Range is generally bounded to the west by the active San Andreas Fault system and to the east by the Coast Range Thrust Fault system. The San Andreas Fault system is a right lateral strike-slip fault system along which the Pacific Plate and the North American Plate are currently moving past one another. The Coast Range Thrust Fault system marks the location of an extinct subduction zone along which rocks of the Franciscan Assemblage and marine sedimentary rocks of late Mesozoic through late Tertiary age are juxtaposed.

Livermore Valley itseif is underlain by up to 4,000 feet of predominately continental alluvial deposits of late Tertiary and Quaternary age. The active Calaveras and Greenville Fault zones bound the Valley on the west and east, respectively, while the active Las Positas Fault traverses at least a portion of the southern margin of the Valley. As discussed in this report, previous investigators have postulated thirteen other major and many minor faults within and near the Livermore Valley. Three of these, the Corral Hollow, Doutherty and Tesla Faults have been projected across LLNL by some previous investigators.
\end{abstract}


Within LLNL no evidence for the Corral Hollow or Doutherty Faults has been found in exploratory trenches and excavations made across their postulated locations. Undisturbed strata exposed in these trenches and excavations are of late Quaternary age, based upon soil profile development and dating of pedogenic carbonates by the $230 \mathrm{Th} / 234 \mathrm{U}$ method.

Exploration within Sandia National Laboratory, Livermore (SNLL) property, which adjoins LLNL on the south, has confirmed late Quaternary and possibly Holocene activity along the Las Positas Fault zone. A ${ }^{14} \mathrm{C}$ age of $17400 \pm 250 \mathrm{yr}$ has been obtained for a wood sample preserved in the lower portion of an alluvial sequence displaced by the fault. Preserved slickensides dip at low angles, indicating predominately strike-slip movement along the Las Positas Fault.

An exploratory trench located south of the main strands of the Las Positas Fault zone produced no evidence for the second strand of the Tesla Fault zone as previously mapped. The second strand of the Tesla Fault is regarded by some investigators as potentially active. The exploratory trench penetrated late Quaternary terrace deposits and it exposed beds of the underlying Plio-Pleistocene Livermore Formation throughout most of its length.

Other faults of potential significance to LLNL have not as yet been investigated in detail. A M $=5.9$ (U.S. Geological Survey) earthquake on the Marsh Creek Fault, a portion of the Greenville Fault zone, and numerous aftershocks provided unquestionable evidence for activity along that fault zone. Additional field studies are planned to better determine the extent of the Greenville Fault zone so that a refined assessment may be made of its maximum magnitude earthquake potential.

Investigations to obtain more data on the extent of the Las Positas Fault zone and its relationship to the postulated Livermore Fault zone are planned, as are studies of an area several kilometers south of LLNL where considerable microseismic activity has been detected.

Additional subsurface exploration within LLNL is being undertaken to assess the possibility of ground failure during a major earthquake; this work will be done concurrent with the planned hydrologic investigation. Appropriate geophysical and age determination studies will be performed in support of future field reconnaissance and exploration.

\section{INTRODUCTION}

\section{OBJECTIVES AND SCOPE OF PROJECT STUDIES}

In April 1979, a project consisting of comprehensive geologic, hydrologic, and seismologic investigations of the Lawrence Livermore National Laboratory (LLNL) site and nearby areas was hegun by LLNL geoscience personnel. This study is being made at the request of LLNL management and is designed to provide an in-depth appraisal of aspects of site and regional geology that bear upon safe operation of LLNL facilities. The area being studied includes the Livermore Valley, the western portion of the Altamont Hills, and the northern margin of the Diablo Range south of LLNL.

Particular emphasis is being placed upon identification and location of faults in the vicinity of the Laboratory and $n$ the development and assessment of geologic and seismologic data bearing on fault activity and motion. Other geologic hazards such as slope stability and the potential for ground failure during a major earthquake are also being assessed. 
Hydrologic studies will concentrate on the locations of aquifers, the transmissive characteristics of materials beneath the LLNL site, and the potential for ground water contamination in the event of a significant on-site spill of radionuclides or toxic chemicals.

The geologic, hydrologic, and seismologic data will serve as technical input to a Final Environmental Impact Report being prepared for LLNL, pursuint to the National Environmental Policy Act. The geologic and seismologic studies will also provide data for improving the design basis earthquake for LLNL. The improved design basis earthquake parameters will in turn be used by LLNL structural engineers as they reevaluate the adequacy of the seismic resistive designs of important Laboratory buildings.

\section{OBJECTIVES ANI) SCOPE OF THIIS REPORT}

The first phase of the LLNL site study has been completed. Although additional major geoscience studies are planned for later 1980 and 198I, investigations to date have yielded significant geologic and geophysical data. Therefore, this report has been prepared in order that the geologic community and the nublic may be made aware of the results of these investigations and LLNL staff plans for future work.

The following studies have been completed and provide the basis for this status report:

- Literature review and site visits.

A thorough review and evaluation of existing geologic, geophysical, and seismic literature pertinent to the LLNL site and vicinity has been completed. A brief field reconnuissance was made of those areas south and east of LLNL where previous geologic studies differ significantly with respect to both data and interpretations.

- Subsurface studies.

All known subsurface data previously obtained for the LLNL site has been collected and evaluated. These data largely consist of exploratory borings made during foundation design studies for major buildings at LLNL.

- Photographic studies.

Three sets of black and white stereoscopic aerial photographs of the LLNL site and vicinity were examined for features potentially indicative of faulting. Photo sets examined include flights in 1940 (scale 1:20,000) and Hights in 1958 and 1972 (scale 1:12,000).

- Geophysical surveys.

Reconnaissance geophysical surveys were made within the LLNL site and vicinity to seek subsurface features that may indicate the presence of faults. An attempt was made to identify and determine the extent of subsurface marker horizons als a means of developing more detaled structural and stratigraphic data.

\section{- Geologic exploration.}

A mujor field investigation was conducted within and near the LLNL site to examine near-surface malerials in areas where previous investigators have postulated faults or where geologic or geophysical studies have identified anomalies suggestive of faults. The field investigation consisted of the excavation and detailed geologic logging of seven exploratory trenches, improvement and mapping of an outcrop along the west bank of the Arroyo Seco within Sandia National Laboratory, Livernore (SNLL) property, and mapping of the Greenville Road sut north of the South Bay Aqueduct. Also, the south and eatst faces of the excavation for additions to LLNL Building 391 were logged in detail. Several adjacent sewer trenches were examined and logs of geologically significant segments were prepared when circumstances permitted.

\section{- Dating of suils.}

Samples of carbonaceous materjals and cutliche were obtained from exploritory trenches and exposures and were evaluated as to suitahility for radiometre dating by established ${ }^{4} \mathrm{C}$ and experimental ${ }^{230} \mathrm{Th} /{ }^{234} \mathrm{U}$ dating method:. Dating of suitable specimens has been smpleted. Geologic interpretations of the dates obtained are presented in this report.

\section{OTHER PROJE(T SITIES}

A seismic monitoring network, consisting of nine stations, has been established and is monitoring the microseismicity of the Livermore $V_{\text {alley }}$ and adjacent areas. At the beginning of the Livermore Valley earthquake sequence on January 24. 1980. four seismic monicoring stations were operative. A fifth station was put into operation on January 25. 1980. These stations provided valuable information 
about the aftershock sequence that followed the January 24, 1980 earthquake. Details of the network operations and seismologic observations made will he discussed in separate project reports. A program for the installation of strong motion instruments in key buildings and at selected free-field sites at LLNL has been planned. Instruments are being procured and will be installed in early 1981.
Planning of the hydrologic investigation has been completed. Installation of monitoring wells and the obtaining of soil samples for determination of hydrologic parameters and nuclear chemistry studies are scheduled to be completed during the second half of 1980 . The results of the hydrologic investigation will be presented in future project reports.

\section{LAWRENCE LIVERMORE NATIONAL LABORATORY SITE}

\section{LOCATION}

The Lawrence Livermore National Labora:ory is located in Sec. 12 (projected). T3S, R.2E, Mt. Diablo Base and Meridian. The Laboratory site is in the southeastern portion of the Livermora Valley a pproximately $65 \mathrm{~km}$ ( $40 \mathrm{mi}$ ) east of San Francisco. The site and its environs are shown on Fig. 1.

\section{PHYSIOGRAPHIC SETTING;}

LLNL has been constructed on a rather smooth land surface that slopes gently downward to the northwest. Elevations within the Laboratory vary from a low of $174 \mathrm{~m}(570 \mathrm{ft})$ at the northwest corner of the site $10206 \mathrm{~m}(675 \mathrm{ft})$ at the southeast corner. Total relief is $32 \mathrm{~m}$ ( $105 \mathrm{ft}$ ) over a distance of $1.9 \mathrm{~km}(6350 \mathrm{ft})$. Siopes on the site are relatively uniform and generally do not exeed three percent. Exceptions are the hanks of the Arroyo Seco Creck channel and the side slopes of various open drainage ditches within LLNL. These slopes averagc about 50 perent. Site lopographic features are shown on Fig. 2.

The southwestern part of LLNL is drained by Arroyo Seco Creck, a minor stream that flows hriefly following major winter storms. The northern and eastern parts of LLNL were originally drained hy the Arroyo Las Positas. However, in 1965. as part uf an erosion control program, the Arroyo Las Pasilas was channeled north to the northeast corner of the stte. and from there west along the north perimeter to an outlet at the northwest corner. This outlet, which also serves as the outlet for the Liboratory's surface drainage system (storm and irrigation), empties into a channel that runs north to the Western Pacific Railroad tracks and then westward to a junction with Arroyo Seco Creek.

Livermure Valley itself is an east-west oriented topographic and structural depression that trends at nearly right angles to the strike of the Central California Coast Ranges within which it is located. The Valley is approximately $25 \mathrm{~km}$ (16 mi) long, east to west, and averages $11 \mathrm{~km}(7 \mathrm{mi})$ in width, north to south. It rises gradually from an approximate elevation of $92 \mathrm{~m}$ ( $300 \mathrm{ft}$ ) at the drainage exit along the Arroyo de Laguna southwest of Pleasanton to an upproximate elevation of $220 \mathrm{~m}$ (725 ft) along its eastern margin.

The relief of the Livermore Valley is slight except for occasional hills, which rise to about $46 \mathrm{~m}$ (150 ft) above the valley Moor. One group of such hills is located about $1 \mathrm{~km}(0.6 \mathrm{mi})$ south of LLNL. A second group of hills is located approximately $3.4 \mathrm{~km}(2 \mathrm{mi})$ northwest of the Laboratory. Geologic studies (Caifornia Department of Water Resuurees, (CDWR) 1966, 1974; Herd, 1977) indicate that some of these hills are results of uplifts of older materials along faults.

The Livermore Valley is drained by westwardllowing intermittent streams. These streams join west of Pleasanton (see Fig. I) to form the southflowing Arroyo de Laguna, a tributary to the Alameda Creck drainage system. Winter flows that are not captured and used for groundwater recharge how out of the valley and eventually reach San Francisco Bay at Union City. by way of Alameda Creek. 


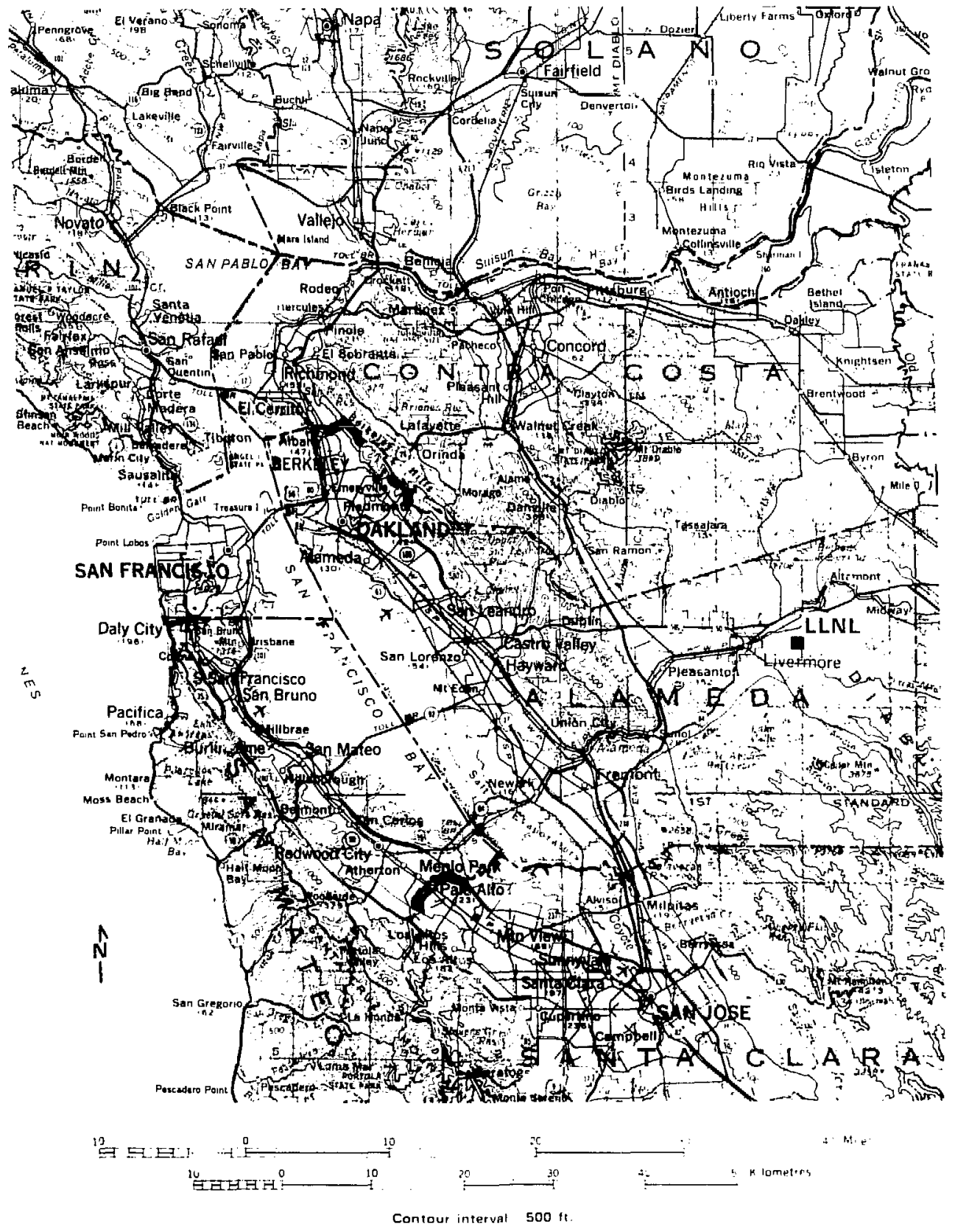

FIG. 1. Location map of Lawrence Livermore National Laboratory (LLNL). 


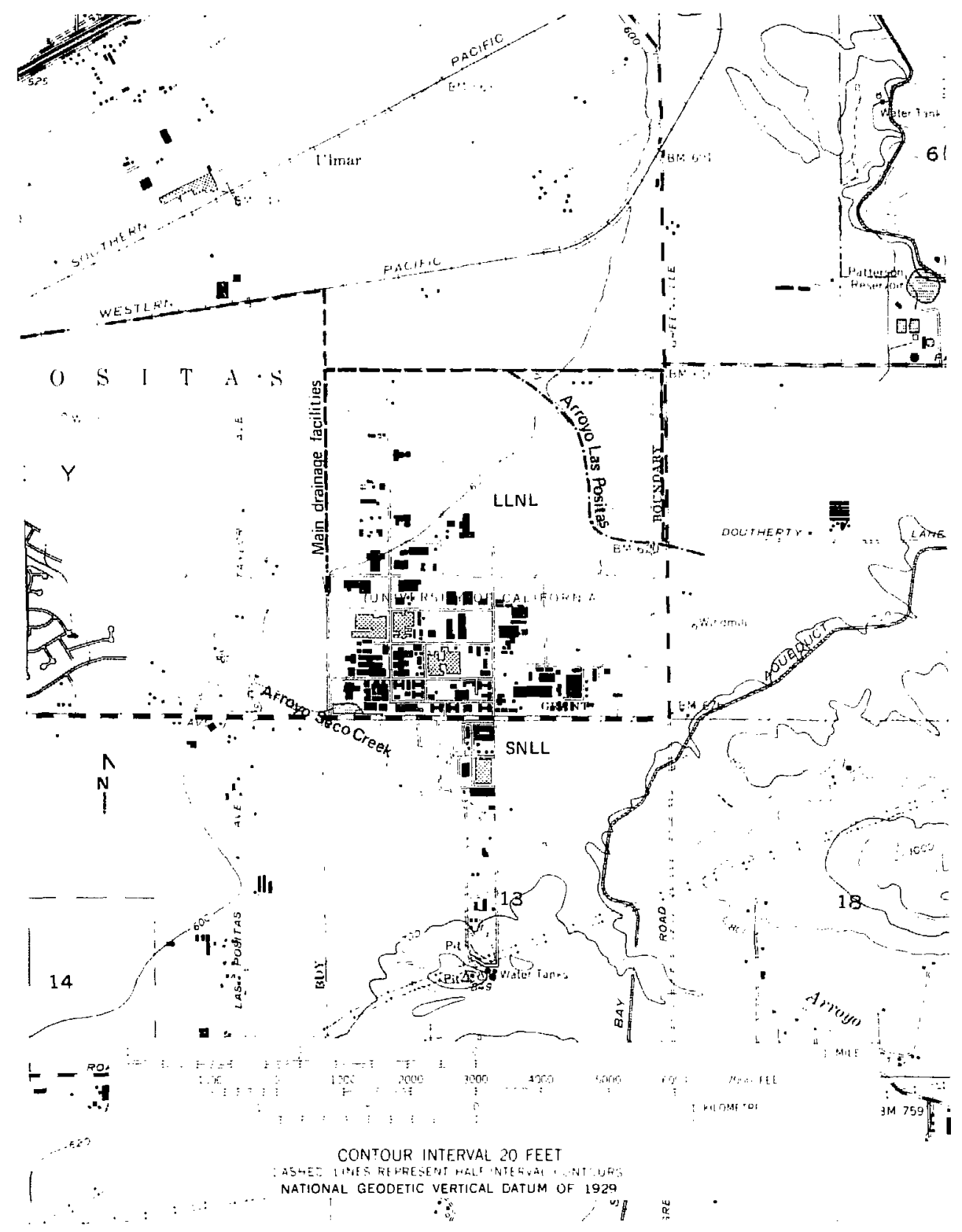

FIG. 2. Topographic setting of LLNL site (from USGS Altamont, CA Quadrangle, 1968 edition). 
The natural Livermore Valley drainage system was originally somewhat restrict-d. Storm runoff periodically overflowed and formed a shallow intermittent lake where northwestern Pleasanton is now located. Near the beginning of the 20th century, the lake was drained to permil agricultural develop- ment, and additional drainage works were later constructed to permit urbanization. An area of enclosed drainage still exists in the northeastern Livermore Valley, where winter stormhows accumulate in an intermitten! pond known as Frick Lake.

\section{GEOLOGIC SETTING}

\section{REGIONAI. GEOLOGY}

The Livermore Villey is located within the California Coast Range Province. The Coust Range Province chiefly consists of a system of sub-parallel mountain ranges and valleys that mostly trend north-northwest. The Livermore Villey itself is an exception; it roughly bisects the Diablo Range as an east-west trending structural basin.

This regional pattern of northwest trending Coast Range relief aligns with the majority of active faults and reflects the regional deformation that the province is experiencing. While many oi the faults are relatively minor and are related to local geology, there are three major fault systems that have been functamental in the history of the province. These are: the San Andreats, the Sur-Nacimiento, and the Coust Range Thrust. 'These fault systems deline: .e three completely different lithologic blocks. As shown in Fig. 3, the Salinian Block lics between the Sur-Nacimiento and the San Andreas faults and is composed primarily of granitic and metamorphic rocks. The second block lies to the east between the San Andreas and the Coast Range Thrust fault and is composed primarily of eugeosynclinal rocks of the Franciscan assemblage. The third block consists of late Mesozoic through late Tertiary marine sedimentary rocks deposited on a complex basement of ancient oceanic and continental crust. This block lies mainly along the eastern margin of the Coast Range province but in places (for instance, the Berkeley Hills west of Livermore Valley) remnants of this block are preserved within the core of the Coast Range province.

The juxtaposition of these three distinct lithologic blocks presents structural and chronologic problems that have not been completely resolved. Many problems arise from the complexity of the Franciscan assemblage and its unusual con-
Lacls with the surrounding rocks. The Franciscan assemblage is a nielange of graywacke, siltstone. shale. chert, limestone, and mafic volcanic rocks and in places has been so deformed as to resenble a megabreccia. However, abutting the Franciscan on the east is the contemporaneous miogeosynclinal Great Valley sequence (of late Mesozoic age) and overlying Tertiary rocks, which are ordered and conformable.

Both the Franeiscan assemblage and the Great Valley sequence consist mainly of marine clastic rocks, but they differ in style of deformation and degree of metamorphism. The origin of the Franciscan assemblage and its lectonic relationship to the Great Valley sequence have long been subjects of controversy. Irwin (1957) and Bailey and others (1964) noted that fauts generally separate the Franciscan from the Great Valley sequence, and th:y suggested that the Franciscan rocks and the Great Villey sequence are juxtaposed along a regional ihrust fault, later named the Coast Range Thrust (Biiley and others, 1970).

Within the last decade, the concept of plate tectonics has revolutionized the interpretaticn of Coust Range geology. According to current theories, the Franciscan assemblage accumulated ir a subduction zone, while the Greal Valley strata accumulated farther east in a fore-arc basin (Hamilton, 1969: Blake and Jones, 1974). The ultramafic and mafic rocks that commonly separate these two sequences represent the oceanic crust and the upper mantle that now lie below the base of the westernmost Great Valley sequence. Probably beginning in the Late Jurassic and continuing into Tertiary time, the Franciscan assemblage was subducted beneath the oceanic crust and the Great Vallcy sequence. The Coust Range Thrust Falult located mainly along the eatstern margin of the Coast Range Province is believed to man the location of the subduction zone. 


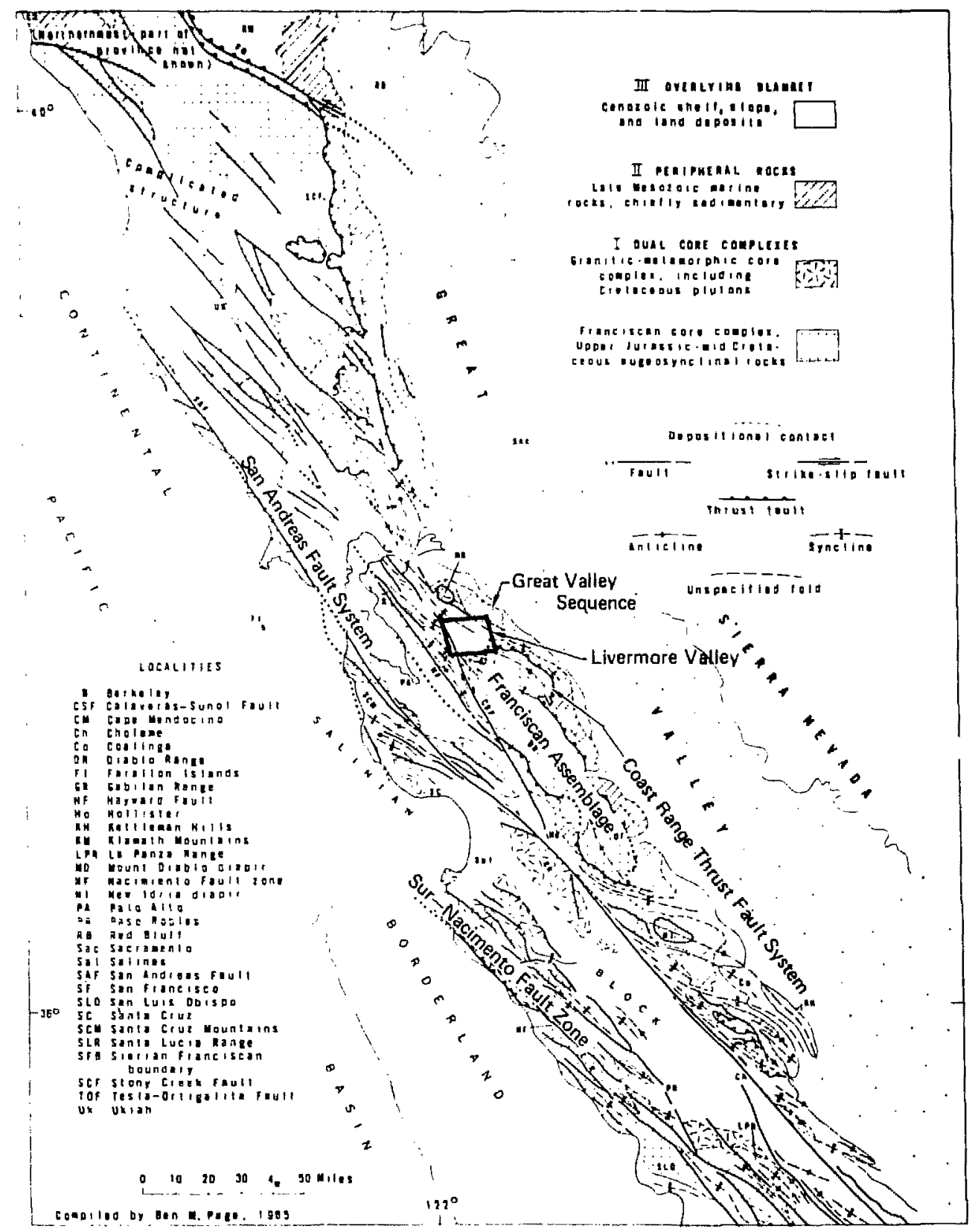

FIG. 3. Structure of the Coast Range Province (modified from Page, 1966). 
The Coast Range Thrust was active primurily between Jurassic and later Teritary time. During that period, the fault was the most significant structural feature in California, marking the active subduction zone between the North American plate and various plates that existed to the west of the North American continent (Page, 1966). Thrust displacements across the fault were measured in many kilométers. During late Tertiary time, changes occurred in regional tectonics and the thrust fault surface was warped, folded, and sheared, consequently developing a complex en cchelon fault system (Bailey and others, 1970). The Greenville, Teslit. and Ortigalita Fault zones, locited along the eastern margin of the Livermore Valley, are nortions of this en-echelon fault system and are periodically active, as evidenced by the Livermore Valley earthquake sequence that began on January 24, 1980 (Cockerham and others, 1980).

Meanwhile, at great depth within the subduction zone, the Franciscan was sucessively metamorphosed and was then freriodically returned to the surface (Ernst, 1971). Tiis model accounts for the different deformation styles and metamorphic assemblages in the Franciscan Complex and Great Valley sequence.

In the Central California area, active subduction continued into Cenozoic tine. The Pacific Ocean at that time extended inland to the foothills of the Sierra Nevida and a continental shelf that extended offshore included a large part of the present day Great Valley and some portions of the area where the Coast Ranges now stand. During most of the Cenozoic era, tectonic movements produced four cycles of marine deposition that are clearly recorded in the Paltocene to Miocene rocks of the Sacramento Valley region (Almgren, 1978). Rocks correlative with those in the Sacramento Valley region occur in the Altamont Hills east and southeast of LLNL. The Altamont Hills areat has been highly disturbed by movements along faults that are descendants of the ancient Coast Range Thrust fault zone. The pattern of marine sedimentation is thought to have come to an end in Miocene time (roughly 15 million years ago) when right lateral plate boundary movement began along the San Andreas Fault system (Sullivan and Waters, 1980).

The San Andreas Fault and its associated branches are the best known geologic features of the
Coast Range Province. The fault system extends at least $1200 \mathrm{~km}(750 \mathrm{mi})$ from near the Mexican border north to Shelter Cove, California (Wesson and others, 1975). Based upon a paleogeographical reconstruction of the depositional site of the Cantua Sandsıone (Nilsen, 1979), approximately $305 \mathrm{~km}$ (190 mi) of post Eocene right lateral displacement has occurred along the San Andreas Faull. Activity continues today along this major fault system.

Extensive Qualernary activity has led to the formation of a series of valleys along the entire length of the San Andreas Fault. Within these valleys, which vary in width from hundreds to thousands of feet, is a zone of breceiated rocks. The San Andreas Fault cannot be traced as a single strand through this zone: surface rupture usually occurs discontinuously across en echelon faults. Frequently, as a result of local stress concentratic s or other factors, faults will branch off the main fitult system and form subsidiary fault zones.

The geologic conditions in the region around Hollister are apparently conducive to branching: several significant branch faults diverge from the San Andreas in this area. Two of the must signifieant branches are the Hayward Fault zone and the Calaveras Fault zone (Fig. 4). Both of these faults ire among the longest in the state. They disappear beneath the waters of San Francisco Bay and alluvial cover in the San Ramon Valley, respectively. During the 19th Century both lauls generated large earthquakes. and both are presently readjusting to stress by creeping. Block lautting hetween the Hayward and Calaveras Faults gave rise to the impressive horst structure of Sunol Ridge west of the Livermore Valley.

Generally, the basement rocks between the San Andreas and the Coast Range Thrust Fault systems are Francisean. In the region of Livermore, this areal of Franciscan rocks is called the Diablo Antiform. The Diablo Antiform is a topographic and struetural high that has been complexly folded and faluted. The Diablo Antifornt is seismically active and monitoring by the U.S. Geological Survey during the period of 1969-1979 has defined several tight clusters of seismicity within the Antiform imbedded in a dirfuse background of activity (Ellsworth and Marks, 1980).

As nuted previously, the Livernwore Valle itself is an exception to the general pattern of Coast Range geology. It is a structural and topographic 


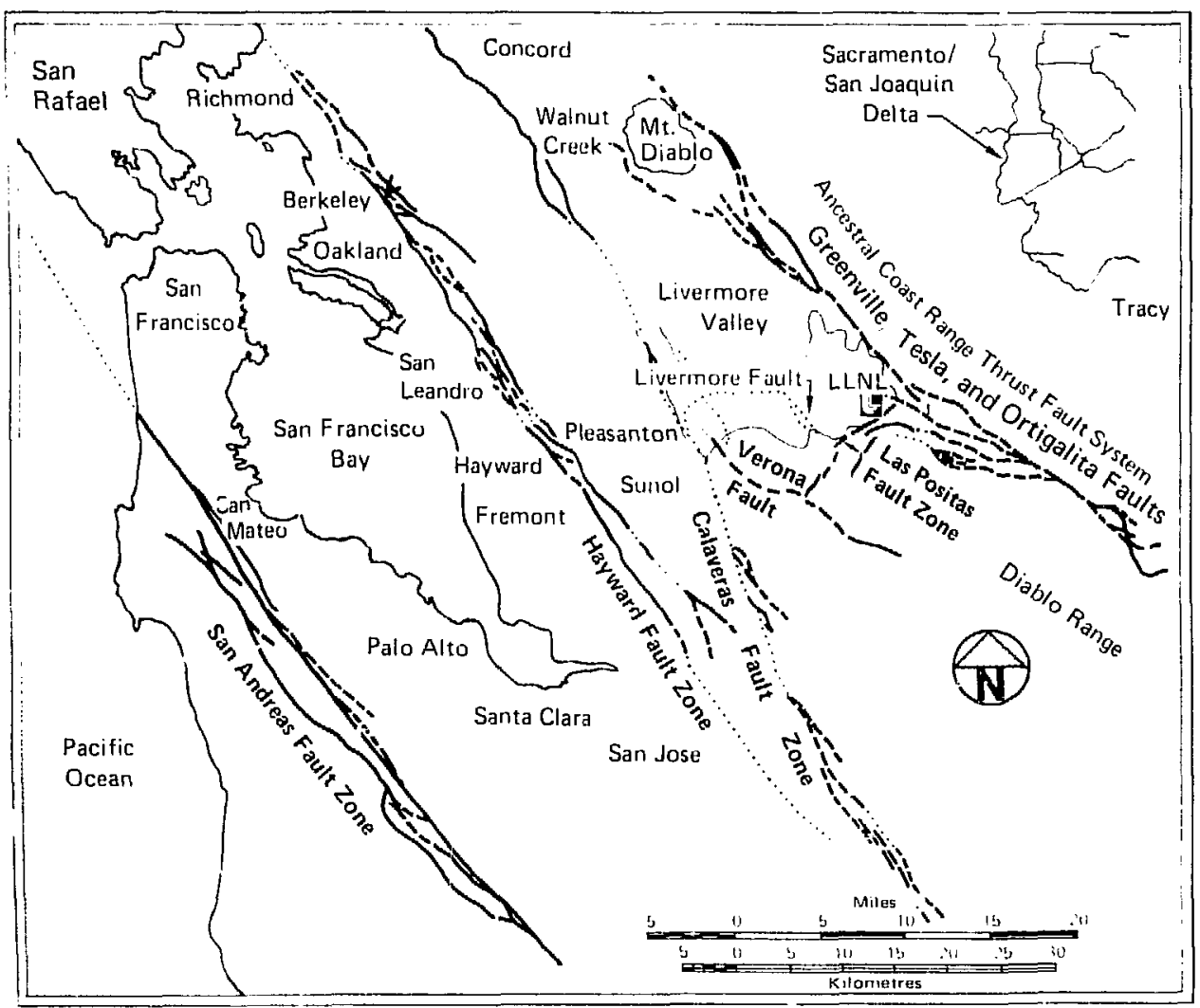

FIG. 4. Major fault zones of the San Francisco Bay area. The great San Andreas zone, lying to the west of the Bay, is one of the chief tectonic features of the earth. It is capable of very strong earthquakes-ror exanıple, the San Francisco earthquake of 1906, of magnitude 8.3. The Hayward and Calaveras zones, lying between the Livermore Valley and the Bay, are parts of the San Andreas system, branching off from the main fault some distance south of the Bay. These faults, too, are active and have produced strong earthquakes, probably up to magnitude 7.5. The Greenville, Tesla and Ortigalita Faults, loceted to the east of LLNL, may be remnants of the Coast Range Thrust Fault. The Livermore Valley earthquake sequence that began on January 24, 1980 gives evidence that these faults are periodically active. The Verona, Livermore, and Las Positas Faults are additional elements in Livermore Valley geology, although their tectonic significance is uncertain. 
low area trending at nearly right angles to the regional grain. The Valley is filled with several thousand feet of young, largely continental, sedimentary deposits (CDWR, 1966) and includes northeast as well as northwest trending tectonic features (Herd, 1977).

\section{GEOLOGY OF LIVERMORE VALLEY AND ADJACENT AREAS}

\section{Previous Studies}

Early geologic work in the Livermore Valley and adjacent areas was performed by $A$. Huey (1948). Huey mapped the geology of the Tesla 15-minute quadrangle, and he traced and named a number of strands of the Tesla-Ortigalita Fault system in the hills east and southeast of LLNL. Geology as mapped by Huey is shown in Fig. 5.

In 1966, CDWR evaluated the geohydrology of the Livernore and Sunol Valleys. Their work incl dded an appraisal of regional geology, including fauit locations. The study identified a number of ground water barriers that were believed to be the results of fault displacements. In 1974 CDWR made some revisions and extensions to their previous work. The Department's 1974 geologic map of the eastern Livermore Valley is shown in Fig. 6.

In 1971, John A. Blume and Associates (Blume) prepared a geotechnical investigation report concerning additions to the LLNL Plutonium Handling Facility, Bidg. 332. This study drew largely upon existing CDWR data but included excavation of an exploratory trench east of Bidg. 332. Inspection of the trench revealed no feature suggestive of faulting.

In 1972, Blume was retained by LLNL to investigate faulting at and near the LLNL site. In the Blume report (Blume, 1972), Huey provided background geologic information. Huey extrapolated several of his previously mapped faults from the hills into the Livermore Valley. These were the Greenville, Carnegie, Corral Hollow, and Tesia Faults.

Blume perfornter gravity, magnetometer, and seismic refraction studies in an cffort to locate faults extrapolated by Huey. They also reviewed geodetic leveling data to detect ground movements within the: Livermore Valley. The study did not include exploratory trenching or drilling within LLNL. although a utility trench excavated in Sec. 13, T3S, R2E was inspected for evidence of faulting.

On the basis of its investigations, Blume added strands 2 and 3 of the Tesla Fault, the Ramp Thrust Fault, and the Doutherty Fault to Valley geology. Blume concluded that west of Greenville Road and southeast of the Laboratory there was no geophysical evidence for the Corral Hollow Fault that had been previously projected across LLNL. Fault locations as postulated by Blume (1972) are shown in Fig. 7, Blume (1972) also produced geologic cross section A-A' (for location, see Fig. 7) based on interpretations of well data. This cross section is shown in Fig. 8.

In 1977, D. Herd, U.S. Geologic Survey (USGS), published a new geologic map based largely on airphoto interpretation. Herd introduced a new element into Valley geology, a northeast trending fault zone located in the southern and southeastern portions of the Livermore Valley. Herd named this feature the Las Positas Fault Zone. The Las Positas Fault zone is of particular interest in that its trend is at almost right angles to the previously recognized fault pattern.

Herd's study showed no strands of the Tesla Fault Zone as projected northwest by Huey (Blume, 1972). In contrast, Herd considered the Tesla to be a part of the Greenville Fault Zone and showed the two faults merging in the NE I/4 Sec. 34, T3S, R3E. Herd's interpretation of the fault pattern near LLNL is shown in Fig. 9. He also reinterpreted the well vata used by Blume (1972) and created a modified cross section as shown in Fig. 8.

In 1978, URS/Blume and Associates (URS Blume) did a field study for SNLL. URS/Blume"s general picture of the faulting changed little except that the Tesla 3 fault was removed and the Tesla 2 wis moved slightly. URS/Blume stated that they were unable to confirm the presence of the Las Positas Fault identified by Herd. However. they observed features in several of their exploratory trenches that could be interpreted as having been caused by faulting. Faulting as interpreted in 1978 by URS/Blume is shown in Fig. 8 and Fig. 10.

In July 1979 the CDWR releised a geologic study that included an assessment of the seismic safety of Patterson Reservoir, Del Valle Dam, and Lake Del Valle. The 1979 CDWR study was based upon review of previous reports, field checking and reconnaissance mapping, reexamination of preconstruction exploration and construction records, and a limited trenching program. 


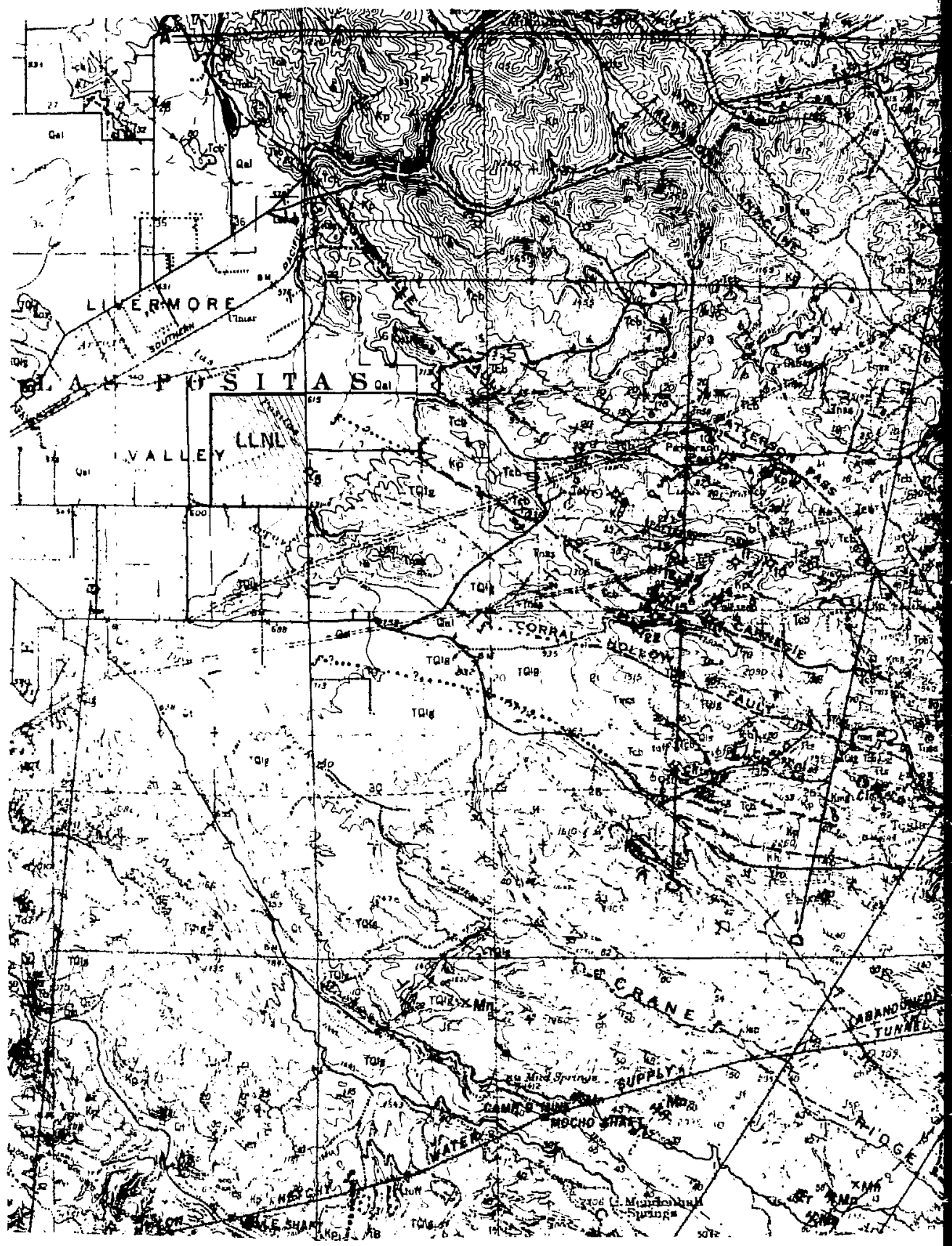

FIG. 5. Geology and faulting in the eastern end of the Livermore Valley, as originally mapped by $\mathrm{A} . \mathrm{S}$. Huey in the 1930s (Huey, 1948). Faults are dashed where inferred, dotted where extrapolated. 


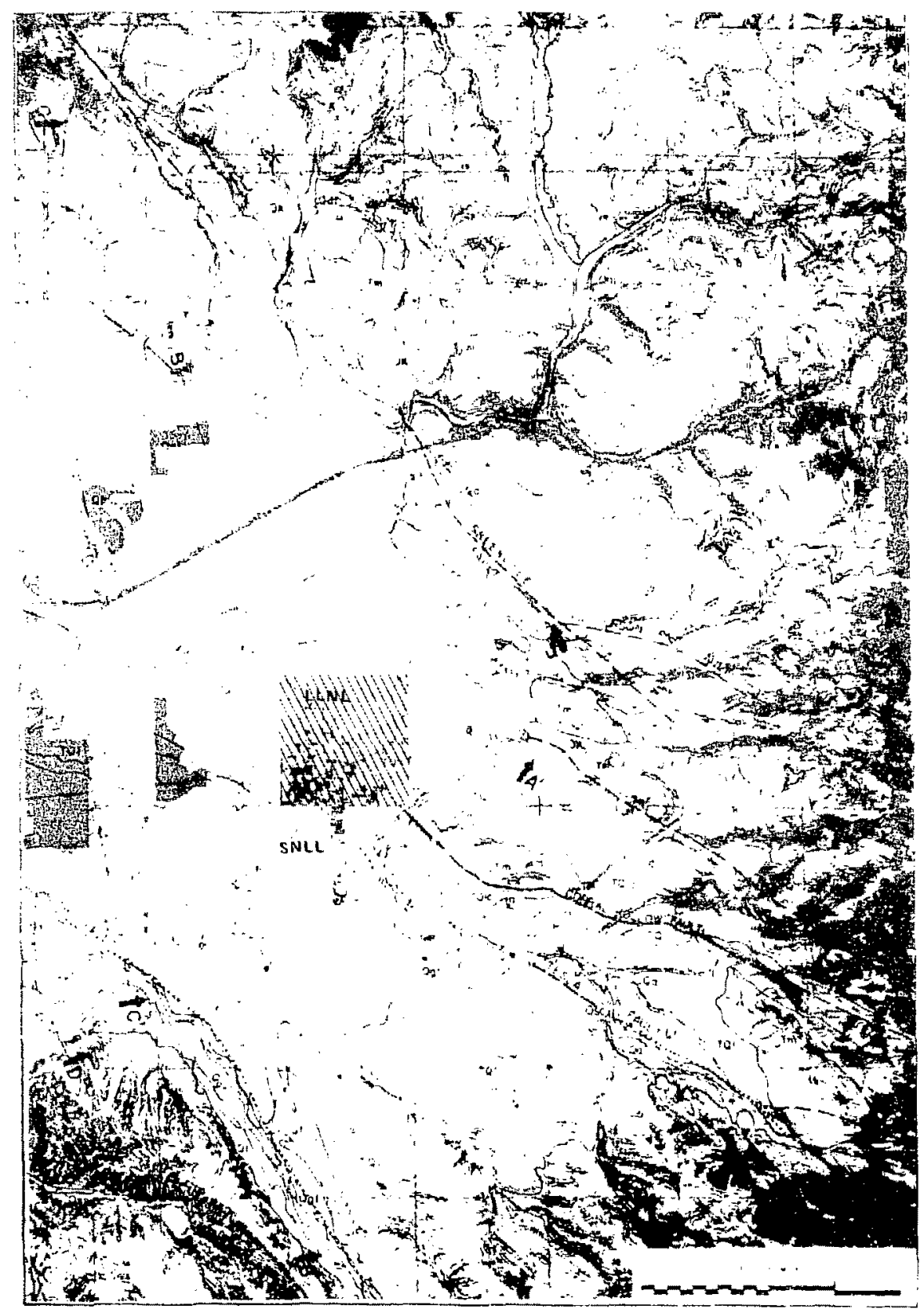

FIG, 6. Ceulogic map of southeastern livermore I alley (CII) R. 1974). 


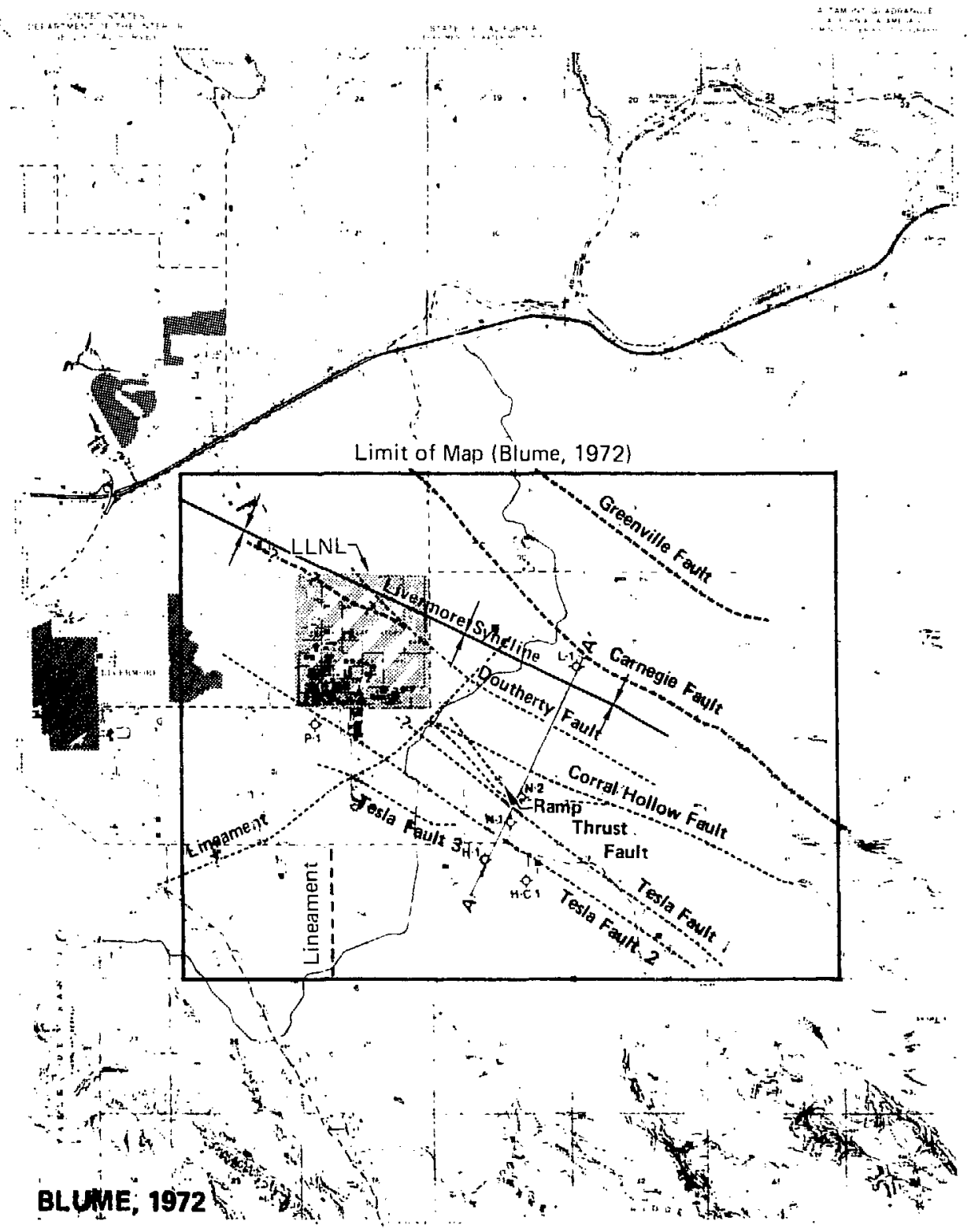

FI( . 7. Folding and faulting as mapped by Blume (1972). (ross section A-A' is shown in Fig. 8 . 

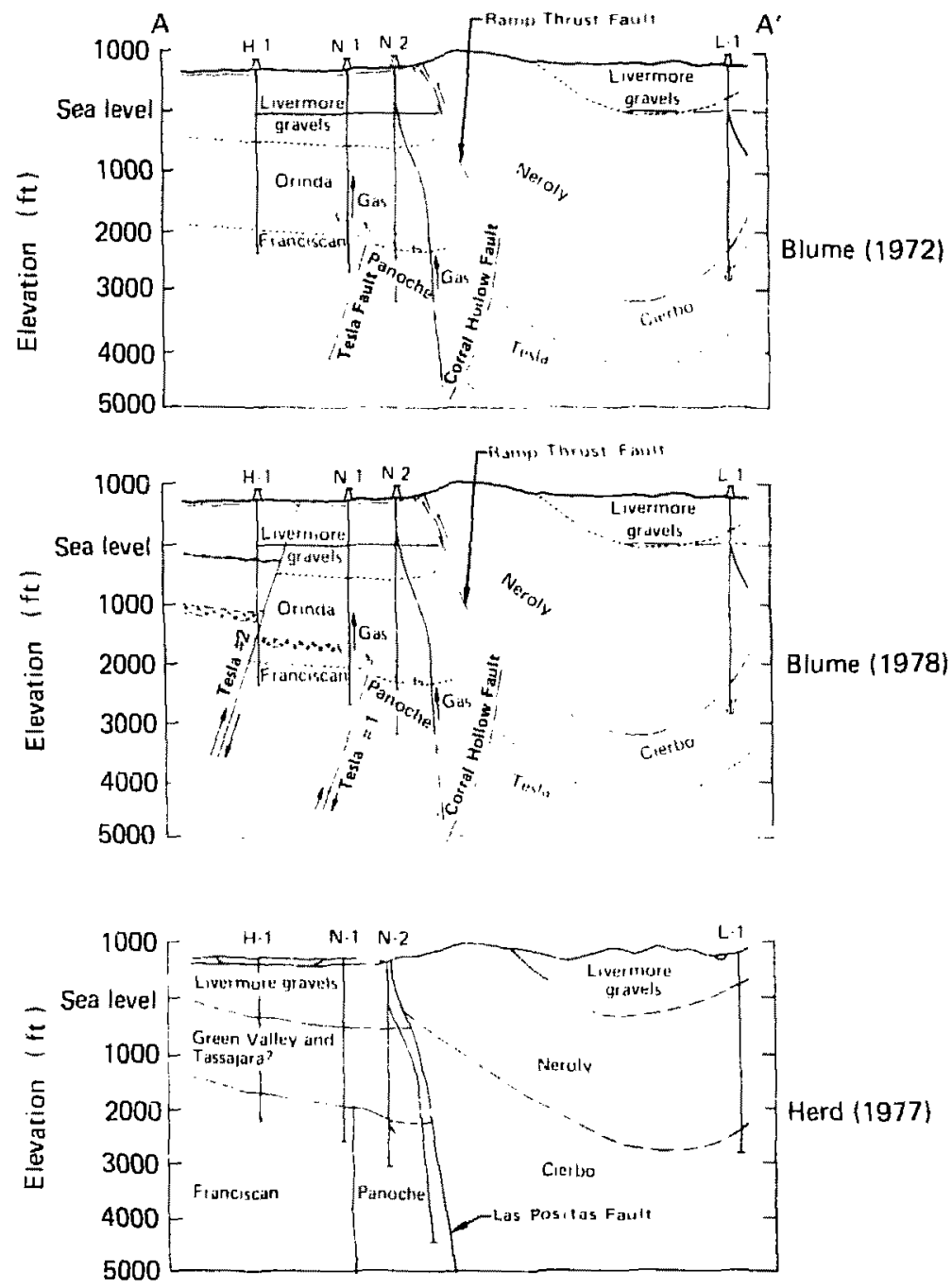

FIG. 8. Section A-A', as shown in Blume (1972), in Blume (1978), and in Herd (1977). At a depth of about 2000 ff below sea level, between wells N-1 and N-2, the sections show a contact of the Franciscan and Panoche formations, which implies a relative displacement between the two of $5000 \mathrm{to} 10000 \mathrm{ft}$. Such a displacement is usually interpreted as evidence of a fault. Blume (1972) identifies it as the Tesla Fault. The evidence from these same two wells, however, also shows that this contact is overlain by sands, gravels, and clays that have been undisturbed at least since the beginning of the Pleistocene epoch, more than a million years ago. Such a long period of dormancy suggests that the fault, if there is one, is inactive. Comparing Blume's 1972 and 1978 sections, one sees that Tesla Fault 2 has been introduced into the latter, and that the structure around well $\mathrm{H}-1$ has been changed. Blume (1978) cites no new evidence, and an examination of the well logs by LLNL staff shows no reason for the change. Herd (1977) interprets the data near well H-I essentially as originally interpreted by Blume (1972). 


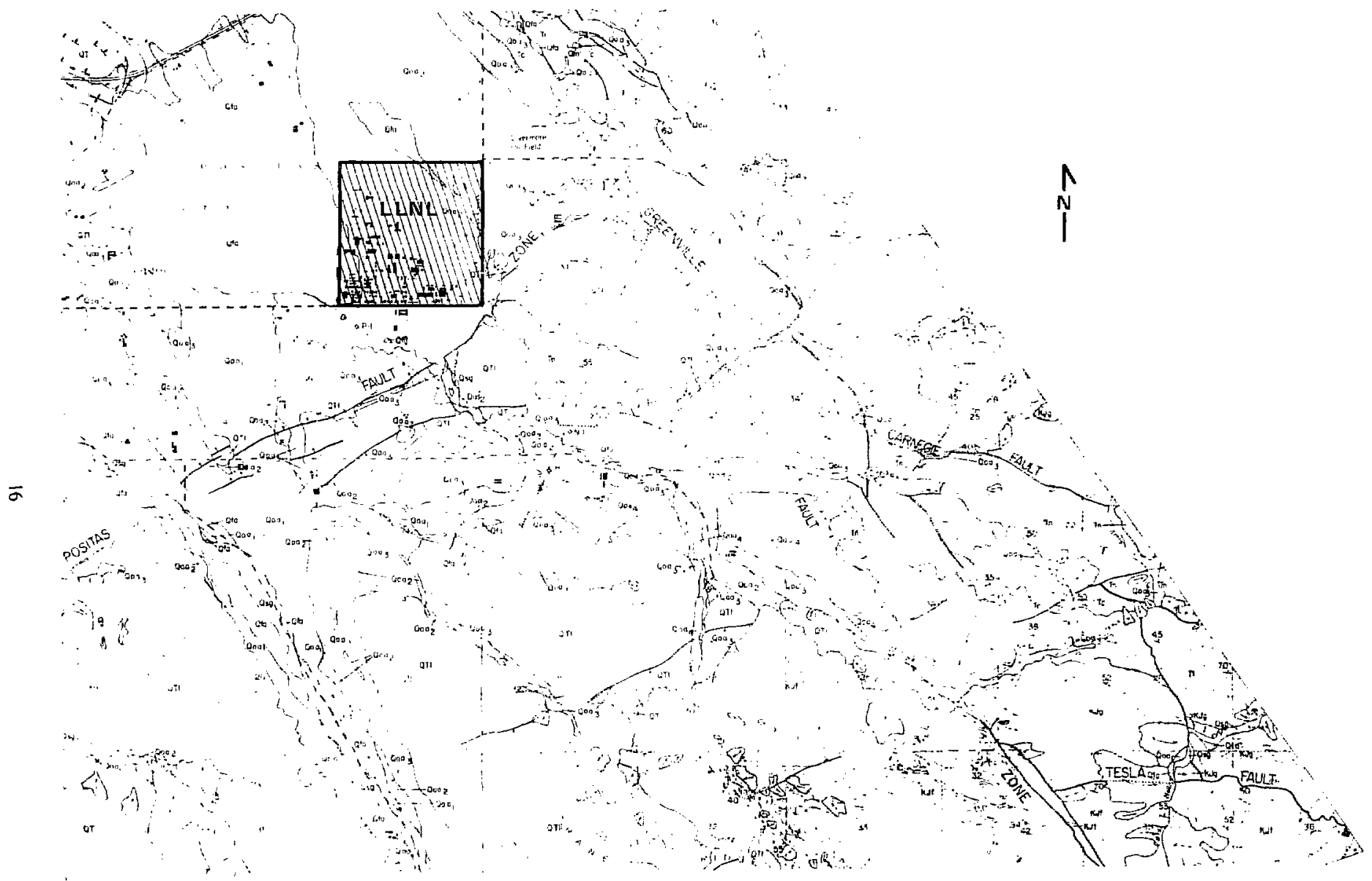

FIG. 9. Geology and faulting as mapped by Herd (1977). An essential difference from Huey and Blume is the replacing of the northwest-southeast trending strands of the Tesla system by southwest-northeast trending strands of the Las Positas zone in the region south of the LLNL site. Herd 's interpretation of geologic cross section A-A' is shown in Fig. 8. 


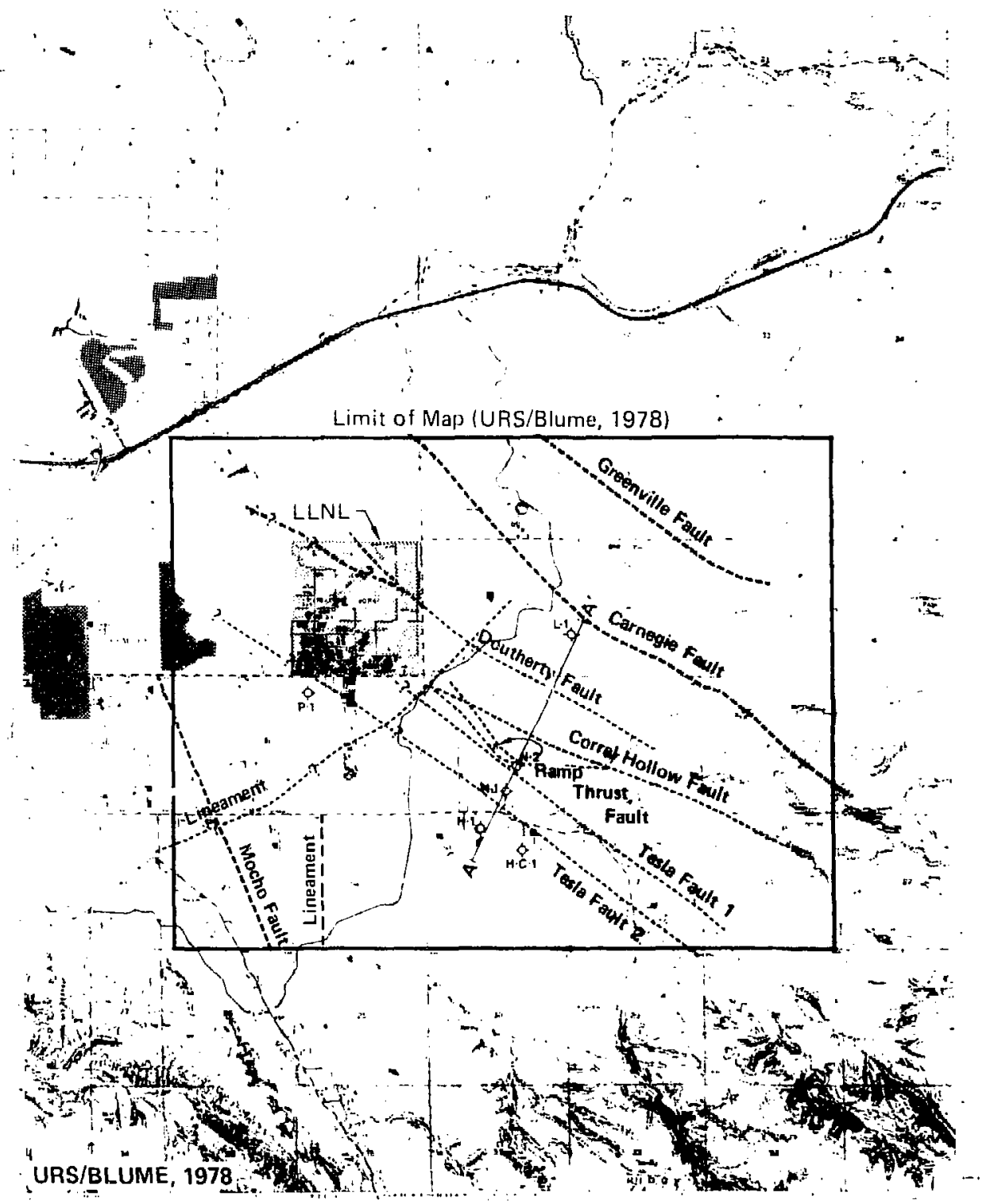

FIG. 10. Faulting as mapped in Blume (1978). Except for the deletion of Tesla Fault 3 and a slight relocation and questioning of Tesla Fault 2, this map is essentially the same as Fig. 7. Blume's 1978 interpretution of geologic cruss section $A-A^{\prime}$ is shown on Fig. 8. 
The 1979 investigatlori resulted in a fault patitern generally similar to previous CDWR studies hut with some modifications. The CDWR recognized the northeast trending Las Positas Fault hut restricted its extent to the area between the Arrovo Mocho on the southwest and the Arrovo Seco on the northeust (that is, only the central portion of the fasult ane shown in Fig. 9). The CDIVR mapped the Livermore falul northwest ateross the centrul portion of the Livermore Valley, hased on dalla from exploratory trenches near Del Valle Dam and on an analysis of waller-well data from the Livermore area. The 1979 CDWR inlerpretation al faulting near L.LNl. w shown in lig. 11.

In biew of the exsung, often contradaturs. gevologle studies to date. at detated reilssessment if the geology in the vionity of LLNL is required in provide adeyuate informatton for a Final Environmental lmpact Statement astd a permil improsement of the design basis carthquake for LLNL ficcilitics.

\section{Sitratigraphy}

fieneral. Sirittigraphic unte expereed in the Livermore Valles and adjacen areis mas he diw cused in terms of three general groupings. These itre:

1. A complex of geneour and melamurphic rock, mapped ats the (Juratsic and Crelaceoun) I ranciscatn assemblage.

2. A sequence of promarils marne, sedmentars rock of Cretaceous through bate Terlats age

3. Promarily contunental racks and allusial deposits of latest Tertiars through Holocene age Each of these groupings will be discussed in following subsections.

As discussed previously under Regional Geolugy, rocks of the Franciscan assemblage and the carlier portions of the Creticeous through later Tertiary sedimentary sequence are equivalent in age but were deposited in differing lectonic environments and appear to have heen juxtanosed by move. ments along the Coast Range Thrust Fault system.

A generalied stratigraphic section fis the Tesia 15-minate quadrangle wis putished hy Hues (1948). and is reproduced an a modified form as Fig. 12. Brief deseriptions of the formations described by Huey will he provided in following paragraphs. Additional subdivisions of Quaternars geoluge hase heen proposed by Helley and others (1972':!n-1 Herd (1977); they will also be described below.

Jurassic and Cretaceous Igneous and Metamorphic Rocks. The basement rocks in the Livermore Valley region are the Francisean assemblage of Jurassic and Cretaceous age. These rocks are ex. posed throughout the entire suuthern part of the Diahlo Range: exposures wend norih wa Sec 29. T3S, R2E about $5 \mathrm{~km}(3 \mathrm{ml})$ suchtheas of $1.1 \mathrm{Nl}$

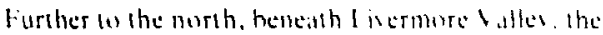

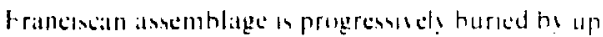

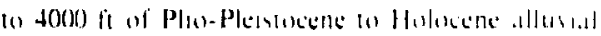

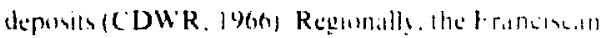

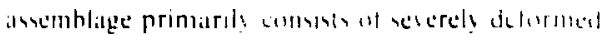
and folded grats actie. whals, and chere Howeser.

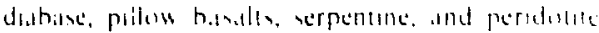
(nceur locall! (Hat) 1946).

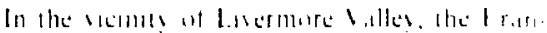

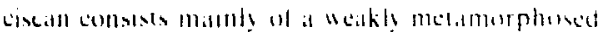

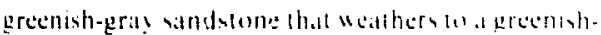

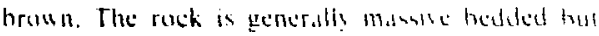
hyghis jointed and forme :rrepulat blash, in ente

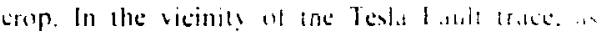

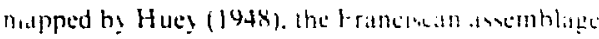
is perratsicely sheared. On the rellugthan Rameh it Set. 28. T3S. R3E. the formatun w chert.

(retaceous-late Tertiar! Warine hedimentars

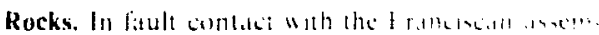

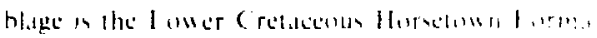

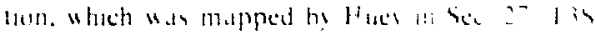

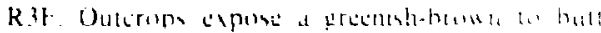

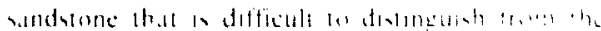

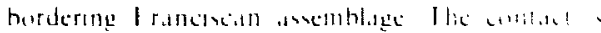
thus usiertan

The Horsctumn formatloun is orertath bs the upper Cretasecous Panoche Formatuon (Hue!. 1948). The Panciche Formatsun an widely cepowed in the Livermare area and is relered wa more recent reports as the (ireat Valle! veyuente (Herd, ly-7. (DWR. 1979). Regionally the Panoche Formattim typically consists of variably cemented. hrom n, cont cretionary sandstons interbedded whth dark ger.s! shale and accasional conglomeratc. Howerer, in the

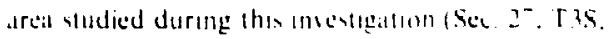

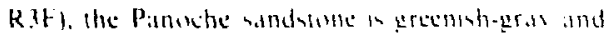

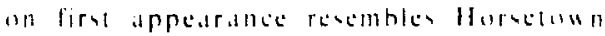

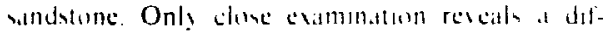
ferent meneralogy. The presence of frable whate in the Pancethe formation also helps to differemalate betweer these ano unts. However, there is a 


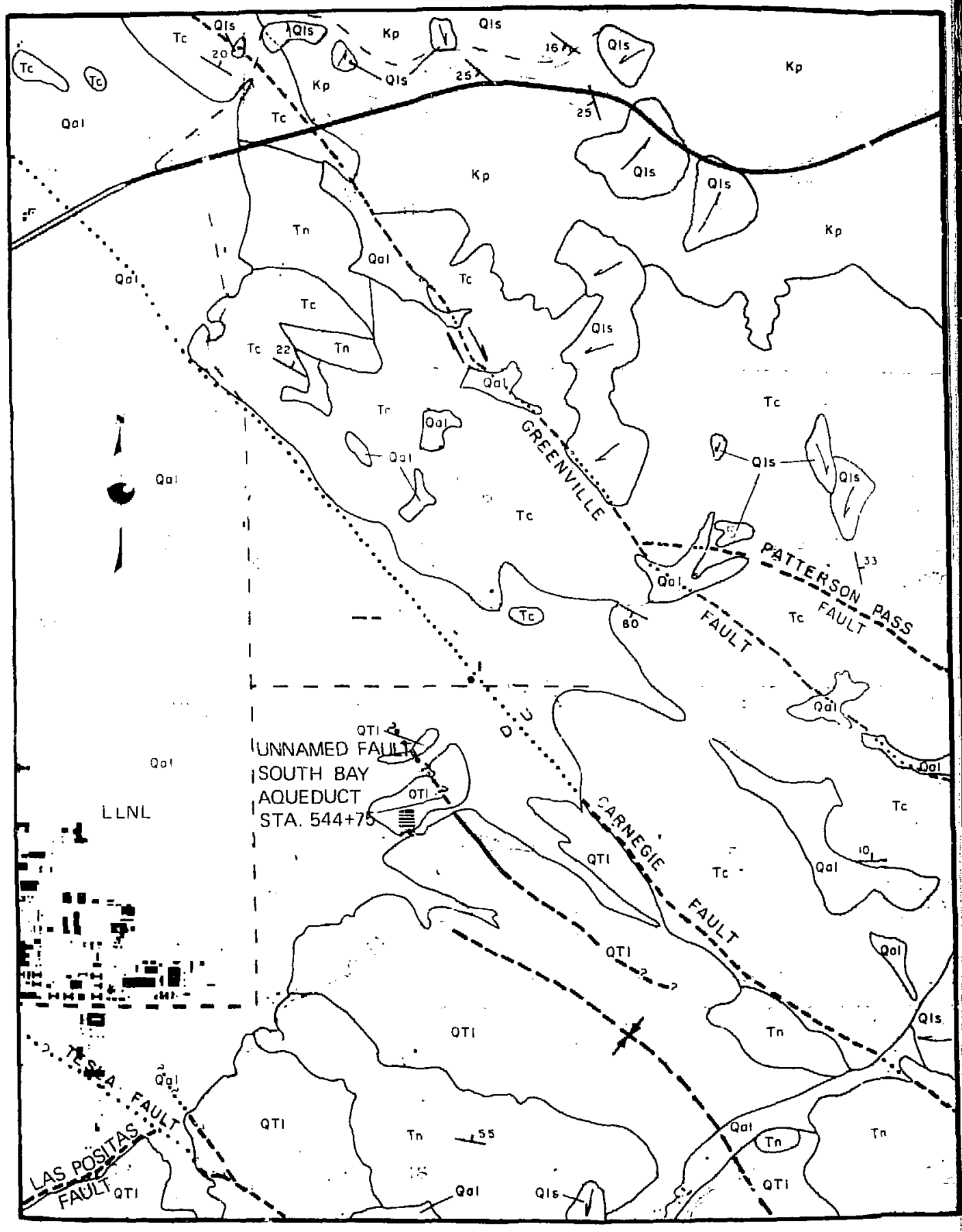



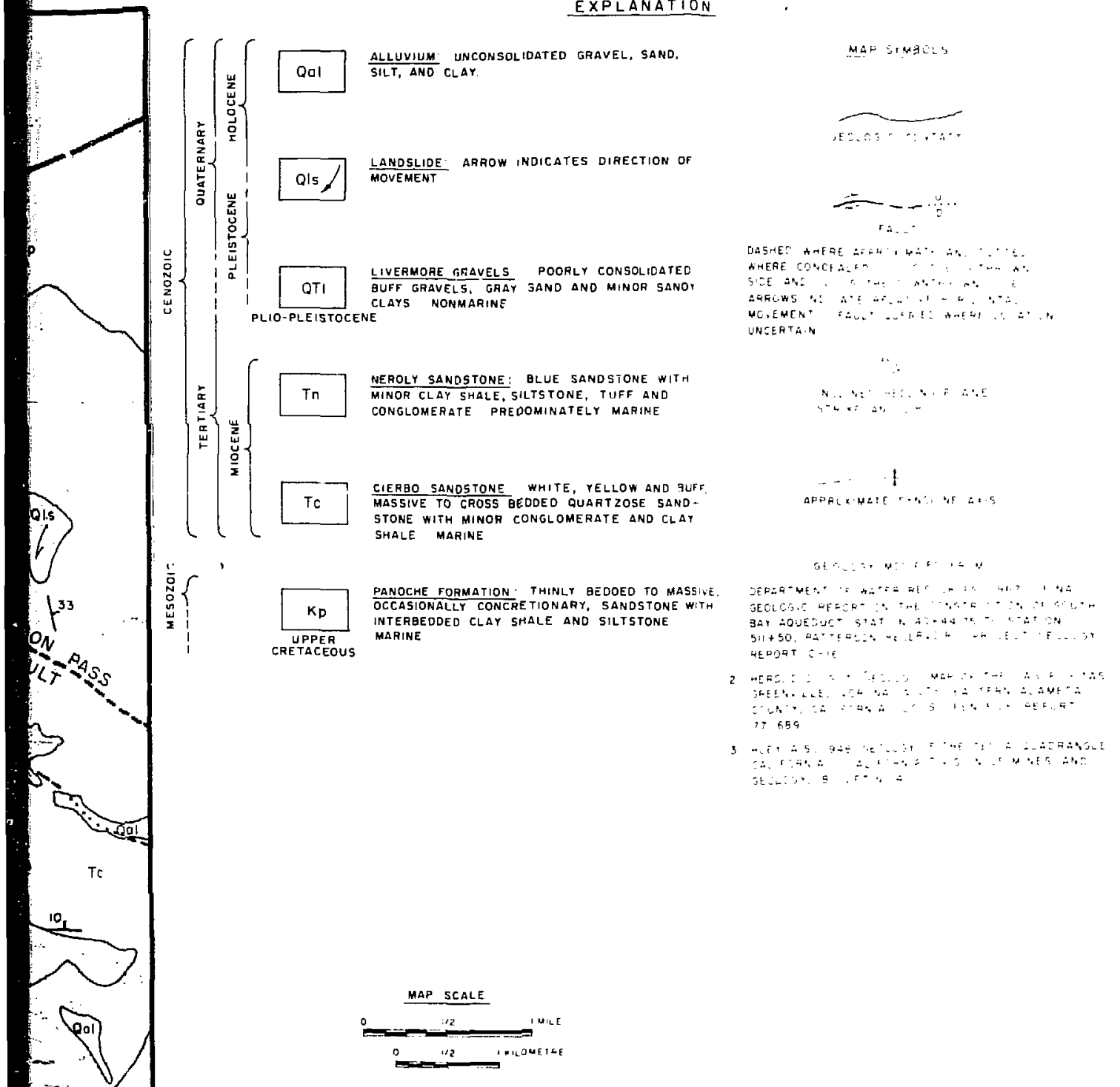

FIC. I1. Cieologs of Patterson reservoir and vicinity (CDWR. 1979). 


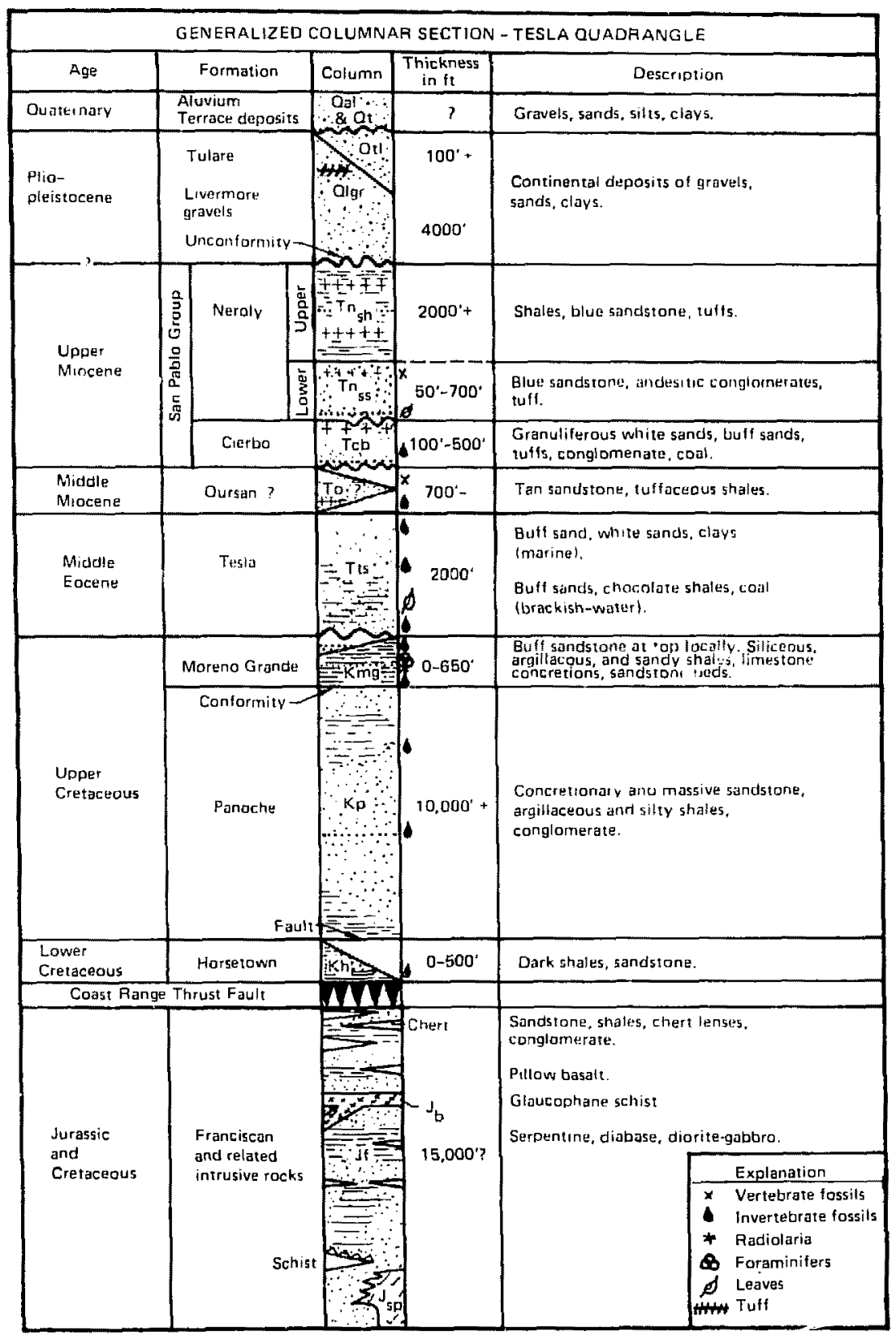

FIG. 12. Stratigraphic column for Livermore Valley (modified from Huey, 1948). 
problem in differemtial:ng the Horsctum nand Panoche Formations in areats devold of outcrop hecaluse of similar appearing float.

Hues (1948) mapped the late Cretilcesus Moreno Grande Formation that werlie the Panoche Formation in a band extending southean from Sec. 27, T3S. R3E w Sec. 33, T35. R+tE. The Moreno Grande Formaluen conswe dominanly of dark sliceous, argillacesus, and sinds strilte with sume limestone cuntretions and fribinte sandatone interbeds. The cormattion in lypically pourly 心pused.

The Eocene Teslat Furmatton, which forms the bitse of the Tertiar! sequence, is expresed in al natrom hand along Tesla Road whete numereth diggings provide excellem erporures. The and is charalelereded hy a white-ll-buff quarl silnd that lask, hedding. Altitudw in the lormation are thus rars'

The Miocene Cierha Formation uncontermathly merlien the Teshit Furmation and is well exposed along Patterson Pass Road (Sec. 9. T2S, R.3E). It consists of pewrly consolidated white-lo-bulf sands with iron-oxide filled fractures. A lithology similar to the Tesla Formation makes separation difficult in areas of deep soil cover. Howe"dr. resistant conglomerate heds and fossils in the formation aid in Iratung this unit.

The Neroly Formatlin nertics the Corba formation. This unit is vers distinctice, comsistung mainly of a hluish sandstone with lenses of andeste heirme songloillerule, and minor lut and tulfacense hale heds. The unis in easily mappable

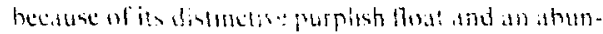

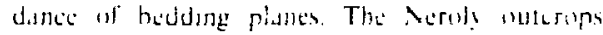
matinls allong and norsh of Corral Hollow Roid, 5 to If $\mathrm{km}(3 \mathrm{l}$ (1) 9 ini) southeil.t of LL.VL, where $1 \mathrm{t}$ is preserved in at fillated sy nchene bordered to the north and south hy the Cierha Formation. Some new ranch reads in this areat and wo the northwest hase exposed bedrock: these exposure. reneal that the formation contilets are locilly diflerent from thuse shown by previous mappers.

Iate Tertiary to Holocene Sediments. Lticrmore Valles is a lopographic and structural depres-

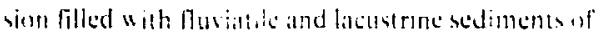
Plin-Pleislocent and Helocente atge (CDWR, 19ho: Blume. 1972). The wat thichness of these depomits

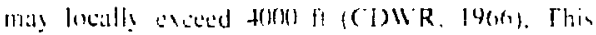
thick sedimentary sequenci has hen subdisided into the Plio-Pleistocenc Livermore Formation and undifferentiated late Pleistucene to Holocene itluvium (ibid.). The subsurface houndary beancen the two units cannot be clearly established because of similarities of the two deposits, which consist of complex assemblagess of gravel, sand. silt. and clas. More recently, other insestigators hase proposed further suthdivisions. partcularly for the latle

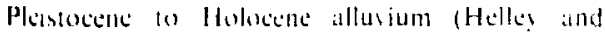
whers, 1972; Heid, 1977).

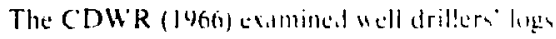

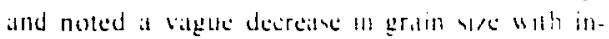
ertining dipth. The CDWR aggented th.th the decreitse of gratin side mat mark the cuntate betheen the Lisermure formation and the Quater

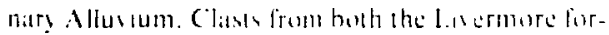

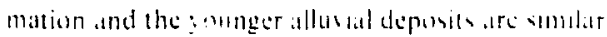

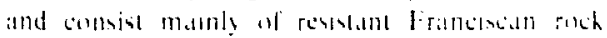

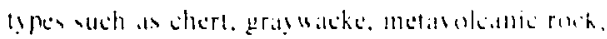
and yuartate. Other Cretalceus and Tertlary rocks dexcribed in the presious sectum are gemeralls pourly cemented and are mot presersed, at least an the courser fratcions.

The CDWR (1466) did nut mitialls repurt ans distinet areal sariations in the compositum of the Lisermore Formation beneillo the l.1sermure

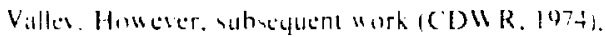

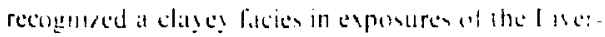

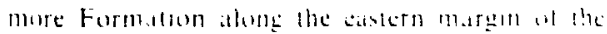
Vitlles. Herd $(1977)$ matpled the sallne areat hut di, nut idenlife ans subduman,

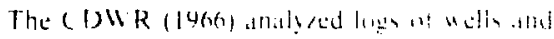

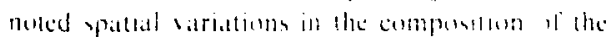

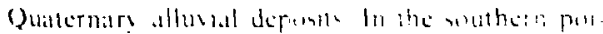

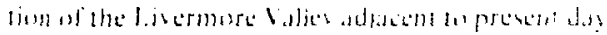

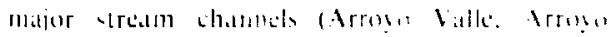
M.xho), the Quatternary alluvial depusts comats dominantly of sand and gratvel. This purtion of the Vitley is a mitgor grounduster retherge ascis (Alameda County Planning Departme-111. 1474)

Sllusial deposit along the northern margen of the valley are dominantly line-graned and repre. sent depusition from small stream draining from the hills north and sist of the Valle! These stream, carrs sediments deried by watherng and cromen

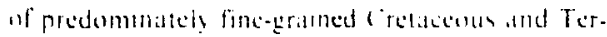

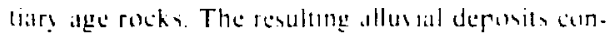

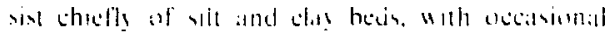
lemw and strongers of simd and grats (CDWR. 19(6). 
In the eastern portion of the Livermore Valfey, well loges show that the alluvium is composed of in. terfingering deposits of grasel, sand, silt, and clay. Individual laygers are lypically not extensive enough to permit correlations between wells. The heterogeneous nature of the alluvium is largely the result of deposition from many small streams (CDWR. 1966).

In the western hatf of the Livermore Valley, extensive gravel lavers deposited by ancestral Arroyo Del Ville alternate with thick claty beds deposiled when lakes were present in the area. These lakes appear to have formed ats a result of periodic interference with Valles drainage, probahly related to movements un the Calateras Fault Zune (CDWR, 1966).

The thickness af the Holocene purtion of the Quaternary allusial sequence is uncertain. The CDWR (1974) estimated that frem a few leet up (1) 200) $\mathrm{ft}$ of Holocerse allusium mat underlie various parts of the Valles and hat the Holocene alluvium is thickest in the western portion of the Livermore Valley:

A ${ }^{4} \mathrm{C}$ age of $5100 \pm 200$ yr was obtained from a sample laken it at depth of about $18 \mathrm{ft}$ in the Arroyo Mecho fleod control shannel north of Pleasanton (Burkland and Assuciates, 1975a, 1975b). The sample was obtained from fine-grained sediments deposiced in the former playa lake areas. If the rate of sedimentition indicated by the age of the ${ }^{14} \mathrm{C}$ simple is representative of rates of sediment accumulation in the western Valley (about 3.5 ft per $1000 \mathrm{gr}$ ). then the indicalted depth of Holocene alluvium (last $11000 \mathrm{yr}$ ) in the area would be about $38 \mathrm{ft}$. roughly $20 \%$ of the maximum amount estimated bi the CDWR.

Three other subdivisions have been made of near-surface materials within and adjacent to Livermore Valley. Huey (1948) separated the "Livermore Gravels" from the Quaternary terrace and alluvial deposits but did not further subdivide the Quaternary alluvium. Helley and others (1972) produced a map showing six subdivisions of the Quaternary alluvial sequence within Alameda County based upon soil types, strutigraphic position, and geomorphology. The portion of this map showing alluvial deposits near LLNL is shown as Fig. 13. Surficial deposits in the eastern Livermore Valley were largely mapped as Older Alluvial Fan Deposits (Qof) with some Younger Alluvial Fan Denosits (Qyf) near stream channels. Younger Alluvial Fan
Deposits predominate in the central and western portions of the Valley. The CDWR (1974) generally followed the alluvial classifications proposed by Helley and others.

Herd (1977) remapned the calstern two-thirds of the Livermore Valley and proposed a more detailed subdivision of the Older Alluvial Deposits than existed before. Herd recognized four subdivisions of the older alluvium based upon interpretalions of soil series, degree and depth of soil profile development, and correlations of terrace surfaces (sec Fig. 9). The four subdivisions were numbered Qoi, through Quid, respectively, based upon increasing relative ages. Herd did not provide detailed descriptions of these units or specific criteria for their recognition.

None of the previous investigaturs af Livermore Valley geology nere able to assign absolute ages 11 Qualternary alluvial units. Herd (1977) stated that all of the soils on older alluvial units have argillic (elaty-enriched) B horizons and are therefore of Pleistocene age. $\mathrm{He}$ cited Birkeland (1974) as having established that in California, some 40000 years of soil formation appear $t o$ be required to form a minimal $\mathbf{B}$ horizon. Herd regarded recent llood-plain alluvium and stream gravels as Holocene materials, a conclusion based on their deposition in the modern stram regimen.

A result of LINL studies has been the determination of several age dates for alluvial deposits present in exploratory trenches within LLNL and neighboring SWLL sits. Materials dated inctude a woud fragneml dated by the ${ }^{1+} \mathrm{C}$ method and several specimens of pedogenic carbonate ("ealiche") dated by the ${ }^{210} \mathrm{Th}_{i}{ }^{234} \mathrm{U}$ method developed by $\mathrm{Ku}$ and others (1979). Sample locations and dating methodology are discussed in Appendix ( of this volume and in Appendix $F$, found in Volume 11 of this rei art.

A comparison of the locations of dated materials with the late Quaternary stratigraphy proposed by Herd (1977) reveals the following:

- The ${ }^{44} \mathrm{C}$ date obtained from the wood fragment is $17400 \pm 250 \mathrm{yr}$ (Rubinson, 1980). The material containing the wood fragment was mapped by Herd as Qoa 2 . The sample site is in exploratory trench E-3, is locited beneath a terrace or alluvial lan surface, and is about $75 \mathrm{ft}$ northeast of Arroyo Seco Creek, within SNLL property (see Fig. 31).

- Two malure soil profiles were recognized in exploratory trenches excavated in the southeiste in 


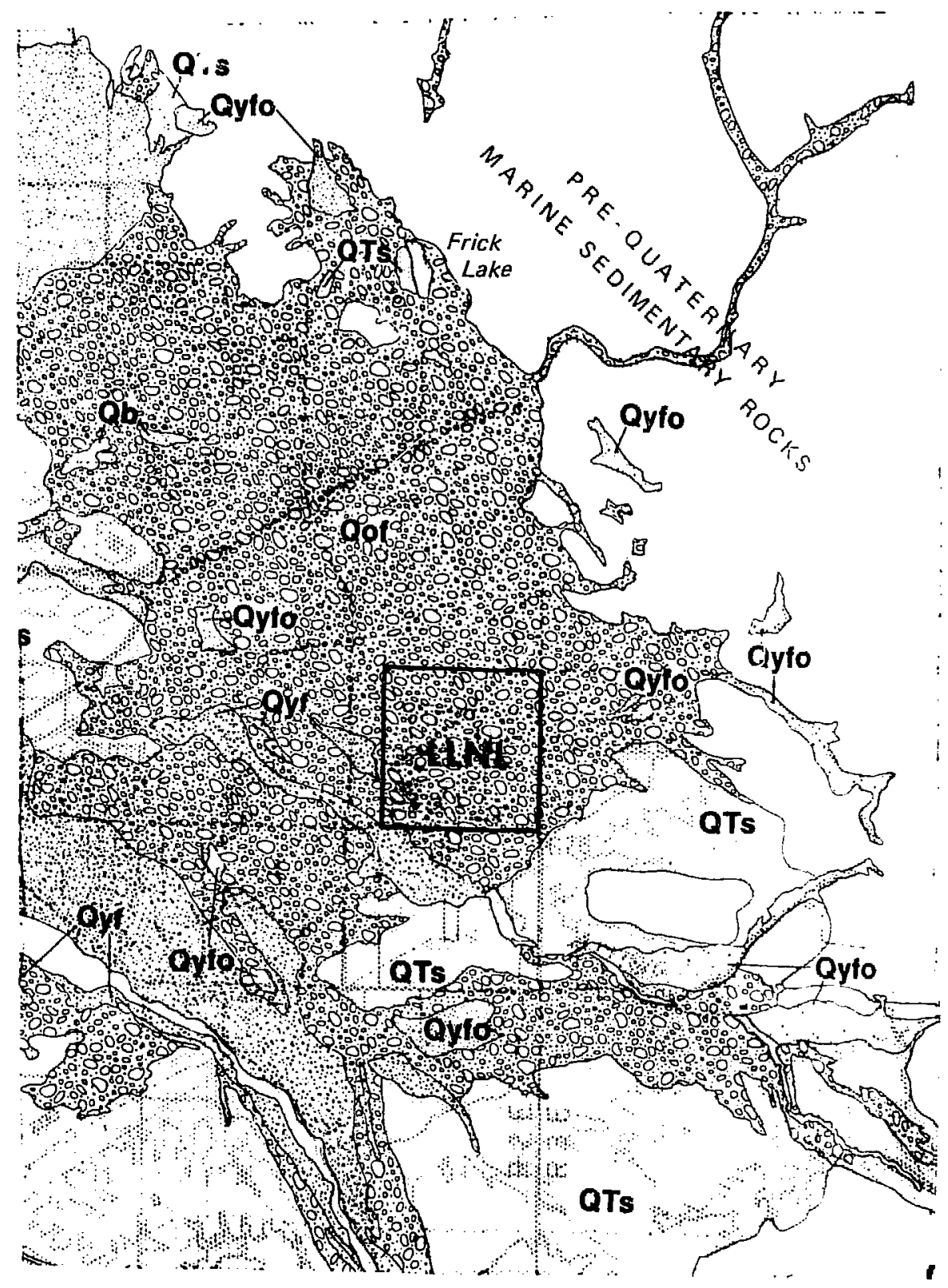




\section{DESCRIPTION OF UNITS}

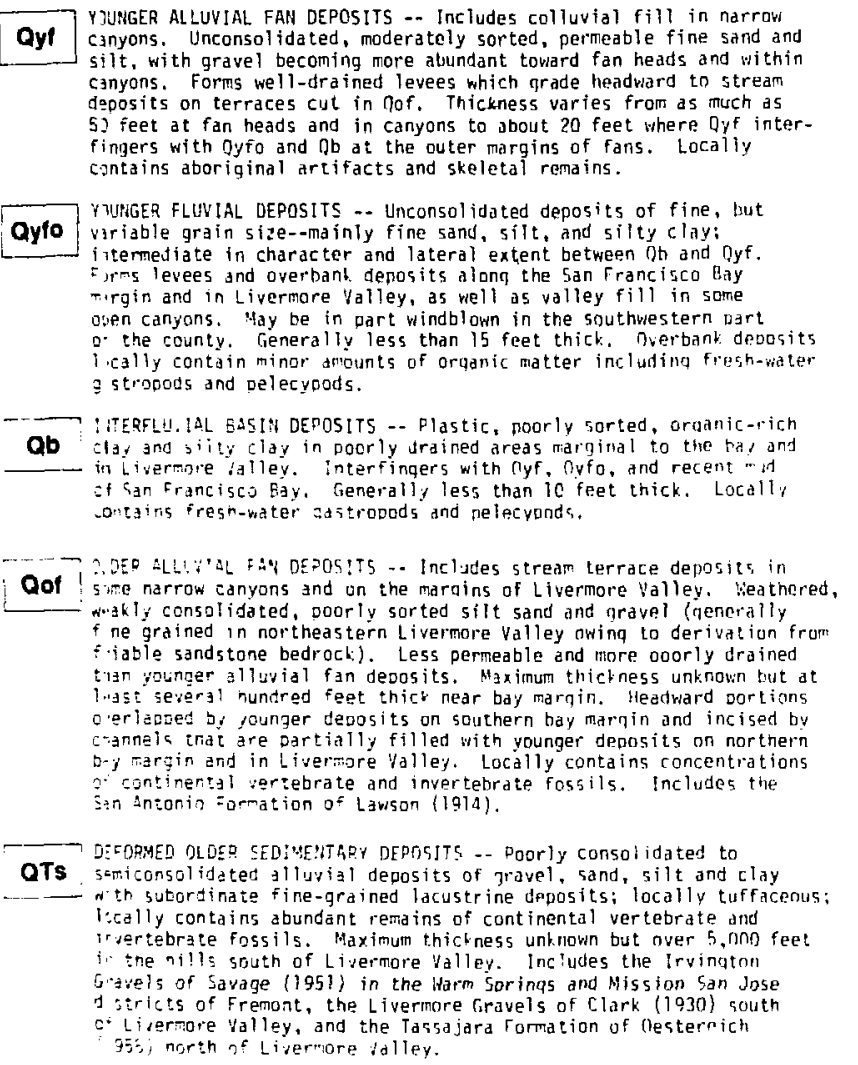



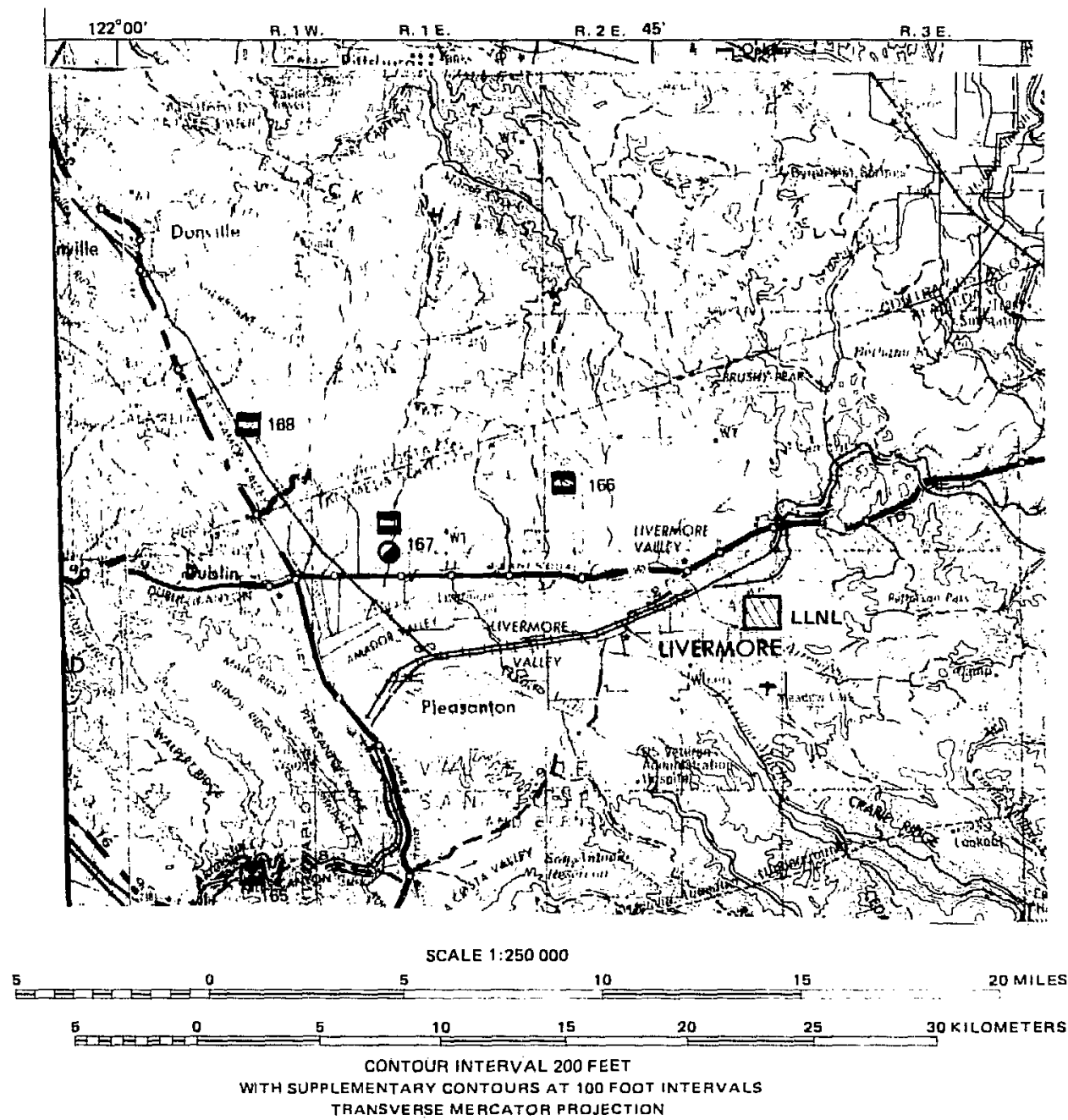

FIG. 14. Locations of reported gmound failures within Livermore Valley and nearby areas. The failures shown resulted from the great San Francisco earthquake, April 18, 1906 (location 165-167), and from an earthquake in 1861 (location 168), probably on the Calaveras Fault (from Youd and Hoose, 1978). Location 165 was a case of railroad tunnel distress and change in tunneling conditions. Locations 166 and 168 were cases of random ground fracturing not clearly associated with landsliding, lateral spreads, settlenent, or primary fault movements. Location 167 included a minor streambank slump. 
that an earthquake of magnituoie 8.3, the largest historically experienced on the San Andreas Fault, could generate a peak bedrock acceleration of $0.4 \mathrm{~g}$ at LLNL.

Hayward Fault. The Hayward Fault is located generally along the eastern margin of the San Francisco Bay plain and passes about $32 \mathrm{~km}(20 \mathrm{mi})$ southwest of LLNL at its closest approach (Fig. 4). The known length of the Hayward Fault zone has beun estimated as $72 \mathrm{~km}$ (45 $\mathrm{mi}$ ) by Wesson and others (1975).

Historic accounts of strong earthquakes along the Hayward Fault zone in 1836 and 1868 (ibid) provide evidence for its activity. Right lateral tectonic creep (ibid) and microseismic activity (Ellsworth and Marks, 1980) have been documented along the Hayward Fault zone in recent years.

The October 22, 1868 earthquake cuused surface faulting ulong the Hayward Fault zone from the Warm Springs district in Fremont, northward to San Leandro and possibly as far as Berkeley, (Fig. 4) (Wesson and others, 1975). Ground failures as far away as San Francisco, were caused by the October, 1868 earthquake. However, none were reported from the Livermore Valley, which was then sparsely settled (Youd and Hoose, 1978).

Wesson and others (1975) indicate a maximum probable earthquake of magnitude 7.0 for the Hayward Fault zone, based on empirical lenglhmagnitude relationships. The earthquake on October 22,1868 is believed to have had a magnitude of $7 \pm 0.5$ (ibid) and was therefore probably a near-maximum event for the Hayward Fuult zone. Wight (1974) estimated that an earthquake on the Halyward Fault of magnitude 7.5 at a distance of $42 \mathrm{~km}(26 \mathrm{mi})$ could generate a peak bedrock acceleration of $0.35 \mathrm{~g}$ at LLNL.

Calaveras Foult. The Calaveras Faull zone branches from the San Andreas system near Hollister, (slightly south of the limits of Fig. 4) and trends northwest to the San Ramon Valley, a distance of about $115 \mathrm{~km}(72 \mathrm{mi}$ ) (Wesson and others, 1975). The Calaveras Fault zone forms the western margin of Livermore Valley and is located about $17 \mathrm{~km}$ (11 mi) west of LLNL at its closest approach (Fig. 4).

The Calaveras Fault zone has been historically active and a major earthquake in 1861 (estimated magnitude 6+) within the Livermore or San Ramon Valley has been attributed to the Calaveras Fault (Radbruch, 1968) (Fig. 15). Evidence for Holocene and probably historic surface faulting has been seen along the Calaveras Fault in the Dublin area (Burkland and Associates, 1975c; Earth Sciences Associates, 1971) and in the vicinity of the Castlewood Country Club, southwest of Pleasanton, (Judd Hull and Associates, 1975). Ground failure appears to have occurred in the San Ramon area during the 1861 earthquake (location 168 on Fig. 14) (Youd and Hoose, 1978).

The Calaveras Fault constitutes a groundwater barrier in the Dublin area (Burkland and Asso:iates, 1975c), with water levels higher on the west side of the fault zone. Displaced stream channels and topography in the Dublin area indicate dominantly right lateral strike-slip movement along the Calaveras Fault zone but with some uplift west of the fault, Right lateral tectonic creep has been measured along the segment of the Calaveras Fault zone south of Sunol (Wesson and others, 1975) and considerable microseismicity is associated with this portion of the Calaveras Fault zone (Ellsworth and Marks, 1980).

A moderate earthquake $(M=5.7)$ occurred on the Culaveras Fault near Coyote Reservoir north of Gilroy, on August 6, 1979 (Kerr, 1979). The earthquake struck in a lightly populated area and caused relatively little damage. Minor surface faulting occurred in the vicinity of the epicenter (ibid).

Wesson and others (1975) indicate a muximum probable earthquake of magnitude 7.3 for the Calaveras Fault zone, based on empirical lengthmagnitude relationships. Wight (1974) estimated that an earthquake on the Calaveras Fault of magnitude 7.5 at a distance of $17 \mathrm{~km}$ (11 mi) could generate a peak bedrock acceleration of $0.5 \mathrm{~g}$ at LLNL.

Faults in Livermore Valley and Adjacent Areas. In addition to the Calaveras Fault, the CDWR (1966, 1974) mapped six other major faules and six minor faults within the Livermore Valley. Faults mapped in the Valley by the CDWR in 1966 and 1974 are shown on Figs. 6, 15 and 16. Fault locations were based largely on apparent groundwater now barriers and variations in water quality, but CDWR studies also included air photo interpretation and limited geophysical investigations.

The six other major faults identified by the CDWR (1974) were the Carnegie, Corral Hollow, Tesla, Mocho, Livermore and Pleasanton Fuults. The six minor faults included the Verona, Purks and four local, unnamed faults. The CDWR (1974) also 


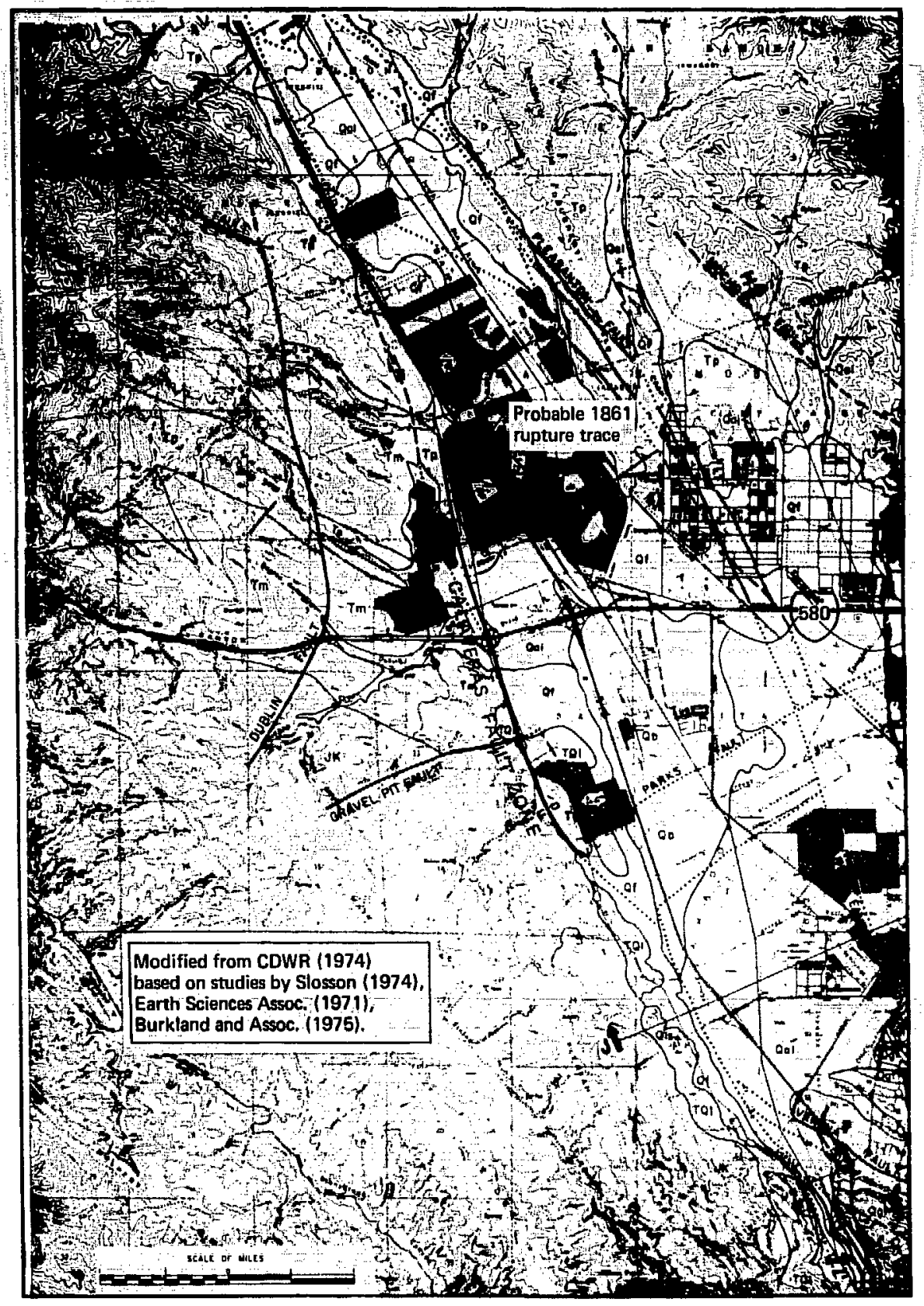

FIG. 15. Faults in western Livermore Valley (CDWR, 1974). 


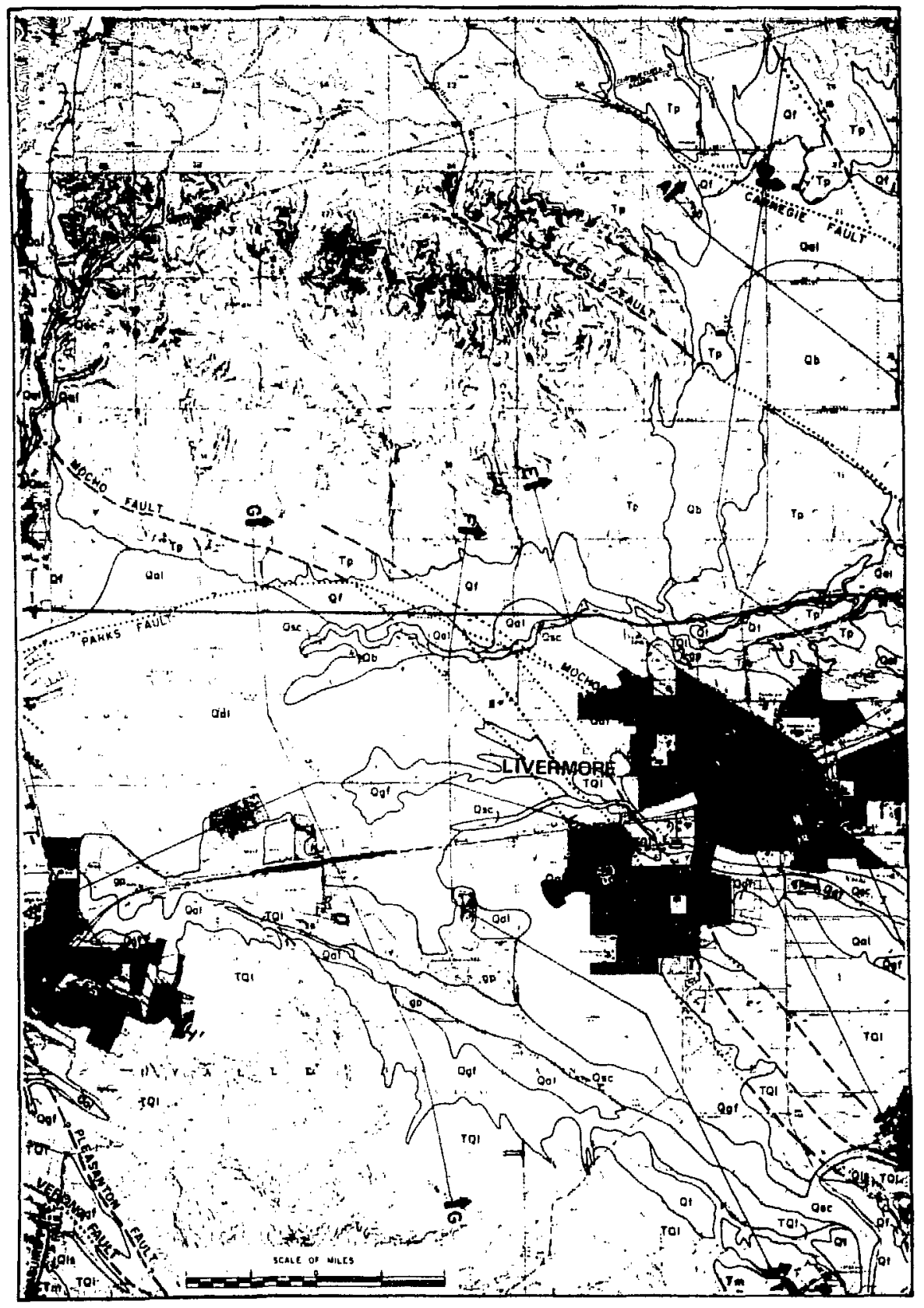

FIG. 16. Faults in central Livermore Valley (CDWR, 1974). 
mapped the Williams and Valle Faults in the foothills south of Livermore Valley (see Fig. 34). In 1979, the CDWR provided additional data on the Livermore and Carnegie Fault zones.

Huey (1948) mapped the Greenville Fault as bounding the easturn margin of the Livermore Valley. Huey mapped four additional fuults in the hills southeast of Livermore Valley. From northeast to southwest these are the Patterson Pass Fault, the Carnegie Fault, the Corral Hollow Fault, and the Tesla Fault, respectively (see Fig. 5).

Hucy showed the Greenville Fault erossing Quaternary alluvium in the vicinity of Frick Lake in the northeast corner of Livermore Valley. Huey did not show any of the other faults displacing Quaternary alluvial deposits although he showed these faults as locally separating the Livermore Formation from older units.

Blume (1971, 1972) mapped the Doutherty and Ramp Thrust Faults in eustern Livernore Valley (Fig. 7), However, subsequent investigators have not recognized these ats Valley structures.

Herd (1977) mapped the Greenville and Las Positas Faults as major Valley structures. He also presented evidence for relocating the Verona Fault and suggested that it is mort significant than previously believed. The CDWR (1979) noted the probable presence of the Las Positas Fault but regarded it as a local structure limited to the area from Arroyo Del Valle northeast to Arroyo Seco (Fig. 11).

Descriptions of all reported faults are given in the following subsections. Reported faults are discussed in alphabetical order.

Carnegie Fault. Huey (1948) (sec Fig. 5) mapped the Carnegie Fault in the hills east of LLNL and found evidence near its northwestern linit for a faulted contact between the Livermore Formation and the Cretaceous Panoche Formation (Great Valley Sequence). He did not recognize effects of the fault on Quaternary alluvial deposits along the projected location of the fault and therefore mapped it as buried and dying out beneath alluvial cover.

\footnotetext{
-The CDWR (1966) inapped the Greenville Fault bounding the eastern margin of the Livermore Valley but did not discuss it further, possibly because it did not materially influence the Valley ground water system.
}

The CDWR (1974) (see Fig. 6) did not specifically identify a groundwater barrier along the Carnegie Fault as projected across the nọrtheastern portion of the Livermore Valley. They did separate the Altamont subbasin from the Spring subbasin to the southwest along the projected fault trace (CDWR, 1974).

The Carnegie Fault has been locited in the Livermore Oil Field approximately $1 \mathrm{~km}(0.6 \mathrm{mi})$ northeast of LLNL (Blume 1972). Fault movement is upward on the north side. South of the fault, steeply dipping Tertiary sediments form the north Nank of the Livermore yncline (ibid).

During an investigation of private properties in the northern Livermore Valley, Cooper-Clark and Assuciates (1973) identified geophysical anomalies in the vicinity of the Carnegie Fault as projected by the CDWR. They also reported slickensides and overturned beds in the Tertiary Cierbo Formation along the trate of the Carnegie Fault north of Raymond Road. Evidence was cited for possible tectenit creep where the fault is projected to eross the South Baty Aqueduct. Based on their observations, thcy concluded that the Carnegie Fault was an active structure, although they gave no specific criteria for their judgement.

In their 1979 study (see Fig. 11), the CDWR showed the Carnegie Fault extending along the northeastern margin of the Livermore Valley. They reported that the Carnegie Fault is a high angle reverse fault. The Carnegie Fault is not well exposed in the area but the CDWR stated that it could be traced across the Livermore Oil Field by interpretation of well logs. Geomorphic features along the trace of the Carnegie Fault and its close relationship with the active Greenville Fault suggested to the CDWR that the Carnegic Fault is active.

The CDWR (1979) mapped a fault crossing the South Bay Aqueduct at Station $544+75$ (see Fig. 11). The fault was observed in Pliu-Pleistocene Livermore Gravels but was not seen in younger alluvium to the north. The fault was regarded as a possible branch of the Carnegie Fault zone.

Herd (1977) (Fig. 9) mapped the Carnegie Fault as being truncated by the Grenville Fault and considered the outcrop reported by CooperClark and Associates (1973) to be an exposure of the Greenville Fault zone. Herd also included the main trace of the Carnegie Fault zone as shown by the CDWR (1979) as part of the Greenville Fault zone. 
LLNL has investigated the Carnegie Fault in the hills southeast of the Laboratory. The Carnegie Fauls is poorly exposed in the north end of Sec. 22 , T3S. R3E, where it forms the contact between the Neroly and Cierbo Formations. Differences in location of the falult northwest of See. 22 that are shown by other investigators result from the heavy soil tover and uncertainty of the Cierbo-Neroly contact. Roads recently constructed in the area provide additional information that is presently being cvaluated.

During LLNL field reconnaissance, it was found that northwest of Sec, 22 the Carnegie Fault could not be traced with any ac aracy, although several springs and topographic depressions may mark its trace. No disruption of the soil cover was seen in stream or road euts along its strike. People living along the trace felt only a minimum of motion during a June 1977 sejsmic event (see below for further discussion of this earthquake). Further to the sombeast. Huey (1948) mapped the Carnegie Fault us merging with the Tesla Fault (Fig. 5).

Corral Hollow Fault. Huey (1948) (Fig. 5) mapped the Corral Hollow Fault as locally displacing the Livermore Formation but showed the fault as dying out before reaching the Valley. During its initial studies, the CDWR $(1966,1974)$ projected the Corral Hollow Fault northwest across the Livermore Valley as a subsurface feature (see Fig. 6) but in 1979, the CDWR mapped the Corral Hollow Fault essentially as it had been mapped by Hucy (see Fig. 11).

The CDWR (1974) did not recognize the Corral Hollow Fault as a factor influencing Valley geohydrology. Evidently the CDWR could find no influence on groundwater movenent or quality related to the Corral Hollow Fauit. Blume (1972) did not observe any evidence for the Corral Hollow Fault in geophysical profiles performed within and immediately southeast of LLNL.

During LLNL field reconnaissance, surface evidence for the Corral Hollow Fault was sought starting in Sec. 35, T3S, R4E, where it branches from the Tesla Fault as mapped by Hucy (1948). Huey has shown the fault crossing Corral Hollow road and truncating the upper part of the Tesla Formation in this arca. The fault is not easily traced to the northwest and no evidence for it could be observed west of Sec. 21, T3S, R3E. At none of the locations where the Corral Hollow Fault was mapped by Huey could any geomorphic features be ob- served that were suggestive of geclogically youthful movements.

As part of a detailed exploratory program. LLNL geoscience personnel directed excavation of trenches in two areas shown on Fig. 17. As shown on Fig. 18, exploratory trench E-5 within LLNL was excavated across the trace of the Corral Hollow Fault as projected (see Fig. 6) by previous in. vestigators (Blume 1971; CDWR, 1966, 1974). The trench was extended to cross vague linear tonal contrasts noted on aerial photographs. No evidence for faulting was observed in alluvial deposits exposed in trench E-5. A specimen of pedogenic carbonate was obtained from fractures (probably fossil desiccation cracks) within a silty clay bed present at a depth of $11 \mathrm{ft}$ in Trench E-5. The age of the pedogenic carbonate determined by the ${ }^{230} \mathrm{Th} /{ }^{234} \mathrm{U}$ method is approximately $23000 \mathrm{yr}$, indicating that the trench extended deeply enough to expose late Pleistocene materials. A detailed geologic log and summary description of trench E-5 are included in Appendix F (in Volume II) as Fig. F-6.

Doutherty Fault. Blume (1972) (see Fig. 7) identified and mapped the Doutherty Fault as crossing the northeastern portion of LLNL, based on their inter pretation of geophysical data. Gravity data indicn:ed that the northeast block appears displaced up and seismic refraction data suggested a groundwater barrier along the postulated fault (ibid).

The postulated Doutherty Fault has no physiogruphic expression either in the Valley alluvium or in the hills to the southeast. However, URS/Blume (1978) reported a night infrared (IR) photo lineament near the suspected fault trace (see Fig. 18).

During the summer of 1979, an approximately 20-10-24-ft deep basement excavation was made for the Noval addition to the Shiva laser facility at LLNL (Bldg. 391). The basement excavation is located across a trace of the Doutherty Fault as mapped by Blune (1972). Two 8-to-10-ft deep storm drain trenches excavated as part of the Bldg. 391 project also cross strands of the Doutherty Fault as mapped by Blume (1972) and the night IR lineanient reported by URS/Blume (1978).

Ceologists from LLNL and elsewhere inspected these excavations for evidence of faulting and found none. In order to document the geologic observations, detailed logs were prepared for segments of the two storm drain trenches and for the 


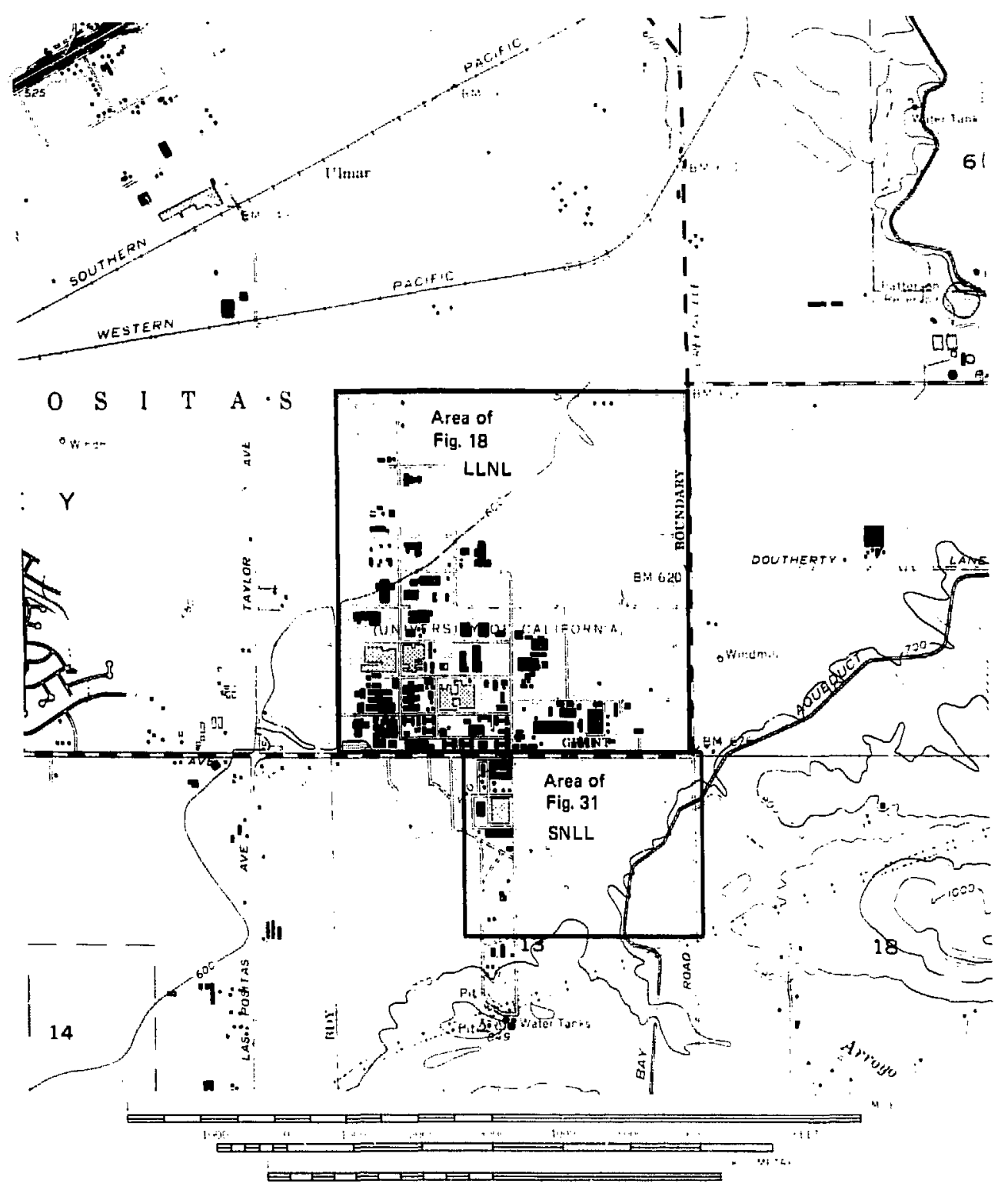

CONIOUR INITEVAL OT FEE

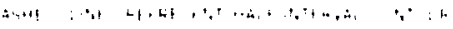

NATIONAL GEODETIC VERTICAL DATUM OF 1929

FIG. 17. Key map locating areas of exploration that are shown in more detail in Figs. 18 and $\mathbf{3 1 .}$ 


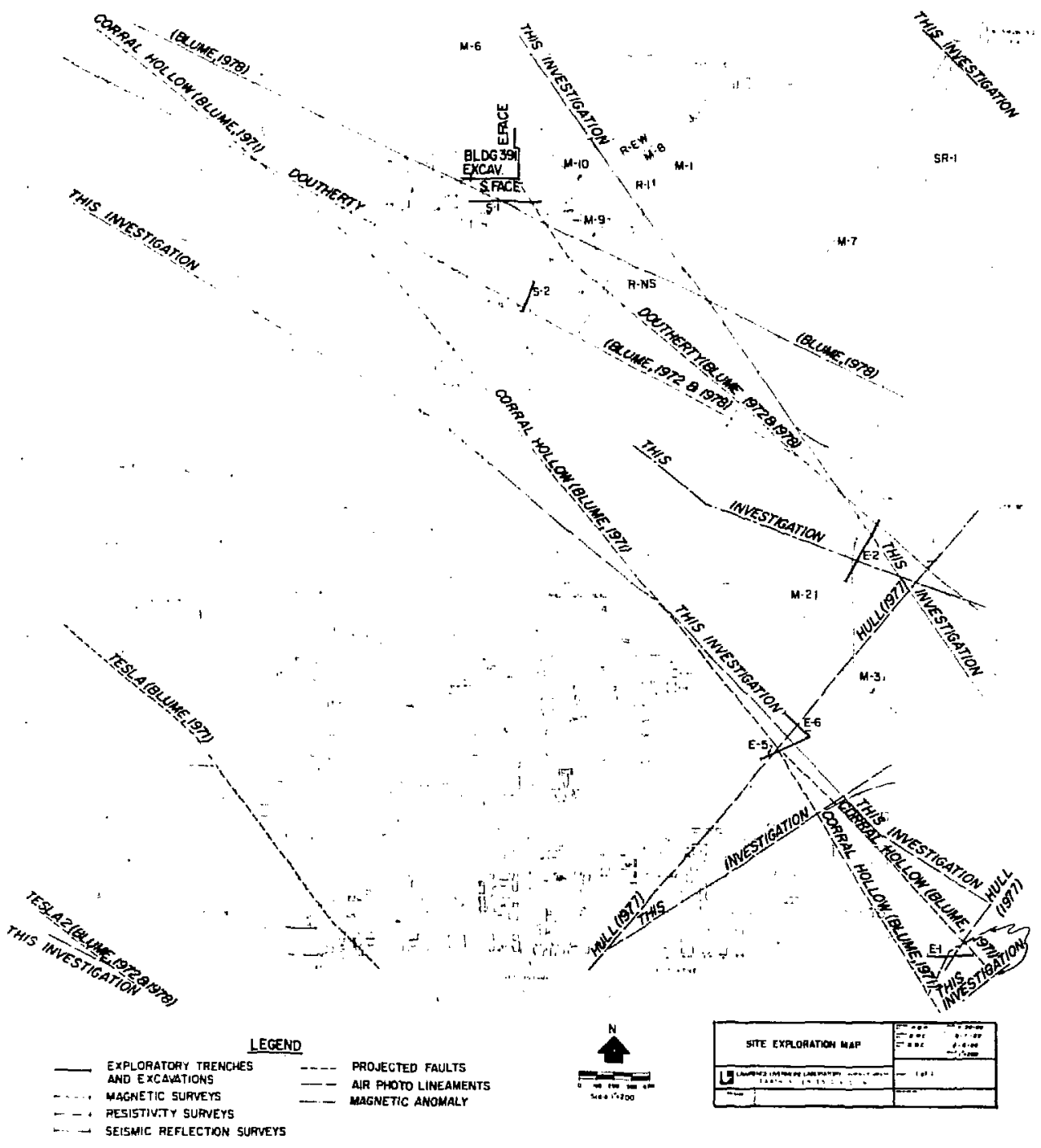

F16. 18. LLNL site map showing locations of postulated faults, airphoto lineaments, excavations studied, and genphysical surveys made. 
south and east faces of the Bldg. 391 excavation. Locations of logged exposures are shown in Fig. 18 and detailed logs and summary descriptions of the exposures are included in Appendix $\mathbf{F}$ (Volume II) as Figs. F-8 through F-11. The excavations exposed complexly interbedded and lensed sandy silts, sands, and fine to coarse gravel beds. Slight clay entichment and local presence of caliche were noted in the alluvial deposits immediately below original ground surface, indicating moderate soil profile development characteristic of Pleistocene ruther than Holocene alluvial deposits (Herd, 1977). Gravels backfilling an ancient stream channel were found in the general vicinity of the night IR lineament. Difference in soil moisture between the gravel deposits and adjacent finer sediments could create the observed lineament.

LLNL geoscience personnel directed excavation of exploratory trench E-2 in the eastern portion of L.LNL, across the mapped fault trace. The trench site has been mapped by Herd us unit Qoa, The trench exposed older alluvisl deposits with a welldeveloped soil profile. Several ancient stream channel deposits were found in the trench but no features suggestive of faulting were observed. The location of Trench E-2 is shown on Fig. 18. A detailed log and summary description of the trench are included in Appendix F (Volume II) as Fig. F-2. A sample of pedogenic carbonate obtained at a depth of $5.5 \mathrm{ft}$ in trench E-2 was found to be unsuitable for dating by the ${ }^{230} \mathrm{Th} /{ }^{234} \mathrm{U}$ method (see Appendix C). A poor wood specimen was also obtained from trench E-2 but was judged unsui'.ble for dating (Robinson, 1980).

Greenville Fault. The Greenville or GreenvilleRiggs Canyon Fauli zone is a major structural feature of the Livermore Valley-Mt. Diablo area.

Herd (1977) (see Fig. 9) mapped the Greenville Fault zone along the eastern boundary of the Livermore Valley and reported geomorphic evidence for recent activity and displacement of late Pleistocene unit $\left(\mathrm{Qoa}_{2}\right)$ along it. He concluded that the Greenville Fault continues southeast of Livermore Valley, buried beneath the Livermore Formation and younger alluvium, and that it truncates the Carnegie and Tesla Faults in that area.

Unquestionable evidence for activity along the Greenville Fault zone was provided at 11:00 a.m. PST on Thursday, January 24, 1980 when an earth- quake of $\mathrm{M}=5.9$ (USGS) occurred approximately $17 \mathrm{~km}(1 \mathrm{l} \mathrm{mi})$ north of Livermore, on the Marsh Creek Fault (see Fig 19) (Cockerham and others, [980). The earthquake caused discontinuous surface faulting along and near several strands of the Greenville Fault zone as mapped by Herd (1977) and by Brabb and others (1971). Locaticns of surfuce fuulting as compiled by the U.S. Geological Survey (Bonilla and others, 1980) are shown in Fig. 20. Descriptions of features at various locations shown on Fig. 20 are presented in Appendix E (dutal laken from Bonille and others, (980),

A single foreshock preceded the earthquake and over 600 aftershocks followed during the next 33 days (Cockerham and others, 1980). The largest aftershock occurred at 6:33 p.m. PST on Saturday, January 26,1980 . It had a magnitude of $M=5.3$ ani $i$ occurred about $14 \mathrm{~km}(9 \mathrm{mi})$ southeast of the main shock (ibid) (see Fig, 19).

Field reconnaissance studies following the enrthquake were made by geologists from LLNL, the USGS, various State and Local Governments, and private consulting firms. Most of the surface fault fealures shown on Fig. 20 were visible on Friday, January 25, 1980 following the main earthquake. However, additional surface faulting and fracturing occurred during the Saturday, January 26. 1980 event; numerous new cracks and enlargement of older ones were observed on Sunday, January 27, 1980. The new cracks were mostly concentrated near the southeasterly end of the zone of surface faulting, mainly in the vicinity of locations $18,19,20$, and 22 shown in Fig. 20. Representative photographs of surface faults found by LLNL geologists after the earthquakes are shown in Figs. 21 through 28.

The area of discontinuous surface faulting along the Greenville Fault zone extends from the vicinity of the intersection of Greenville Road and Interstate Highivay 580 northwest to Sec. 15, T2S, $R 2 E$, a distance of approximately $6.4 \mathrm{~km}(4 \mathrm{mi})$. The area affected by surface faulting ends about $\mathbf{2 . 6}$ $\mathrm{km}(1.6 \mathrm{mi})$ north of LLNL.

The areal affected by discontinuous surface faulting is southeast of the main shock epicenter and separated from it by about $9 \mathrm{~km}(5.6 \mathrm{mi})$ (Cockerham and others, 1980). The extent of the separation and characteristics of the shallow aftershock $p^{*}$ tern led Cockerham and others to 


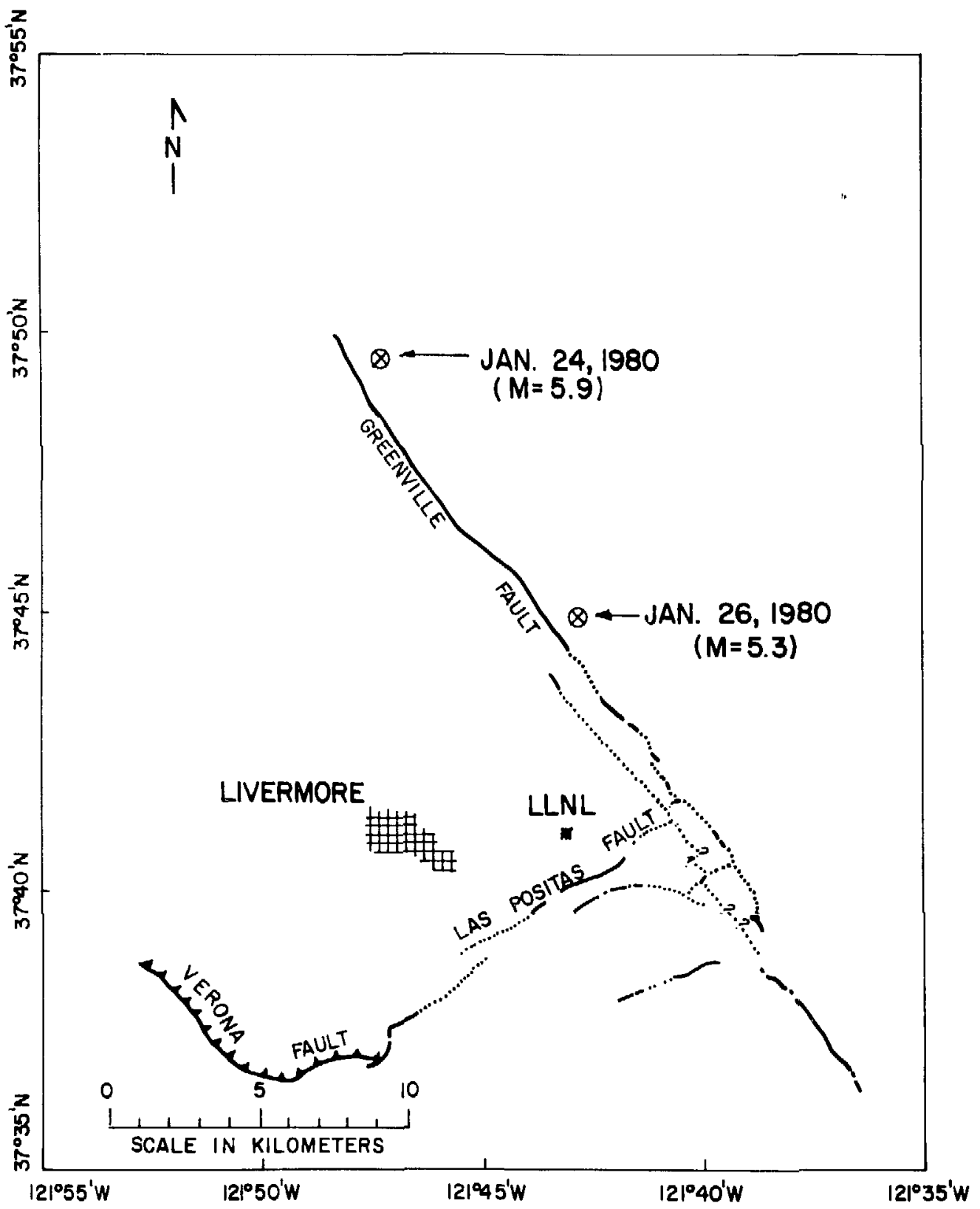

FIG. 19. Locations of main shock and principal aftershock of Livermore Valley earthquake series, January 24, 1980 and following (adapted from Cockerham and others, 1980). 


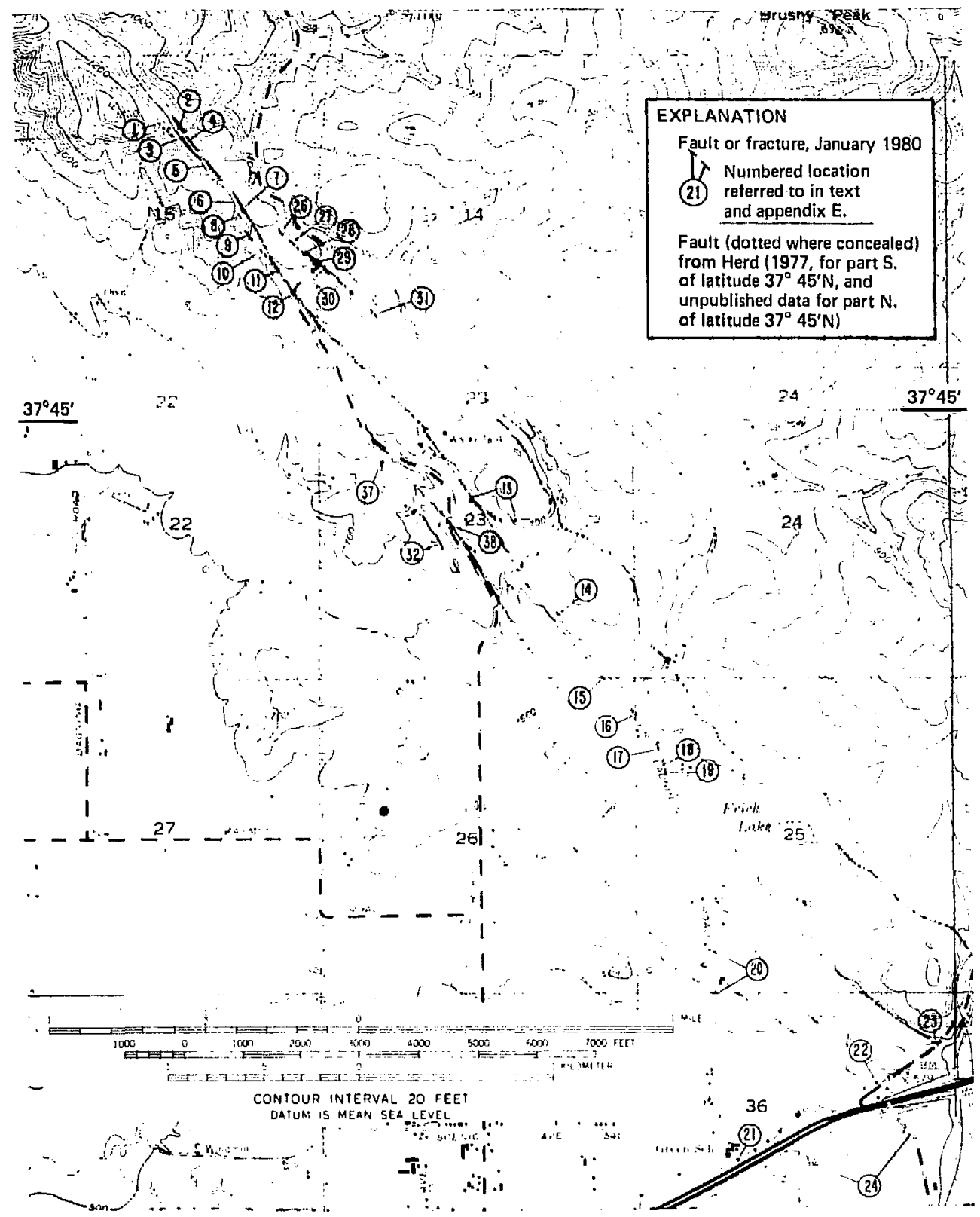

FIG. 20. Locations of surface faulting, Livermore Valley earthquake series beginning January 24, 1980 (from Bonilla and others, 1980). 


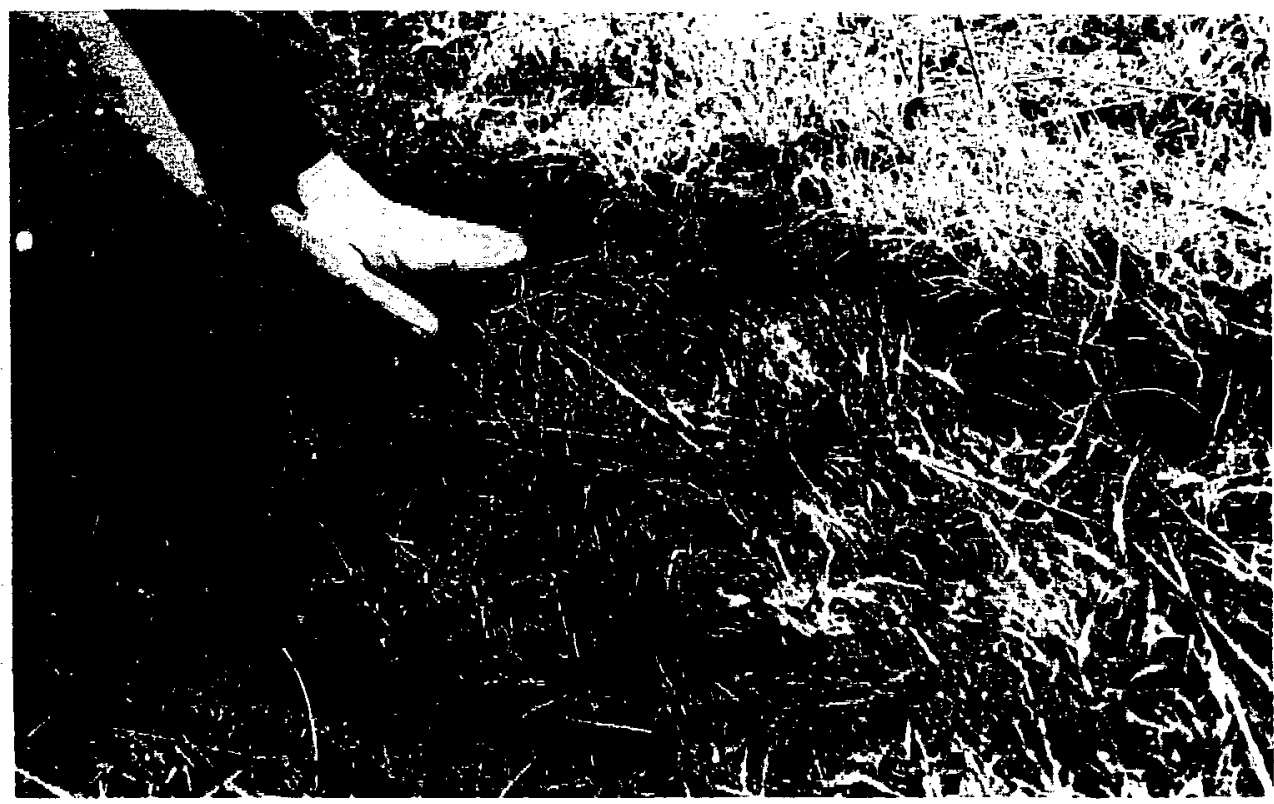

FIG. 21. Surface faulting during January 24, 1980 earthquake on Greenville Fault zone, shown as location 27 on Fig. 20. The amount of offset is about $2 \mathrm{~cm}$ horizontal and vertical. (Photo by A. Ramirez, LLNL).

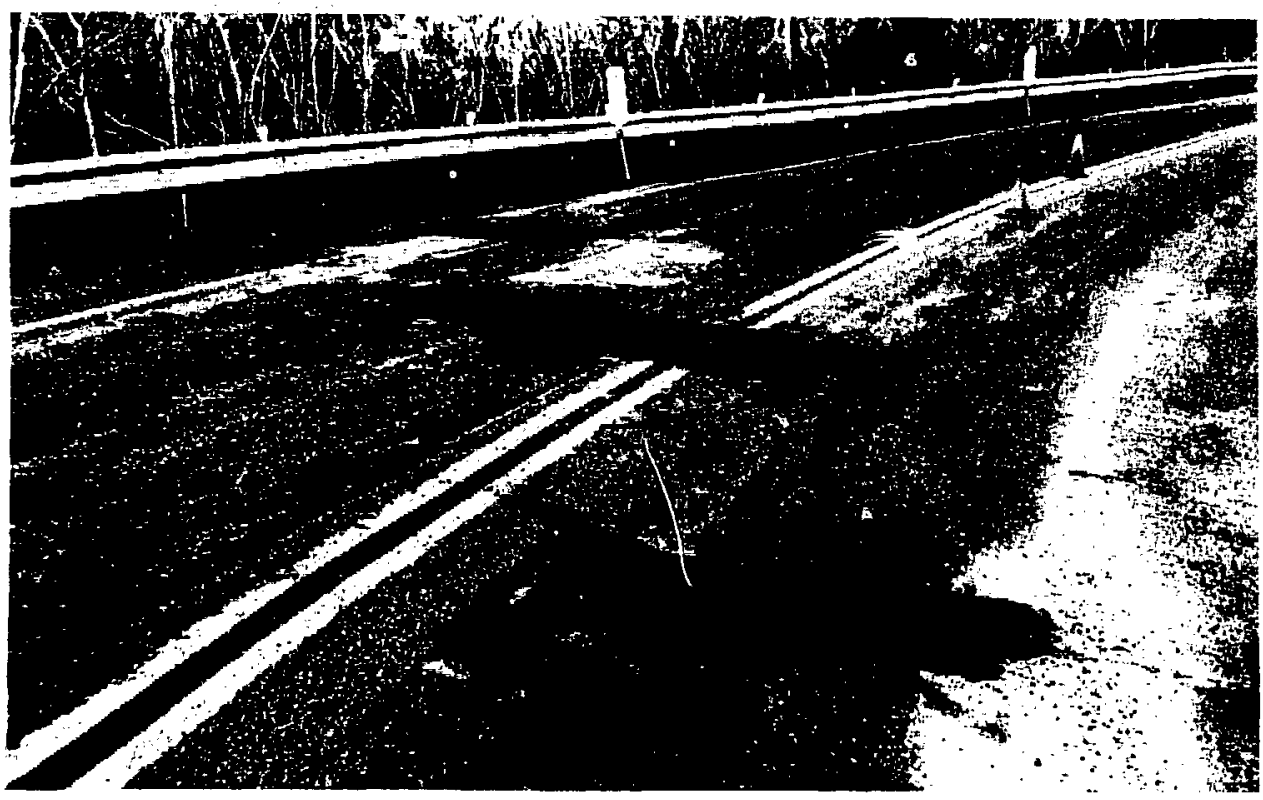

FIC. 22. Surface faulting caused by January 24, 1980 earthquake. Fault crosses N. Vasco Road, shown as locatinn 12 in Fig. 17. Alameda County road crew repaired the road on January 24, 1980 because pavement buckling was sufficient to interfere with traffic safety.(Photo by A. Ramirez, LLNL). 


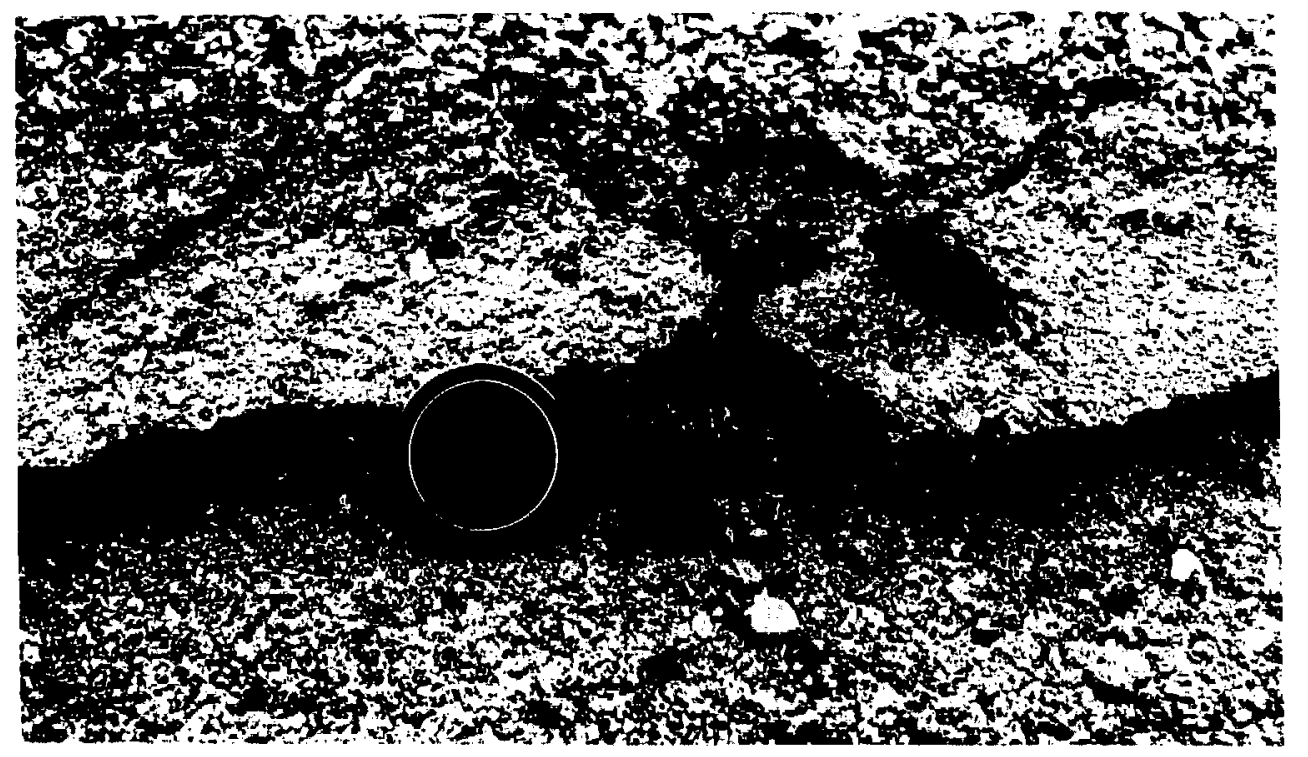

FIG. 23. Fractures in pavement at location 12 in Fig. 20, prior to repair. Lens cap is approximately $50 \mathrm{~mm}$ in diameter. (Photo by H. Ganow, LLNL).

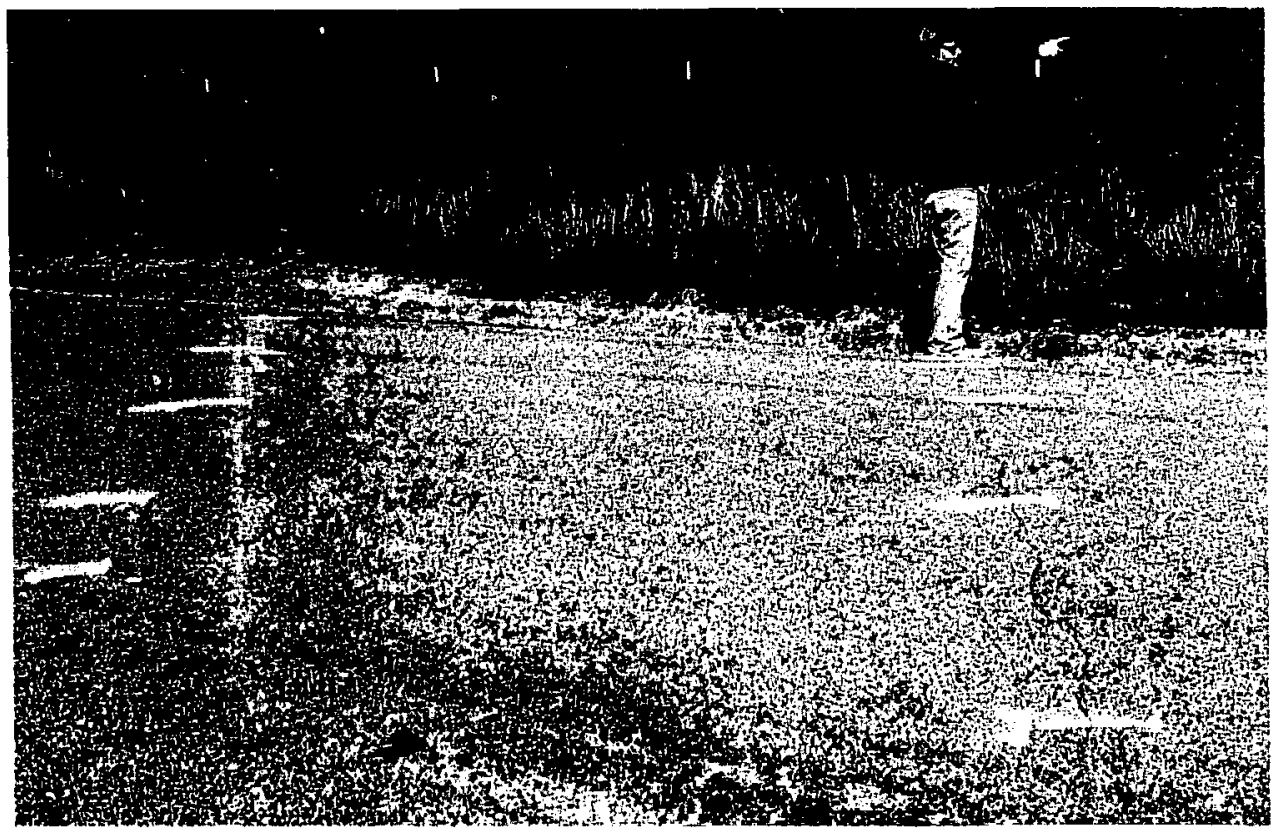

FIG. 24. Zone of numerous fractures in pavement of Laughlin Road at location 17 in Fig. 20. Field reconnaissances on January 25 and January 27,1980 demonstrated a considerable increase in frequency of fracturing in this area following the main aftershock on January 26,1980 . Subject shown in photo is pointing southeast along the strike of the Greenville Fault zone. (Photo by A. Ramirez, LLNL). 


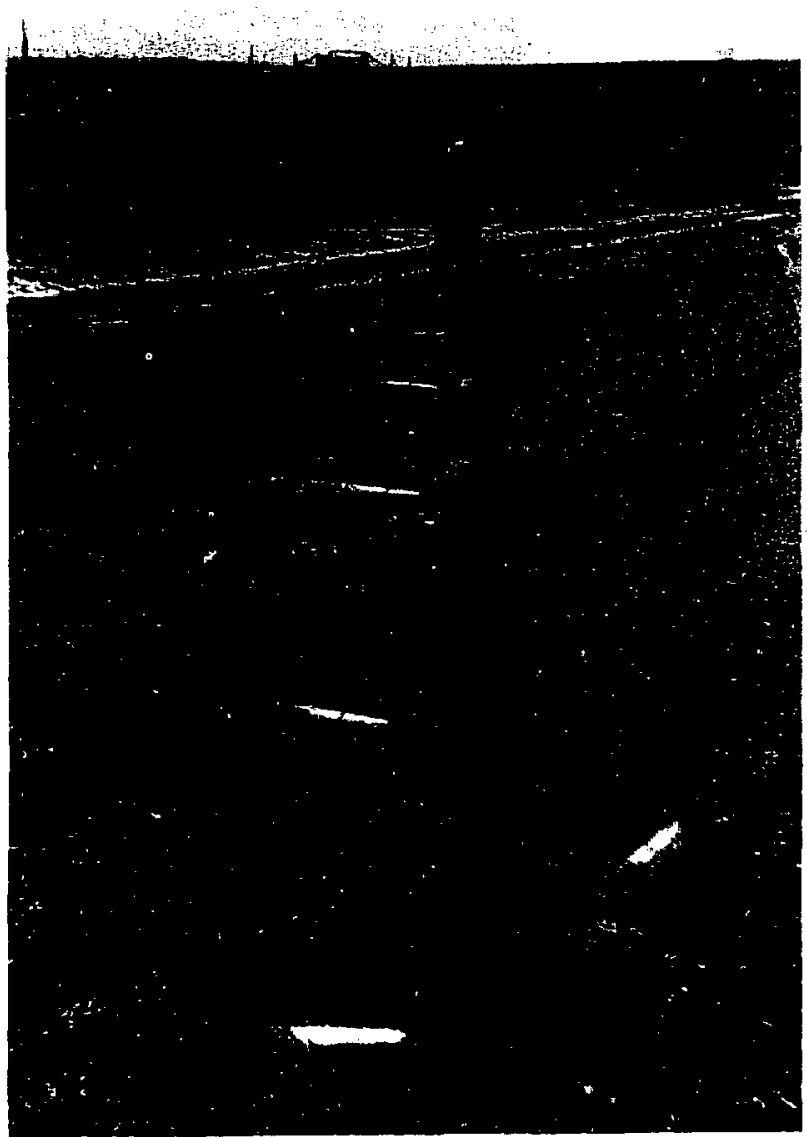

FIG. 25. Southeast striking fracture crossing Laughlin Road near the south limit of location 20 on Fig. 20. The fracture correlates closely with the strand of the Greenville Fault zone mapped by Herd (1977). (Photo by A. Ramirez, LLNL).

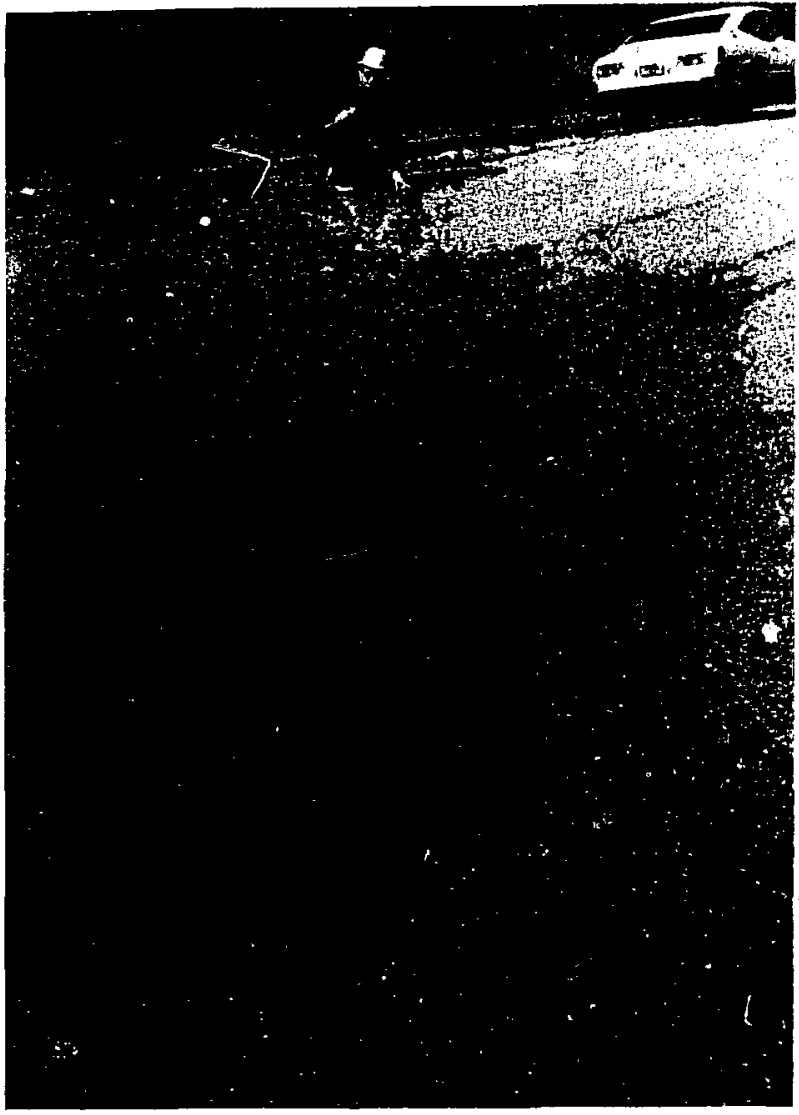

FIG. 26. Fracture crossing Laughlin Road at location 18 in Fig. 20. Trend of fractures in this area and at location 19 (behind photographer) is about $N 10^{\circ} \mathrm{W}$ in contrast to $\mathrm{N} 40^{\circ} \mathrm{W}$ trend of the main zone. This change in trend suggests the presence of a subsidiary cross fault along which surface rupture transferred from the main trace to a more southwesterly trace (locations 20 and 22 in Fig. 20). (Photo ty A. Ramirez, LLNL). 


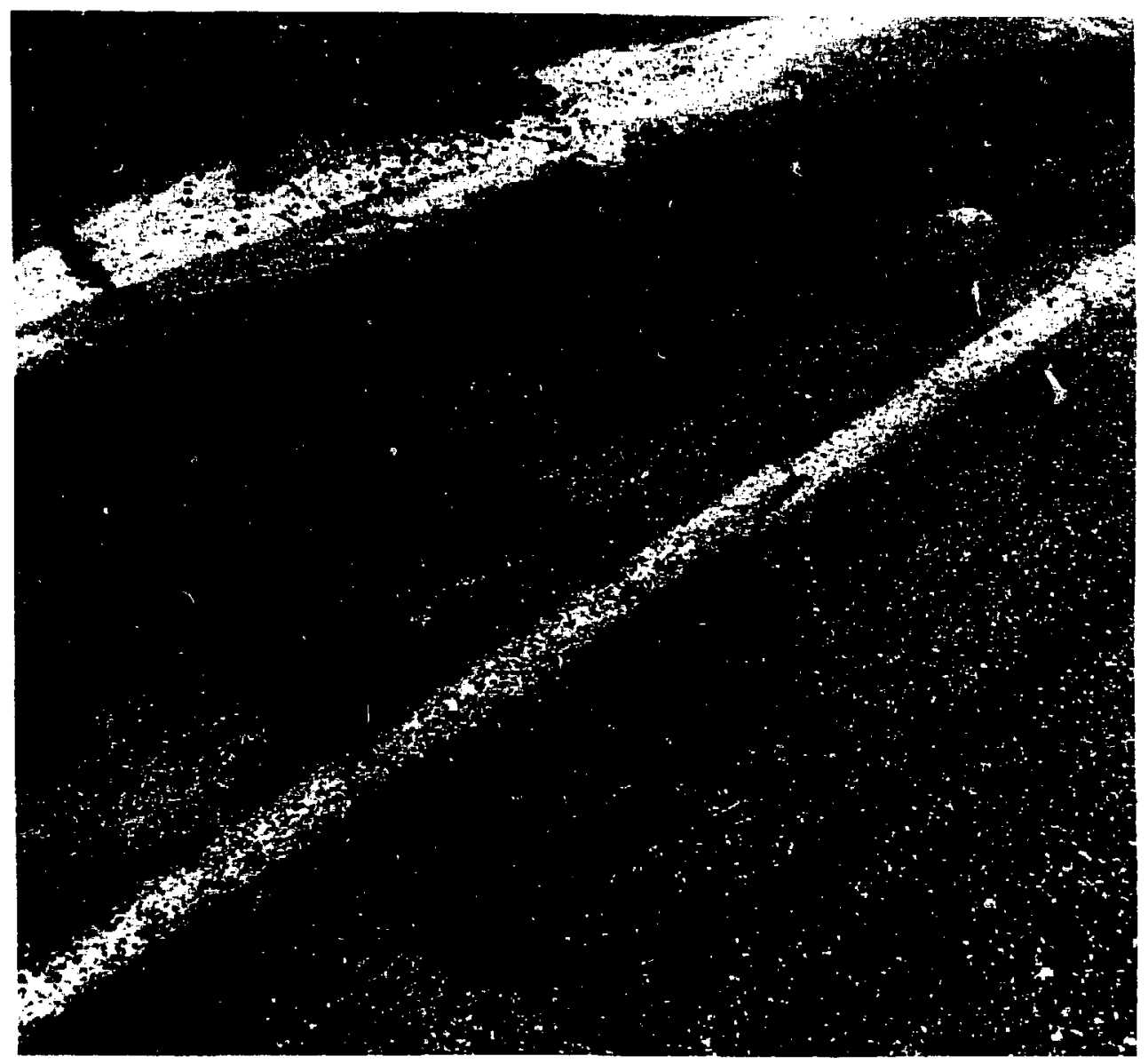

FIG. 27. En echelon left-stepping shears indicating right-lateral strike-slip movement linking repaired pavement buckles in N. Vasco Road, shown as location 12 in Fig. 20. (Photo by A. Ramirez, LLNL). 


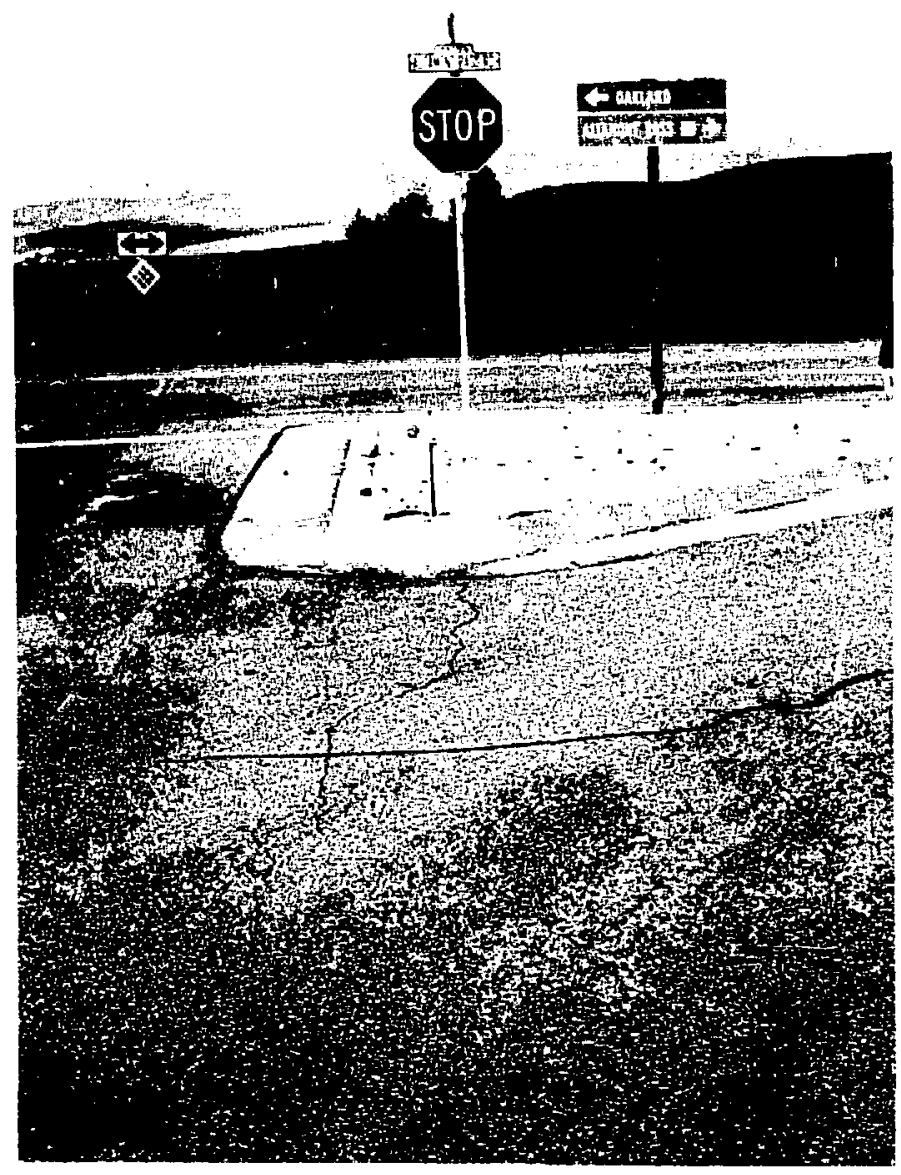

FIG. 28. Shears in pavement on the east side of Greenville Road at the intersection with Altamont Road, shown as location 22 in Fig. 20. Fractures at this location are right stepping and suggest apparent left lateral movement near the south end of the surface rupture zone. (Photo by A. Ramirez, LLNL). 
speculate that the zone of surface displacement may not be continuously connected to the zone of rupture at depth but may be sympathetic in origin.

Preliminary strong motion data for the January 24 and January 26, 1980 earthquakes have been compiled and are presented in Table 1 . No strong motion instruments were in operation at LLNL at the time of the earthquakes, but Tokarz and Shaw (1980) have estimated a peak ground motion of $0.2-0.3$ g for the Laboratory Site.

Very strong ground merions were experienced hy many residents of southern Contri Costa County during the January 24 and January 26, 1980 earthquakes. In a few instinces, apparent ground motions eaused by the January 26, 1980 carthquake exceded those caused by the January 24 event. LLNL tivil enginaer Roger Lake courdinated to forts by members of the Tassajara Volunleer Fire Department in compiling relative intensity data for the area, batsed on the Modified Mercalli Stille (Richter. 1958). Results of their work are shown in Fig. 29.

On June 21, 1977 a moderale earthquake $(M=4.7)$ wats felt in Livermore Valley and nearby areas. Based upon refined crustal model data developed following the January 1980 earthyuakes. Elsworth and Marks (1980) relocated the epicenter for the 1977 evert at $37^{\circ} 38^{\prime} \mathrm{N}$ lat. $121^{\circ} 40^{\circ} \mathrm{W}$ long. about $3 \mathrm{~km}(2 \mathrm{mi}) \mathrm{SW}$ of the soltherly portion of the Greenville Fualt eone as mapped by Herd (1977).

During field reconnaissance in the spring of 1979, local citizens told LLNL geologists of several unexplained physical events that vecurred in the areat near the southerly extension of the Greenville Foult zone. These included the experience of a property owner on Reuss Roald who stated that large cracks hud recently developed in the basement of his old house. Also, an alleged displacement of several hundredths of an ineh in the power line alignment across Sec. 17, T3S, R3E, based on the results of a private survey, was reported. Residents in Sec. 20, T3S, R3E strongly felt the June 21, 1977 earthquake. They reported incidents of minor damage, sloughing of stream banks, and the coincident cessation of flow of Arroyo Seco Creek and several springs.

A good exposure of at strand of the Greenville Fault occurs in the Western Pacific Railroad cut in Sec, 25, T2S, R.3E. There, horizontal slickensides give evidence for strike-slip displacement. Herd
(1977) described the cut but did not show it as being on a strand of the Greenville Fault

Wight (1974) assumed a length of $42 \mathrm{~km}$ (26 ini) for the Greenville-Riggs Canyon Fault zone, based upon available regional data. He computed a maximum earthquake magnitude of 6.7 for the zone, based upon empirical fault length-rupture length-magnitude relationships developed by Albee and Smith (1966). Because of insufficient data, Wesson and others (1975) did not atlempt to characterize the Greenville-Riggs Canyon Fault zone as to atetivity.

Las Pasitas Fault. The northeast-1rending Las Postatis fault was initially mapped by Herd (1977) (see Fig. 9) based on geomorphology, air photo interpretation, a ground water barrier, and two latult exposures (one un the west bank of the Arroyo Seco) and the other in at cul along Greenville Road, about 100 feet north of the Siruth Bay Aqueduet). The Lats Positas Fault. as mapped by Herd, crosses the southern portion of the SNLL site and coincides with a break in slope separating the nearly-flat Valley floor to the north from an area of small terraces and hills to the south. Features that Herd used to establish the existence of the Las Positas Filult are concentrated in an area that extends roughiy $2 \mathrm{~km}$ northeast and southwest from SNLL.

Approximately $3.2 \mathrm{~km}$ (2 mi) northeast of SNLL, the Las Positas Faull was mapped by Herd as ending abruptly at the Greensille Fault, in an areal of obseure structure.

Herd (1977) matpped a series of strands of the Las Posilas Fault tone extending from the areat of must prominent expression southuestuard for a distance of ahout $9.6 \mathrm{~km}$ (6 mii) 10 a point ahoua 1.2 $k \pi$ ( $0.8 \mathrm{mi})$ northeast of San Antonio Reservoir. Herd's map shows the Las Positas Fault throughout this interval as being largely concealed by materials ranging in relative age from recent strean gravels to his oldest alluvial deposit (Unit Qo: $\mathbf{l}_{4}$ ). Herd's map does show a short segment of the Las Positas Fatuh zone displacing older alluvial unic Quil about $1 \mathrm{~km}$ northwest of the U.S. Veteran's Administration Hospital south of Livermore. Between about $1.8 \mathrm{~km}$ (1.2 $\mathrm{mi})$ and $3.4 \mathrm{~km}(2.1 \mathrm{mi})$ southwest of the Veteran's Hospital, Herd mapped the Las Positas Fault as separating the Plio-Pleistocene Livermore Formation from the Miocene Cierbo sandstone.

URS/Blume (1978) excalvated 10 trenches within SNLL across the postulated trace of the Las Positas Fault Locations of these trenches are 
TABLE 1. Preliminary strong motion data, pertaining to the Livermore Valley earthquakes of January 24 and January 26, 1980. (CDMG, 1980, SMIRS, 1980)

\begin{tabular}{|c|c|c|c|c|c|c|c|}
\hline \multirow[b]{2}{*}{ CINIG ( 1980 ) stations } & \multirow[b]{2}{*}{ Channels } & \multicolumn{3}{|c|}{$24 \mathrm{Jan} 1980$} & \multicolumn{3}{|c|}{$26 \mathrm{Jan} 1980$} \\
\hline & & $\begin{array}{l}\text { Distance } \\
\text { from } \\
\text { epicenter } \\
\text { (km) }\end{array}$ & I.ocation & $\begin{array}{c}\text { Peak } \\
\text { Ampl. } \\
\text { (B) }\end{array}$ & $\begin{array}{c}\text { Distance } \\
\text { Irom } \\
\text { epicenter } \\
\text { (km) }\end{array}$ & Location & $\begin{array}{c}\text { Peak } \\
\text { Ampl. } \\
\text { (g) }\end{array}$ \\
\hline 1. Antinch & 3 & 21 & grnd & 0.114 & 31 & gmd & 0.11 \\
\hline \multicolumn{8}{|l|}{ 2. Briones Dam } \\
\hline l.eft-Abutment & 3 & 41 & & 0.112 & 49 & & 0.14 \\
\hline I.eft Crest & 3 & & & 0.104 & & & 0.14 \\
\hline Center Crest & 3 & & & 0.116 & & & 11.116 \\
\hline 3. Capitola Fire Stution & 3 & 95 & grnd & 0.112 & 89 & & $\mathbf{b}$ \\
\hline \multirow[t]{2}{*}{ 4. EI Cerrito, Capwedls } & 6 & 45 & grnd & 0.12 & 54 & grnd & 0.02 \\
\hline & & & roof & 0,02 & & roof & 0.03 \\
\hline 5. Fremont, Mission San Jose & 3 & 36 & gend & 0,16 & 3.3 & grnd & 0.16 \\
\hline 6. Halls Valley & 3 & $\mathbf{5 5}$ & ernd & 0.014 & 45 & & $\mathbf{b}$ \\
\hline 7. Hayward, AlPEEL. BE. & 3 & 30 & gend & 0.118 & 31 & ernd & 0.08 \\
\hline \multirow[t]{2}{*}{ 8. Hayward, Cal. State Univ. } & $\mathbf{3}$ & 31 & grnd & 0.14 & 31 & grnd & 0.116 \\
\hline & 13 & & roof & 0.15 & & tovi & 0.20 \\
\hline 9. Lexington Dam-Ahutment & 3 & 73 & & $\mathbf{b}$ & 66 & & b \\
\hline Lefl Crest & 3 & & & 0.02 & & & b \\
\hline Right Crest & 3 & & & 0.112 & & & b \\
\hline \multirow[t]{2}{*}{ IIT. Oakiand, Calrus Bldg. } & 8 & 33 & grnd & 0.02 & 37 & grnd & $\mathbf{0 . 0 2}$ \\
\hline & & & roof & 0.07 & & roof & 0.12 \\
\hline \multirow[t]{2}{*}{ 11. Oakland, Title \& Trust Bldz. } & 6 & 48 & & a & 55 & grnd & $\mathbf{0 . 0 3}$ \\
\hline & & & & & & roof & 0.09 \\
\hline \multirow[t]{2}{*}{ 12. Pleasant Hill, Citizens Sav. } & 12 & 29 & grnd & 0.013 & 39 & grnd & 0.04 \\
\hline & & & roof & 0.10 & & roof & 0.12 \\
\hline \multirow[t]{2}{*}{ 13. Redwood City, Canada College } & 6 & al & grnd & 0,02 & . 60 & gind & 0.02 \\
\hline & & & roof & 0.02 & & roof & 0.02 \\
\hline \multirow[t]{2}{*}{ 14. San Jose. Great Western Sav. } & 13 & 55 & grnd & 0.02 & 49 & gmd & 0.02 \\
\hline & & & roof & 0.05 & & roof & 0.02 \\
\hline \multirow[t]{2}{*}{ 15. San Jase, Town Park Towers } & 13 & 55 & grnd & 0.02 & 49 & gmd & 0.02 \\
\hline & & & roor & 0.07 & & rrof & $\mathbf{0 . 0 2}$ \\
\hline \multirow[t]{2}{*}{ 16. San Ramon. Eastman Kodak } & 6 & 16 & grnd & 0.15 & 21 & gmd & 0.28 \\
\hline & & & roof & 0.24 & & roof & 0.47 \\
\hline 17. San Ramon, Fire Station & 3 & 19 & grnd & 0.14 & 24 & grnd & $\mathbf{0 . 0 5}$ \\
\hline \multirow[t]{2}{*}{ 18. Saratoga, West Valley Coll. } & 11 & 68 & grnd & 0,02 & 61 & ernd & 0.02 \\
\hline & & & roof & 0.16 & & roof & 0.02 \\
\hline \multirow[t]{2}{*}{ 19. So. S. F., Kaiser Hospt. } & 11 & 59 & grnd & 0.02 & 63 & grnd & 0.02 \\
\hline & & & root & 0.13 & & roof & 0.11 \\
\hline 20. Tracy & 3 & 33 & grnd & 0.09 & 26 & & $\mathbf{a}$ \\
\hline \multirow[t]{3}{*}{ 21. Walnut Creek, Fidelity Sav. } & 3 & 26 & gmd & 0.03 & 36 & grnd & 0.05 \\
\hline & 13 & & grnd & 0.03 & & grnd & 0.05 \\
\hline & & & roof & 0.17 & & roof & 0.21 \\
\hline
\end{tabular}

Mot operating.

biot triggered. 
TABLE 1. (Continued.)

\begin{tabular}{|c|c|c|c|c|c|c|c|}
\hline \multirow[b]{2}{*}{ CDMG (1980) stations } & \multirow[b]{2}{*}{ Channels } & \multicolumn{3}{|c|}{24 Jan 1980} & \multicolumn{3}{|c|}{26 Jen 1980} \\
\hline & & $\begin{array}{c}\text { Distance } \\
\text { from } \\
\text { epicenter } \\
\text { (km) }\end{array}$ & Lacation & $\begin{array}{c}\text { Peak } \\
\text { Ampl. } \\
\text { (g) }\end{array}$ & $\begin{array}{l}\text { Distance } \\
\text { from } \\
\text { epicenter } \\
\text { (km) }\end{array}$ & Location & $\begin{array}{c}\text { Peak } \\
\text { Ampl. } \\
\text { (R) }\end{array}$ \\
\hline \multicolumn{8}{|c|}{ Temparary stations installed after January 24,1480 : } \\
\hline 1. Conta Loma & 3 & & & & 27 & grnd & 0,113 \\
\hline 2. Fagundes Ranch & 3 & & & & b & grnd & 11,25 \\
\hline 3. Margan Territary Park & 3 & & & & 9 & arnd & 0.27 \\
\hline \multicolumn{8}{|l|}{ SNIIRS (1980) } \\
\hline 1. Livermore VA Hospilul & 3 & 20 & grind & 0.17 & & & \\
\hline 2. Dil Valle Dam & 3 & 2.3 & $\begin{array}{l}\text { the } \\
\text { crest }\end{array}$ & $\begin{array}{l}0.26 \\
0.21\end{array}$ & & & \\
\hline $\begin{array}{l}\text { 3. Genural Electric } \\
\text { Corp., Vullecitus }\end{array}$ & 3 & 2.3 & grnd & 0.11 & & & \\
\hline
\end{tabular}

shown in Fig. 30. URS/Blume found evidence suggestive of faulting in some trenehes but not in others. Geophysical and trenching investigations on property approximately one-half mile southwest of SNLL produced data that suggested faulting and provided evidence that strata tentatively correlated with the Livermore Formation had been displaced. (Judd Hull and Associates, 1977; Carpenter, 1977).

To obtain more data concerning the Las Positas Fault, LLNL geoscience personnel performed an extensive field study. Areas investigated are shown in Fig. 17. Locations of detailed exploration are shown on Figs. 18 and 31. Elements of the investigation were as follows: detailed mapping of the Greenville Road cut; removal of overburden and enlargement of the Arroyo Seco outcrop; and excavation of three exploratory trenches. Trenches E-1 and E-6 were dug in the southeast portion of LLNL where vague air photo lineaments trending subparallel to the mapped trace of the Las Positas Fault had been noted during preliminary phases of the LLNL investigation, and by others (Hull, 1977). Locations of trenches E-1 and E-6 are shown in
Fig. 18. Detailed logs and summary deseriptions of the trenches are included in Appendix $F$ (Volume II) as Figs. F-1 and F-7 respectively.

Exploratory Trench E-3 was excavated in alluvium northeast of Arroyo Seco creck and crossed the mapped trace of the Lals Positas Fault. The trench location is shown on Fig. 31 , and a detailed log and summary deseription are included in Appendix F (Volume II) as Fig. F-3.

Two faults were noted in the enlarged Arroyo Seco creek bank exposure (see Fig. F-12 in Volume II). These faults displace the contace between northwest-dipping beds of the Livermore Formation and an overlying terrace deposit (Qoal of Herd, 1977). Along the northwesterly fault. younger terrace deposits (Qoa??) are juxtaposed against highly disturbed gravels derived fron unit Qou3. However, as the contact between the two units is not visibly faulted, it is unclear whether the Qua2? unit formed by deposition against an erosional surface (including a fault scarp) or whether the unit has been displaced by faulting. The southerly fault has offset the erosion surface 


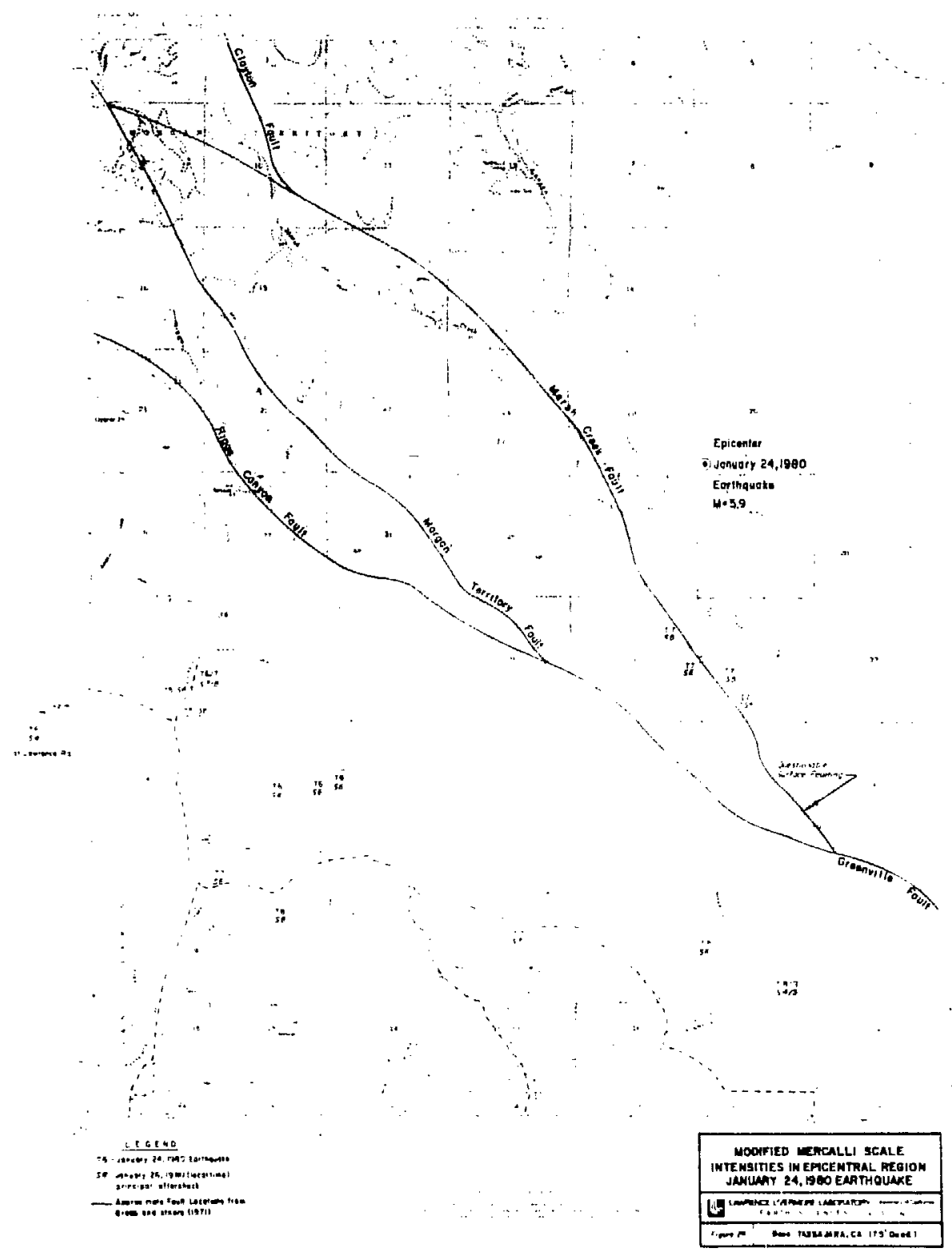

FIC. 29. Map showing intensities in the epicentral region of the January 24, 1980) earthquake in the Livermore Valley. Letter-digit combinations (e.g. T4) that appear on the map are to be interpreted as follows. The letter $T$ indicates the apparent intensity during the Thursday. January 24 earthquake and the letter $\mathbf{S}$ indicates the apparent intensity during the aftershock on Saturday, January 26. The associated digit indicates the modified Mercalli seale intensity experienced (Compiled by R. Lake). 


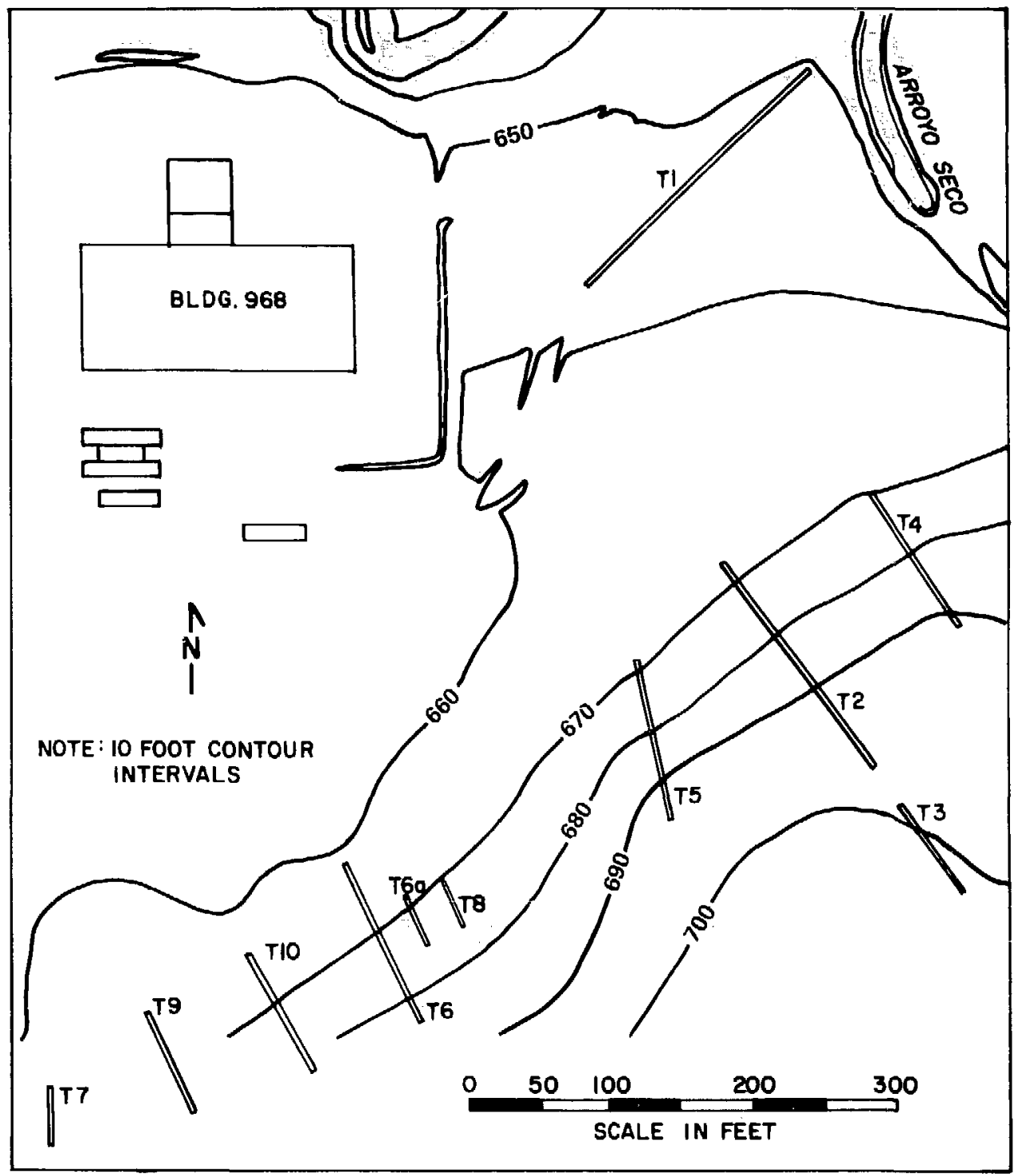

FIG. 30. Site plan showing URS/Blume and Associates' exploratory trench locations on SNLL property (modified from URS/Blume and Associates, 1978). 


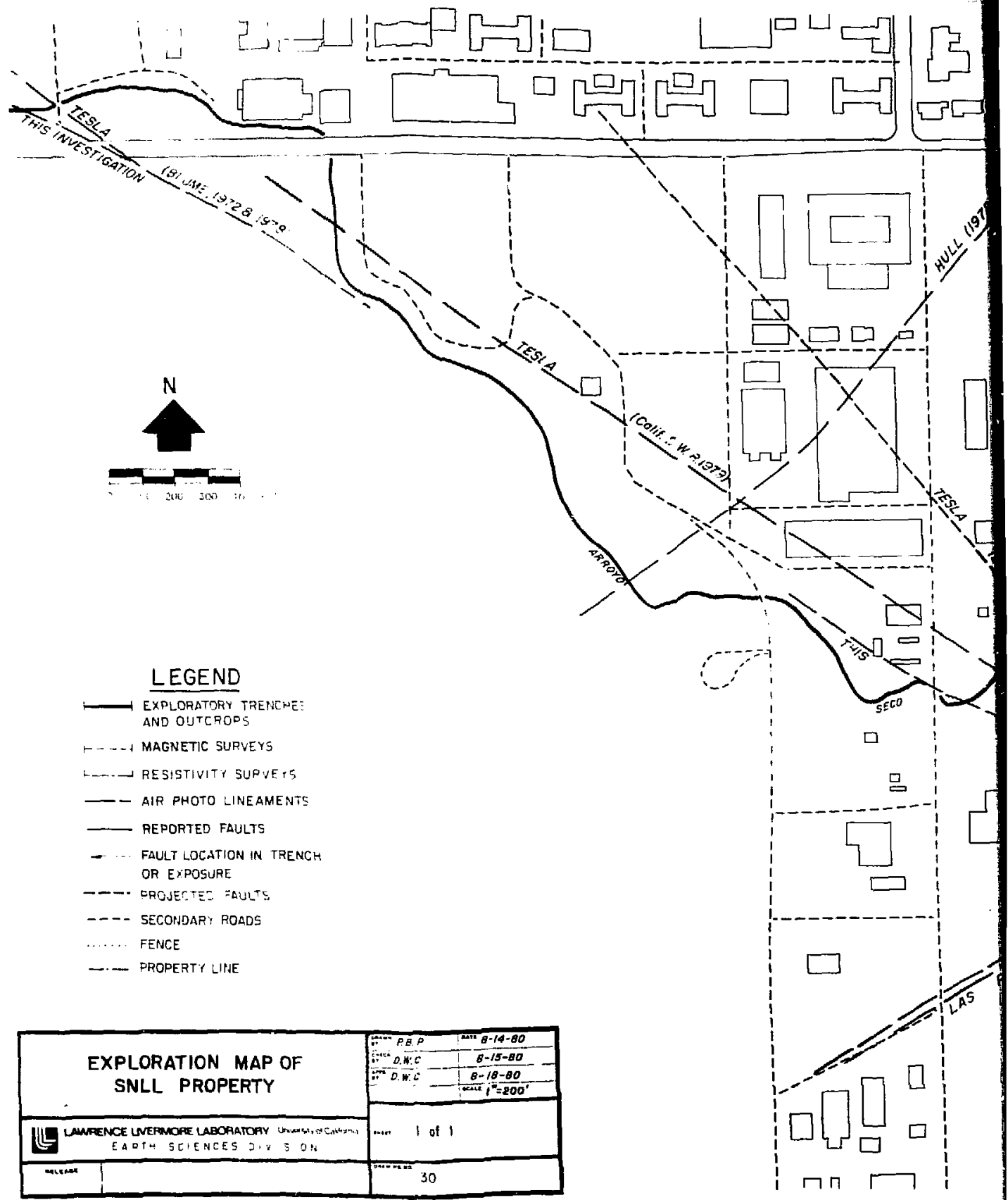

FIG. 31. SNLL site map showing locations of postulated faults, airphoto lineaments, excavations studied, and geophysical surveys made. 


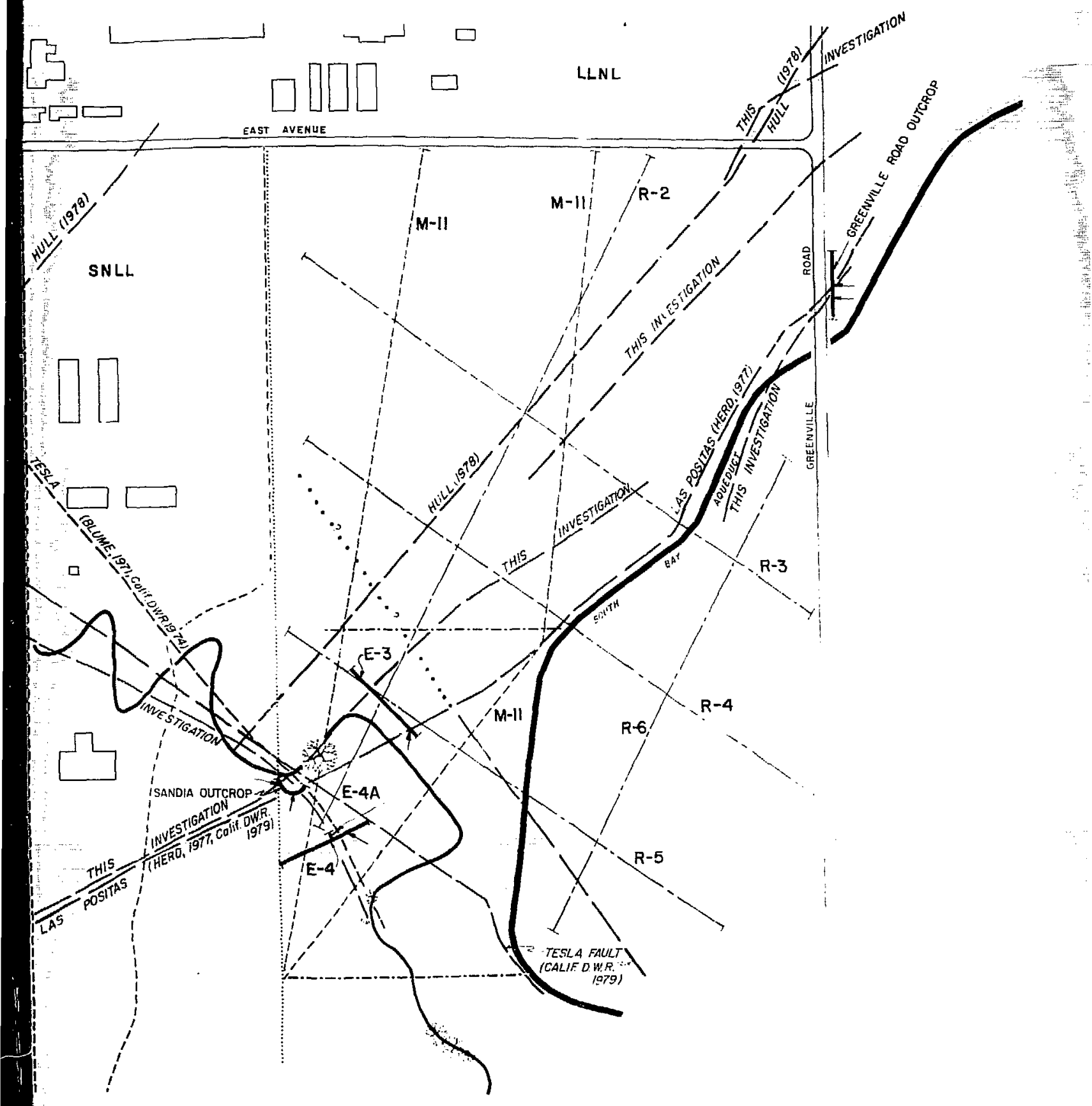


developed atross the dipping Livermore Formation beds by about one foot. Material overlying the erosion surface consists of remnants of alluvial unit Qua3 and colluvium; these materials appear at least in part to hatve been displaced as well.

Both faults strike northeast and dip near vertical. Faint slickensides preserved on the southerly fatult plane plunge $25^{\circ}$ northeast, indieating oblique but dominantly strike-slip movement.

The southerly fault was observed by Herd in 1977. The falult further to the northwest was not visible at the time of Herd's mapping. Both faults observed oceur within an approximutely $50 \mathrm{ft}$ wide zone coincident with the slope break across the southern portion of the SNLL property.

Trench E-3, excavated about $75 \mathrm{ft}$ northeust of Arrovo Seto Creek (Fig. 31), encountered an approximately $20 \mathrm{ft}$ wide zone of faulting at the hill fromt near its southerly end. The faulting is believed to be associated with the Las Positas Fauft zone. Displacement of alluvium (probably Qoin) against steeply dipping Livermore Formation beds was observed in trench E-3. A wood sample obtained at a depth of $1 \mathrm{ft}$ in Trench E-3 has been dated by the ${ }^{14} \mathrm{C}$ method all $17400 \pm 250$ yr (Robinson, 1980). The alluvial unit from which the wood sample was obtained calunot be directly traced to the fault exposed in Trench E-3. However, correlative and overlying alluvium traceable to the fault has been displaced, thus indicating movenent at less than $17400 \pm 250 \mathrm{yr}$. Much of the displaced alluvium has been altered by hydrothermal fluids or natural gas in a zone extending roughly $120 \mathrm{ft}$ north from the faulted section. However, a pocket of young appearing, unaltered alluvium abruptly terminates along a 6-in, step within the fault zone, suggesting minor late Pleistocene or Holocene movement. Colluvial soils overlying the fault zone are thickened but have not been displaced. Figure F-3 (Volume II) includes a detailed drawing of the fault zone seen in exploratory Trench E-3.

Ambiguities exist at the Greenville Road cut site (for location see Fig. 31). A number of small faults cut probable Livermore Formation beds. A one foot displacement of topsoil appears to have occurred along at least one of them. The individual small faults strike from about $\mathrm{N} 35^{\circ} \mathrm{W}$ to $\mathrm{N} 73^{\circ} \mathrm{W}$ and dip variously northeast and southwest. These small faults were seen by Blume (1972) and were regarded as evidence for the location of the Corral
Hollow or Ramp Thrust Fault zones. A detailed log of the Greenville Road cut is included in Appendix $\mathrm{F}$ (Volume II) as Fig. C-13.

A zone of highly fractured claystone containing pods of greenish clay strikes about $\mathrm{N} 80^{\circ} \mathrm{E}$ in the Greenvilie roadcut (Sta. 1+10). Colluvial soils (Unit 15) are thicker north of the fracture zone than south of it, and a gravel horizon in the hase of the colluvium north of the shear is terminated along a line that strikes $N 35^{\circ} \mathrm{E}$ across Greenville Road. The line of termination coincides with the fracture zone on the east side of Greenville Road but no evidenee for faulting, such as slickensides or pebbles upturned relative to bed ding planes, ean be seen allong it. The gravel bed could not be identified south of the fracture zone.

Two of the northwest-trending small faults terminate against the northeast-trending Greenville Road fructure zone. The others daylight in the face of the roadeut; their relationship to the northeasttrending fraeture zone cannot be determined.

Abundant carbonate fills fractures in Livermore Formation mudstone and siltstone beds south of the probable Las Positas Fault exposure along Greenville Road (Fig. 31). Two samples were obtained from the carbonate and their ages determined independently. The average age of the fracture filling cirbonate is 67000 yr $\pm 10-20 \%$. This is much younger than the minimum estimated age for the Livermore Formation (Herd and Brabb, 1980). Therefore, the carbonate is clearly secondary and fills fractures in the Livermore Formation that were created by movements along the Las Positas Fault. The most probable explanation for formation of the carbonate is the presence of a groundwater barrier along the fault. South of the fault the barrier forced groundwater to the surface, leading to carbonate precipitation.

Most of the carbonate-filled fractures show no evidence of movement subsequent to carbonate precipitation. However, some slickensided carbonate is present and there is local evidence of offset of colluvium that is demonstrably younger than the carhonate filled fractures. Therefore, some movement has doubtless occurred along the Las Positas Fault in the Greenville Roud area since carbonate formation.

As shown in Fig. 18, several vague airphoto lineaments subparallel to the Las Positas Fault were identified as crossing the southeastern portion of 
LLNL (Hull, 1977; this investigation). Exploratory trenches E-1 and E-6 were excavated across these vague lineaments.

As discussed earlier, exploratory trench E-1 exposed two well developed soil proliles within later Pleistocene alluvial deposits. The lower profile was dated at approximately $115000 \mathrm{yr}$ by the ${ }^{230} \mathrm{Th} /{ }^{234} \mathrm{U}$ method (see Appendix $\mathrm{C}$ ). Note that the date obtained represents a minimum age for the material exposed in Trench E-I because the alluvium in which the soil profile develops must be deposited und a period of geologic stability must exist before a closed system carbonate can form. No evidence of fuulting was found in Trench E-I.

Exploratory trench E-6 was excavated in late Pleistocene alluvial deposits mapped by Herd (1977) as Qoal2. The ${ }^{230} \mathrm{Th} / 234 \mathrm{U}$ age for the well-developed palcosol exposed in Trench E-6 is 17000 yr. Remnants of an older paleosol were found in Trench E-6 but did not yield carbonute suitable for dating. No evidence of faulling was found in Trench E-6.

None of the aftershocks of the January 24, 1980 earthquake were near the main portion of the Las Positas Fualt zone mapped by Herd (Cockerham and others, 1980). However, a number of aftershocks do plot near a subparallel fault mapped by Herd (1977) approximately $4 \mathrm{~km}$ $(2.5 \mathrm{mi})$ to the southeast. Cockerham and others (1980) indicate that the focal mechanisms shown by these aftershocks are consistent with the left-lateral strike-slip displacement postulated by Herd as occurring along the Las Positas Fault zone.

During their studies following the January 24 , 1980 earthquake, Bonilla and others noted concentrations of fractures across roads in the vicinity of the Las Positas Fautt, Locations of observed fracture concentrations are shown in Fig. 32; descriptions of the sites are included in Appendix $E$.

The USGS regarded the fractures at locations 34 and 35 as evidence of sympathetic motion along approximately $1.1 \mathrm{~km}(0.7 \mathrm{mi})$ of the Las Positas Fault zone. Fractures at locations 33 and 36 were regarded as of non-tectonic origin.

LLNL geologists observed several fructures in an SNLL road at location $X$ on Fig. 32. These fractures are located about 300 it south of where the Las Positus Fault is mapped across the road; no fracturing was noted at the postulated fault crossing.

Fractures noted at locutions 33 through 36 and at location $X$ are similar to fractures in asphalt pavements at a number of locations in the eastern
Livermore Valley that experienced strong ground shaking during the January 24 and 26, 1980 earthquakes. Siles of such pavement fractures include the Springlown subdivision north of Livermore, segments of Ralymond Road north of Springtown, and the northerly frontage roud north of 1-580-for at least $2000 \mathrm{ft}$ southwest of its intersection with Greenville Rd. Similar cracks also cross Morgan Territory Road in southern Contra Costa County near the mapped intersection of the Greenville and Marsh Creek Faults: the USGS did not postulatc surface fiulting at this location.

Figure 33 shows the zone of fracturing dlong $S$, Vasco Road at location 35 identified in Fig, 32. Fracture $E$ is of particular interest since it is the only fracture that crosses $S$. Vasco Road and since it consists of a series of en-echeion segments that may reflect shear. The pattern of fracture segments at fracture $E$ has been interpreled as evidence for leftlaleral strike-slip displacement of about $0.5 \mathrm{~mm}$ (Bonilla and others, 1980). However, the fractures shown at location $\mathrm{E}$ (Fig, 33) show a "left-stepping" pattern and therefore suggest apparent right-lateral motion rather than the left-lateral motion interpreted from them by the USGS.

Towse (1980) has questioned the interpretation that features observed along the hill front across SNLL are the result of tectonic fauiting. He stated that other possible hypotheses must be seriously considered before the tectonic fault hypothesis can be accepted scientifically and listed five possible explanations for the geologic features visible along the hill front near SNLL. These are presented and discussed in the following paragraphs:

Alternalive hypothesis 1: The apparent movement of the gravels is due to subjacent bedrock ficulting.

Discussion. Essentially, this is the hypothesis best supported by existing evidence. Features seen along the hill front are most probably shears that have broken to the surface through relatively weak Quaternary materials as a resull of repeated movements along a fault at depth. The location and sense of movement of the main fault at depth is presently unknown; evaluation of this hypothesis can be provided only by future geologic, geophysical and seismologic studies. An important element in these studies must be the establishment of precise epicentral locations and fault plane solutions for local 


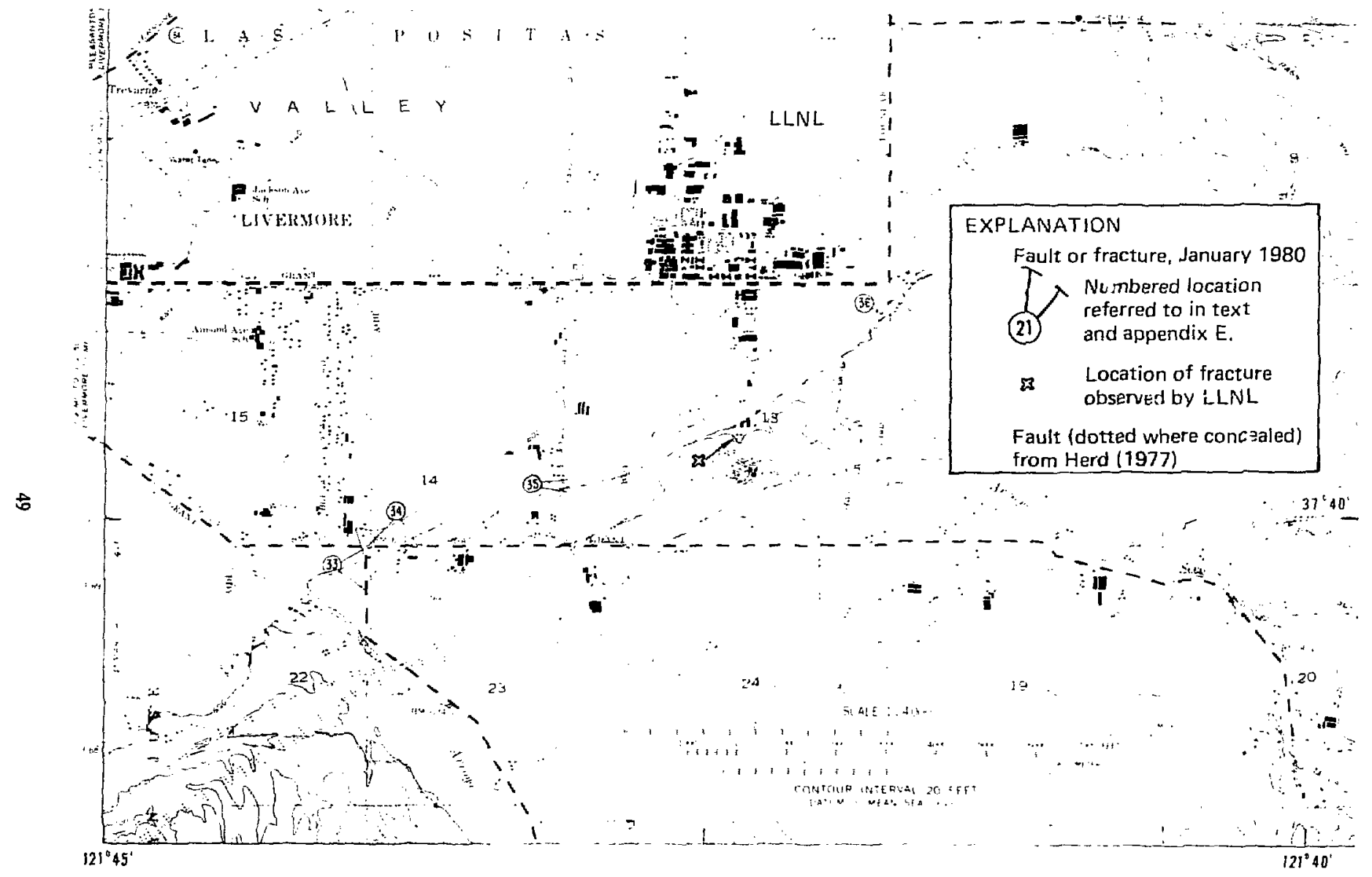

Bose from U.5. Geological Surve, $1: 24,000$

Altamont 1951 (68PA); Byron Hot SPring 1953 (68 PR)

FIG. 32. Locations of fracture concentrations along the Las Positas Fault zone (modified from Bonilla and others, 1980). 


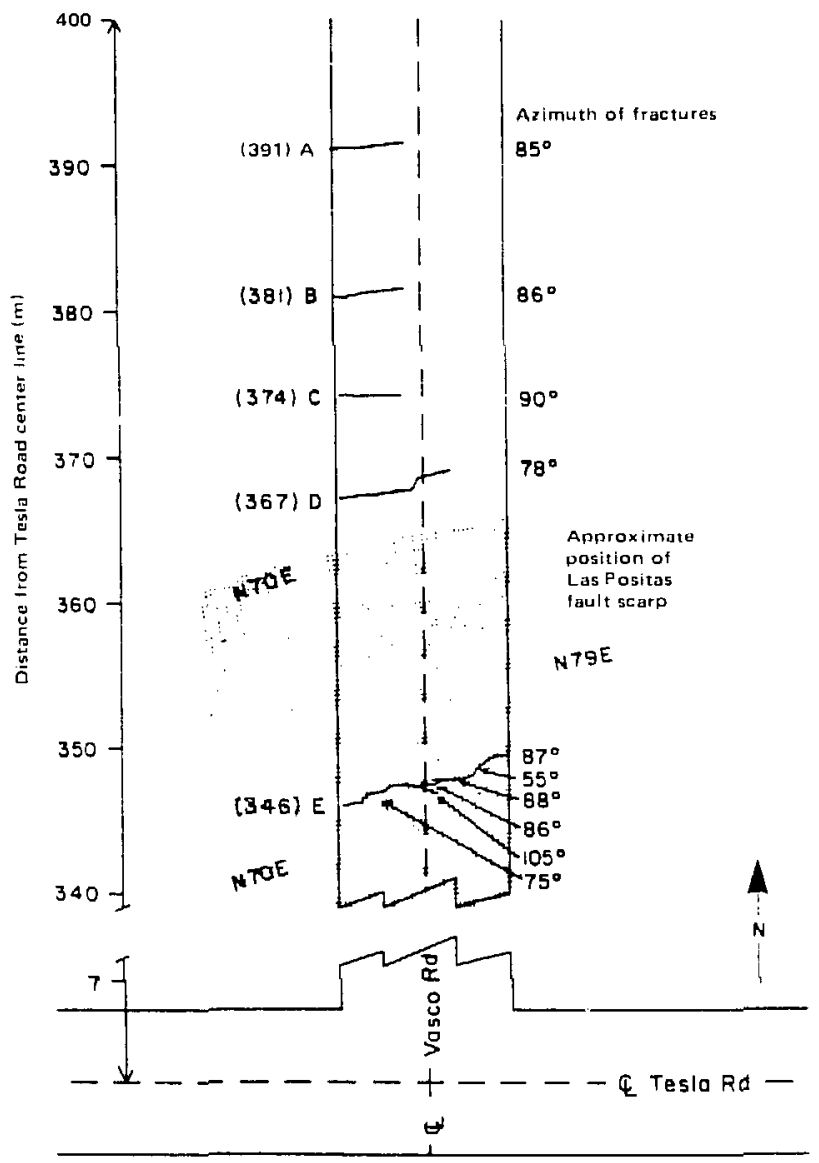

FIG. 33. Sketch map showing fractures in pavement of Vasco Rond in relation to the centerline of Tesla Road and the approximate position of the north-facing scarp of the Las Positas fault (from Bonilla and others, 1980). 
earthquakes. Several years of seismic-monitoringnetwork operations will be required before these data will be available.

Alternative hypothesis 2: The fentures are the result of faulting at some distance.

Discussion. Sympathetic movement along one fault its a result of a major earthquatke on another has been documented (see Saul, 1975, for one example). Such novements are usually a sinall percentage of the movements observed on the active fault.

The Las Positas Fault zone strikes southwest toward the Calaveras Faul, a major active regional fault system. However, the area in which the Las Positas Fault is best expressed is separated from the Calaveras Fault by a distance of approximattely 10 miles $(16 \mathrm{~km})$ and a connection between the two fauls is not definitely established.

It would appear that if the two structures were linked, the largest and most frequent movenients along the passive Las Positas Fault zone would be in the vicinity of the point of linkage and the fault zonc would have a well-defined expression in that atea.

Other faults in the region with which the Las Positas could be linked include the Gretnville, Teslia, and Livermore systems. The relationship of the Las Positas falult to these other structures requires additional study. The USGS suggested that at very minor amount of sympathetic movement along the Las Positas Fault resulted from the January 24, 1980 earthquake on the Greenville Fault zone. However, it does not seem probable that the amount of movement that appears to have occurred along the Las Positas Fault zone can be attributed solely to sympathetic response to earthquakes on other regional faults.

Alternative hypothesis 3: The features are the resull of gravity induced sliding concurrent with local episodic uplift or surface tilting.

Discussion. The puttern of shearing features along the hill front near SNLL is highly linear. Arcuate features characteristic of large landslide blocks have not been observed, and the existing scattered landslides in the area are minor superficial mudllows and slumps.

The area near SNLL presently has low to moderate relief. The pattern of Pleistocene terraces capping and surrounding steeply dipping, older Livermore Formation beds implies a Quaternary history of erosion, deposition, and locul uplift. There is no evidence to suggest that past relief was greater than presently existing relief. Evidence is lacking for a terrain compatible with large-scale landsliding or gravity block gliding. Also, as discussed above, neither the oblique slickensides preserved on some shears nor the linear en-echelon pattern of faule strands parallel to the hill front are compatible with landslide movements, In the present topographic setting, lundsliding and gravity block movements should produce low angle, northdipping shears; none hive been observed.

Alternative hypothesis 4: The features are the result of slippuge caused by streum erosion and bank collapse.

Discussion. Some of the features visible in the outcrop along the Arroyo Seco maly be attributed to local slumping and ravelling rather than to fault displacements. This is particularly true for the zone of chaotic, reddish gravel exposed in the northern part of the outcrop, inimediately south of a sequence of subhorizontally bodded gravels and silts (see Fig. F.12, Volume II). These gravels could have formed wither as a result of periodic erosion and ravelling along a stream bank or as talus along a growing filult scarp. As noted previously, the contact between the chaotic gravel and the bedded sequence is not visibly faulted.

Parts of the stepped contact between the terrace deposits (Qoil 3 of Herd, 1977) could be attributed to slumping in response to stream erosion except that the associuted shears persist at depth in the Livermore Formation. These shears cut the entire outcrop, which is approximately $6 \mathrm{~m}(20 \mathrm{ft})$ deep, with a near-vertical dip. As stuted previously, a terrain of much greater relicf than exists now, or is believed to have existed, would be required to cause the known shears through erosion effects.

Oblique slickensides preserved on the southerly fracture in the Arroyo Seco outcrop indicate laterol shearing movement along the plane. This is not compatible with stream erosion and slumping, which should have produced an unslickensided tension crack instead of a shear plane. Also, the steepdipping, gouge-bearing contuct between tilted Livermore Formation beds and nearly Mat-lying, 
bedded alluvial deposits exposed in Trench E-3 cannot be attributed to erosion, slumping, or sliding.

Alternative hypothesis 5: The features may be some combination of these.

Discussion. Multiple causes for the features observable along the hill front near SNLL cannot be ruled out. Some offsets may be the result of either aseismic slip (tectonic creep) or sympathetic motion along the Las Positas Fault in response to the stress field created by the regional San Andreas Fault system and its major branches, such as the Calaveras Fault. As noted previously, the chaotio gravel exposed in a portion of the Arroyo Seco outcrop may be a talus that developed along a fault scarp or a tault-controlled stream bank. However, all data point to active faulting as the principal caluse of the observed reatures; other causes are at best secondary.

In addition to the alternative hypotheses outlined by Towse, the Las Positas Fault may have formed as a result of consolidation of Livermore Valley fill caused by groundwater withdrawal. Overdraft conditions have existed periodically in the Valley (Alameda County Planning Department, 1979), but principal movements are in evidence along the fault in materials much older than the historic era and are not present in potentially historic deposits, such as the colluvium exposed in Treneh E-3. Also, oblique movement such as along the southerly shear in the Arroyo Seco outcrop is incompatible with faulting caused by groundwater withdrawal, which would result in stceply dipping, normal faults that are downthrown on the Valley side to the north.

In summary, the Las Positus Fault appears to be an active tectonic feature based upon generally accepted criteria. However, as noted previously, well-defined evidence for the Las Positas Fault is restricted to an area that extends roughly $2 \mathrm{~km}$ northeast and southwest from SNLL, although Herd has mapped the fault zone as extending approximately $9.6 \mathrm{~km}(6 \mathrm{mi})$ further southwest.

Livermore Fault. The CDWR (1966) identified the Livermore Fault based on a well-defined ground-water barrier between the Livermo:e and Santa Rita subbasins. They showed three sirands of the fault passing through the western portion of Livermore (1974) (see Fig. 16). An outcrop of the easternmost strand was recognized in Oak Knoll, a hill composed of the Livermore formation and located in western Livermore. Preliminary LLNL field reconnaissance st udies disclosed another possible outcrop of the Livermore Fuult along Arroyo Road a short distance north of Marina Avenue. An air photo linteament links the locations of these two outcrops. As presently mapped, the closest approach of the Livermore Fault to LLNL is about $5 \mathrm{~km}(3.2 \mathrm{mi})$ southwest of the Laboratory.

Subsequently the CDWR (1979) excavated two exploratory trenches east of Del Valle reservoir, examined water level data obtained during the spring of 1978 in the vicinity of the postulated Livermore Fault, examined acrial photographs, and performed field mapping studies along the postulated fault trace. One well-defined groundwater barrier was detected and the fault was observed in a cut-slope north of the Del Valle reservoir spillway, in an exploratory trench, and along the shoreline of Del Valle Reservoir in the southeast $1 / 4$ Sec. II, T4S, $\mathrm{R} 2 \mathrm{E}$ (where it has been uncovered by wave erosion).

In the shoreline exposure, the fault zone is reported to consist of five parallel shears within the Livermore Formation. In the spillway cut slope, the fault reportedly juxtaposes the Livermore Formation and the Miocene Cierbo sandstone. In the exploratory trench, the Livermore Formation was displaced at two locations, but the weakly developed soil profile in colluvium overlying the Livermore Formation and the fault zone was not displaced (CDWR, 1979). Examination of the trench log published by the CDWR revealed some thickening of the colluvium over the more easterly shear exposed in the trench. A local zone of carbonate accumulation, in the base of the " $\mathrm{C}$ " horizon of the soil profile developed in the colluvium, ends at the shear.

The CDWR (1979) judged that because it cuts geologically young sediments and appears associated with moderate seismic activity, the Livermore Fault should be considered aetive.

Herd (1977) did not map or discuss the Livermore Fault, although it occurs within the area of his investigation. His map shows Oak Knoll composed of the Livermore Formation while the Arroyo Road exposure is in an area mapped as an Older Alluvial Deposit $\left(\right.$ Qoa $\left._{4}\right)$. Herd (1979) has stated that the presence of an active Livermore Fault would be inconsistent with his tectonic model for the Livermore Valley, which postulates right-lateral strike-slip movement on the Greenville Fablt, left-lateral 
strike-slip movement on the Las Positas Fault, and thrusting along the Verona Fault, which he mapped in the southwestern portion of the Livermore Valley area (sec Figs, 15 and 16 and discussion below).

Note that a portion of the groundwater barrier detected by the CDWR within Livermore Valley maly be the result of pertuhation of the upper ac)uifer beneath Livermore Valley caused by drawdown of the water table around large gravel pits located north of the Arroyo Valle between Livermore and Pleasanton (Alameda County Planning Depilrtment, 1979).

Mocho Fault. The CDWR (1966) postulated the existence of the Mocho Fatult, based on geomorphic Peatures southeast and north of the Valley, and mapped it (1974) (see Figs. 6 and 16) as extending norlhwestward from the Arroyo Mocho valley aterost eentrat Litermore and into the Tassatjaral Hills north of Camp Parks. As mapped, the fialt crosses the Mocho groundwater subbisin and is destrihed as having some elfect on groundwater levels beneath Livermore-but not further to the southeast, where the presence of thick, coarse alluvium may prevent the formation of a groundwater barrier.

There is no known surface expression of the Mocho Fiult. Geophysical studies by Cooper-Clark and Associates (1973) were inconclusive regarding its presence. Cooper-Cjark and Associates used magnetometer alnd electrical resistivity methods during their investigation. Huey (1948) and Herd (1977) mapped the areal southeast of Livermore where the Mocho Fault has been postulated, but neither showed the fault on their maps. The CDWR did not show the Mocho Fuult on its 1979 map. Air photo lineaments in the Tassajara Hills north of the Livermore Valley, previously ascribed to the Mocho Fault, were regarded by the CDWR in its 1979 report as a portion of the Livermore Fault zone.

Parks Fault. The near east-west trending Parks Fault as postulated by the CDWR (1966) was based on changes in water levels and quality. The postulated fault occurs in the northwestern Livermore Valley (see Figs. 15 and 16) and separates the Dublin and Camp subbasins on the north from the Bernat and Amador subbasins to the south. The CDWR stated that there was no surface evidence for the Parks Fault but that the fault appears to offset Quarternary alluvium in the subsurface and strongly influences groundwater movement near it.
The CDWR did not include the Parks Fault on its 1979 map.

Patterson Pass Fault. Huey (1948) (see Fig. 5) mapped the Patterson Pass Fault in the Altamont Hills northeast of LLNL. He showed it as a bedrock structure branching eastward from the Greenville Fault. Ficld reconnaissance by LLNL geologists indicates that this fault may merge with or be truncated by the Greenville Fault. It could also be a part of the Tesla Fault system because it appears to merge with this system in the SE 1/4 Sec. 29, T3S, R4E. The surface expression of this fault is postulated on the existence of springs along Patterson Pass Road in Sec. 10, T3S, R3E. Near a power line in the north half of the section, its location appeitrs to be marked by a low, north-facing scarp. Huey (1948) mapped the Patterson Pass Fault northwest ward from this location to a junction with the Greenville Fatult in Sec. 5, T3S, R2E. However, during lield reconnaissance, it was not possible to trace the fault on the ground northwest of Sec. 10.

The CDWR (1979) stated that the l'atterson Patss Fault branches from the Carnegie Fault in Corral Hollow and extends northwest $13 \mathrm{~km}(8 \mathrm{mi})$ to an apparent junction with the Greenville Fitult (see Fig. 11). The CDWR noted that both the Patterson Pass Fault and the Greenville Fault show pronounced horizontal components of movement and steep dips, but they are upthrown on opposite sides. Because of apparent linkage with the Greenville Fault and seismic activity along its trace, the Patterson Pass Fault was regarded as active by the CDWR.

Pleasanton Fault. The Pleasanton Fault was mapped by the CDWR $(1966,1974)$ in the western Livermore Valley, based on a groundwater barrier and air photo interpretation. The postulated fault location is shown on Figs. 15 and 16. The fault was delineated north of I-580 on aerial photographs, but its extension south across the Livermore Valley toward Pleasanton was based on perceived groundwater effects.

Reports of evidence for tectonic creep along the Pleasanton Fault trace led the California Division of Mines and Geology (Slosson, 1974) to zone the Pleasanton Fault as one requiring geologic studics prior to the issuance of building permits for structures in its vicinity. Subsequently Burkland and Associates (1975a) and Carpenter (1975) conducted extensive investigations in Holocene 
materials and the Livermore Formution, respectively, without finding evidence for the Pleasanton Fault along its mapped trace. Other investigators had similar results. However, Judd Hull and Associates (1977b) reported evidence for a subsurface fault approximately one-fourth mile west of the previously mapped location.

At present the location and even the existence of the Pleasunton Fault is uncertain, especially since Haltenhoff (1979) stated that air photo evidence for the Pleasanton Fault in the hills north of the Livermore Valley can be correlated witi strands of the recently discovered San Ramon Villey Falult zone. The San Ramon Valley Fault zone appears to be a local feature that does nol project toward the LLNL. The relationship, if any, of the San Ramon Valley Fault cone to litults in western Livermore Valley is presently unknown.

Ramp Thrust Faut. Blume (1972) mapped the Ramp Thrust Fault as a locul sirueture in the hills southeist of LLNL (see Fig. 7). Blume mapped the fiult from Greenville Roid southeast across Secs. 17 and 18, T3S, R3E to Cross Road, a distance of about $2.2 \mathrm{~km}$ ( $1.4 \mathrm{mi})$. They indicated that displacement of the fault is demonstrated by deep hyurocirbon exploratory wells and that evidence for surface faulting along its trace was observed. The surface faulting cited was the faulted exposure on Greenville road north of the South Buy Aqueduct (Fig. 31). This road-cut has subsequently been interpreted as an exposure of the Las Positas Fault zone (Herd, 1977; this investigation) (see Fig. $\mathrm{F}-13$ in Volume II).

Herd (1977) mapped the arta that included the Ramp Thrust Fault as defined by Blume (1972). Herd did not find evidence for the Ramp Thrust Faul, although the southeastcrly portion of the fault as mapped by Blume is roughly coincident with one of the strands of the Las Positas Fault zone as mapped by Herd. The CDWR did not show the Ramp Thrust Fault on either its 1974 or 1979 maps.

Tesla Fault. This is the northernmost segment of the Tesla-Ortigalita Fault zone. This zone is composed of many faults of varying ages and runs along the eastern flank of the Diablo Range from the Livermore Valley to Panoche Valley. The nurthernmost extent of the Tesla Fault is not presently known, although Herd (1977) showed the Tesla Fault truncated by the Greenville Fault in Sec. 34, T3S, R3E (see Fig. 9).

The Telsa-Ortigalita Fault zone is probably a part of the ancient Coast Range Thrust Fault system. As previously stated, this system appears to have ceased functioning as a major element in California tectonics during Miocene time. At that time, subduction along the Pacific Plate-North American Plate boundary was replaced by rightlateral strike-slip movement along the ancestral San Andreas Fault system.

Huey (1948) mapped the Tesla Fault northwestward across the central portion of the Tesla 15 min quadrangle as a boundary fault between the Franciscan rocks to the south and the Knoxville and Panoche Formations (Great Valley sequence) to the north. Near the east boundary of Sec. 28 , T3S, R3E he mapped the fitult as separating the Livermore Fornation fron the Miocene Cierbo sandstone. LLNL field reconnaissance in this area revealed no geomorphic feutures suggestive of geologically young movements.

To the southeast in Sec. 27, the trace of the fault in the Franciscan bedrock is difficult to determine other than by stream channel orientation. This is beciluse the Franciscan itself is often pervasively sheared and masks any fault disturbance. Thus the evidence for faulting is only weakly suggestive; in any cistse, there is no evidence for geologically recent movement. Northwest of Sec. 28, Huey (1948) mapped the Tesla Fault as buried beneath the Livermore Formation and Quaternary alluvial deposits. Field reconnaissance in this area revealed no evidence for displacement of the Livermore Formation or younger sediments.

The CDWR (1974) reported evidence for displacement of the Livermore formation and evidence of influence on groundwaler movement and quality along a projection of the Testa Fault hencath Livermore Valley. Their studies indicated possible displacement of Quaternary alluvial deposits north of I-580. A cross seetion in the 1974 CDWR report showed the Tesla Fault displacing Quaternary alluvium to within about $60 \mathrm{ft}$ of ground surface.

Cooper-Clark and Associates (1973) noted that the northwestward projection of the Tesla Fault across a proposed subdivision area about two miles north of Livermore was visible on aerial photographs as a linear contact between the Pliocene Orinda Formation and younger alluvial deposits. A distinct left-lateral jog in Collier Canyon roughly 5 miles norihwest of Livermore illigned with the projected fault trace and was cited as possible evidence for left-lateral offset along the Tesla Fault. 
Cooper-Clark and Associales (1973) reported 40-10-160-gammat varialions in magnetic intensity atcross the Tesia Fatuli north of $1-580$ als projected by the CDWR. They alsu cited indications of possible fault "creep" at two unspecified locations along the South Bay aqueduct southe ast of LLNL. Their inspections of the locations reveated that creep movement was not well delined and could be the result of unstable soil conditions in the vicinily of the presumed faull zone. Cooper-Clark and Associates statted that at one locition it recent landslide had ohviously eontributed to the cracking of the alpueduet while all the obher lacalion, pressures resulting from storm waller seepage along a drainage swale could atcoum for damage done to the alyeduct's lining.

Btume (1972) mapped three strands of the Tesial Falult system, halsed on geomorphic features and incerpretation of geophysisal data obcained by use of magnstunketer, scismic refraction, and gravity methods (sec Fig. 7). Blume (1972) stated that Strand 1 of the Tesla lialt gone had not undergone moventent since deposition of the Livermore Formation (possibly +000000 yr ago) and therefore wits not considered at potential hizard.

Blume (1972) reported that Strand 2 of the Teslit Falut is a geologically young feilture, based on geomorphic and gravi!y profile evidence. They reported an exposure of Strand 2 in a utility trench on SNL1. propery. However, this exposure also corricides with the mapped boution of the Las Pontas fault. LRS Biume : I"78) excalvaled exploritury Trench $T-1$ in illuvium across the puratulated location of Strand ? of the Tesla Fault whon SYl1 and found nes esidence of faulting.

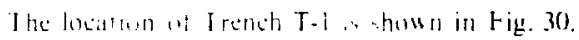

To lurther mevigate the costulated Strand 2

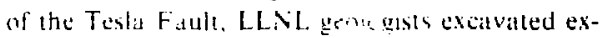
plorator! Trench E-t across the hitinped fault irace

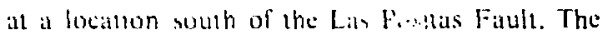
locition of Trench E-t is shown on Fig. 31. The detailed trench log and summary description of the trench are given in Appendix 1 (in Volume II) as Fig. F-t.

Trench E-4 was orienled approximalely at right angles th the mapped trace of the Tesla Falult and crossed a distinet sope break between lwo lerrace levels. The trench penctrated the deposits underlying hoth lerraces and exposed beds of the underlying Plio-Pleistacente Livermore Formation. A nurtheast trending fatule within the Livermore Formation. prohathly related to the Lits Positas Fatult zone, was encountered in Trench E-4 but no evidence for the mapped northwest trending Strand 2 of the Tesla Fault was observed in the trench.

The CDWR (1979) noted that the southernmost segments of the Tesla Fault zone are considered active but that no geomorphic evidence exints to suggest recent movement to the north. The CDWR noted that numerous earthquake epicenters plot near the Tesla Fault zone.

Strand 3 of the Tesla Fuult system was mapped by Blume (1972) (sec Fig. 7) ats a local fault in the hills within the southern portion of SNLL and nearby areas. In 1978, URS/Blune reevaluated previous evidence and removed the fault from their maps (sec Fig. 10).

Verona Fault. The C.DWR (1966) mapped the Verona Fault southwest of Pleusanton and reported evidence for displacement of the Livermore Formation as well as the existence of a groundwater harrier in alluvium where the fault crosses the narrow cianyon of the Arroyo de Laguni. The location of the Verona Fault as postulated by the CDWR is shown on Figs. 15 and 16.

Herd (1977) placed the Verona Fauit southwest of the position shuwn by the CDWR. His mapping placed the fault close to the General Electric Corporation's Vallecitos Nuclear Center, a mapping that necessitated detailed studies of the Vallecitos areil. The ensuing investigations locited the Veroni Fault essentially ats mapped by Herd and also identified several other smaller fiults in the areal. The Verona Fault and other nearby faults were found to dip at low angles. A lengthy controversy has arisen ats to whether these features are of leetonic origin or represent the surface traces of slip planes of large, degraded landslides that developed in the past along the southwest slupe of the hills northeast of Vallecitos (see Rice and others, 1979). The CDWR did not include the Veronal Faut on its 1979 map.

Williams and Valle Faults. The CDWR (1974) mapped a complex of northwest and north trending fituls within the lower slopes of the Diablo Range south and east of Del Valle Rescrvoir (see Fig. 34). The CDW $R$ did not consider these faults further in its 1974 report since they did not influence Valley geobydrology:

In its 1979 report, the CDWR stitted that the Willians Fault, the more westerly of the complex, cuts Plio-Pleistocent Livermore gravels in the Hetch-Hetchy Tunnel. This observation, along with moderate seismic actlvity adjacent to its trace. 


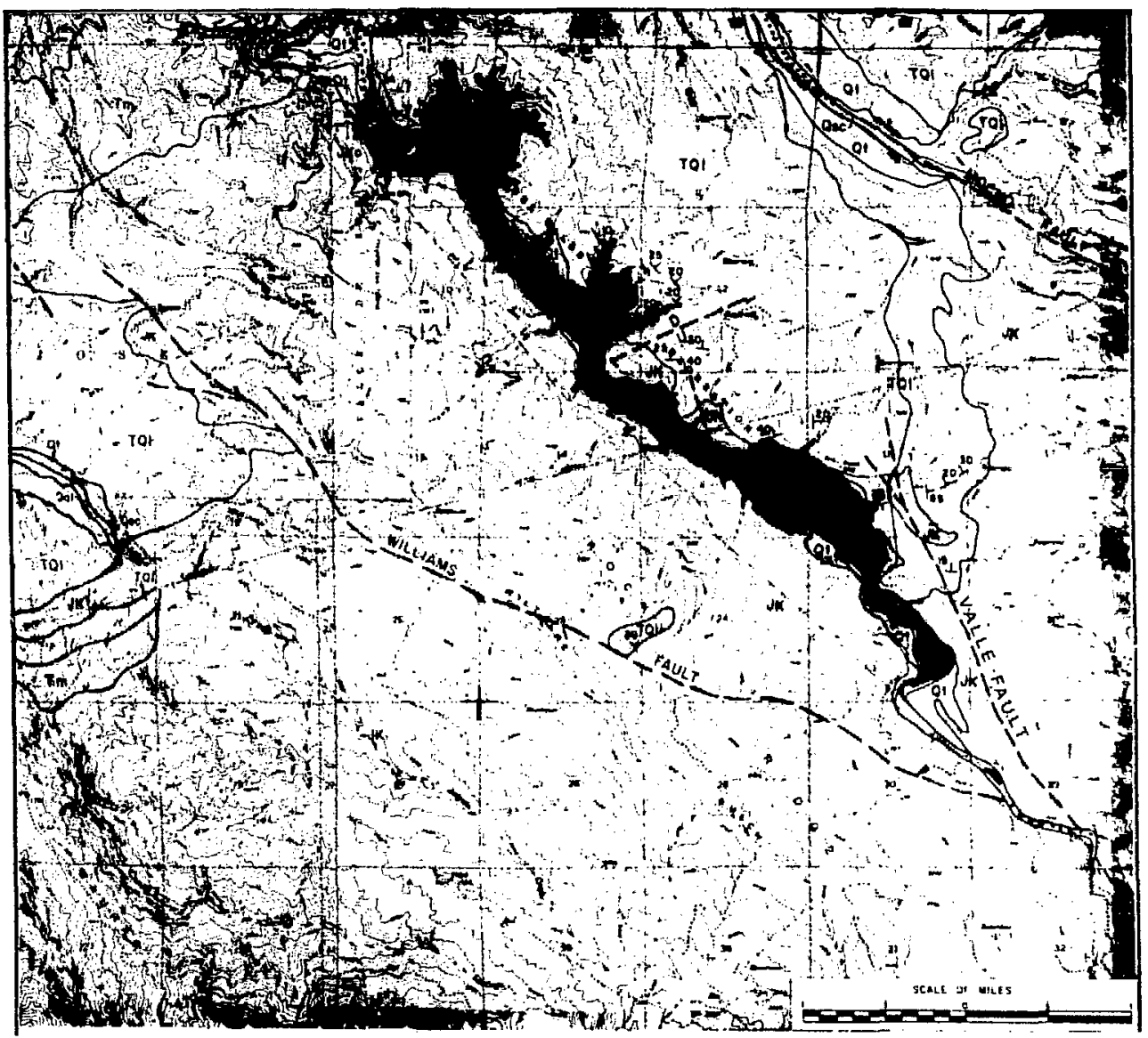

FIG. 34. Map showing locations of the Williams, Valle, and Mocho faults as mapped by CDWR (1974).

suggested to the CDWR that the Williams Fault is active.

Elsworth and Marks (1980) stated that seismologic data in the vicinity of the Williams Fault as projected north of the mapped Las Positia: and Verona Faults are not compatible $n$ it: postulated movement on the Williams Fault. South of these faults the data are poorly constrained but some could be compatible with right-lateral move- ment on the Williams Fault. They noted that seismicity in the vicinity of the southerly portion of the Williams Fault scatters widely and is distributed on numerous faults.

The log of the Hetch-Hetchy Tunnel shows the easterly Valle Fault to separate granodiorite and Livermore gravels. Since the fault cuts Quaternary sediments, it is considered active under CDWR criteria. However, the CDWR noted that only three 
small earthquakes have occurred near its trace since 1900 and that their locations were plotted with a several kilometer uncertainty.

Other Faults. The CDWR (1974) mapped several minor faults in the Las Positas Valley north of Livermore. Cooper-Clark and Associates (1973) identified seven possible minor faults in this same areil, balsed on geophysical studies and field reconnaissance. Most of these locial fitults appeared to be hranches of major faults mapped or projected into the areat.

Herd (1977) mapped several short east-west trending linults in the foothills south of the Livermore Valley. These showed evidence for displacement of the Livermore Formation. A southerly branch of the Las Posilas Fault systen was mapped allong the south side of the low hills, which include the southern part of SNLL. A well-defined air photo lineament marks this fault, and small faults displace lerrace deposits where the lineament erosices Greenville and Tesla roads. The CDWR (1979) also mapped a number of small fauls in the vieinity of Del Valle Dam and Reservoir. Several of these appear to branch from the Livermore Fault.

A considerable amount of microseismicity has been detected along the southern margin of the Livermore Valley. generally from the vieinity of Del Valle reservoir eastward (Ellsworth and Marks, 1980). Aftershocks of the January 24, 1980 Livermore Valley earthquake have also been recorded in this area (Cockerham and others, 1980). A number of these events plot in the vicinity of the short faults mapped in the area by Herd (1977).

(ieodetic Measurements. Benchmark surveys and triangulation data for various areas within and near Livermore Valley have been reviewed and anulysed by Gibson and Wollenberg (1968), Blume (1972), Alt (1979), and the CDWR (1979).

Gibson and Wollenberg (1968) detected horizontal and vertical movements across faults nlapped in northwestern Livermore Valley (see Fig. 35). Blume (1972) noted similar vertical movements near the eastern margin of the Valley (Fig. 35).

Blume (1972) interpreted data developed during their study and that developed by Gibson and Wollenberg as follows:

- Vertical ground movements change from subsidence to uplift in the vicinity of the $r_{\text {aliaveras }}$ Fault. Data indicate that the valley foor is still sub. siding while the adjacent hills are rising and that some of this differential movement is spatially related to the Calaveras Fault. It does not appear that vertical creep movements are taking place on the fault, but rather differential movements are taking place by elastic deformation in the vicinity of the fault. According to the theory of elastic rebound, these deformations and accumulated stresses would be relieved periodically by movement on the Calaveras Fault.

- At the east margin of Livermore Valley near the LLNL site, a change from ground subsidence to uplift also takes place. This change in direction of ground movements does not coincide precisely with the location of the Carnegie Fault, which is one of the boundary faults of the valley. Instead, the change appears to take place along a line parallel to and southwest of the Carnegie Fautt. The line of change passes in a northwesterly direction through the northeast corner of LLNL. This line of change coincides with the postulated location of the Doutherty Fault, a fault hypothesized through various indirect lines of evidence. Although the direction of ground movement appears to change along this presumed fault line, the general topography of the region indicates that most differential vertical movement in the area has taken place on the Carnegie Fault.

Blume (1972) made a detailed analysis of benchnark releveling data from within and near LLNL. This dala included surveys of Laboralory benchmarks as well as U.S. Coast and Geodetic Survey benchmarks as shown in Fig. 36. Movements shown for the Coast and Geodetic Survey stations are annual averages based on resurveying over a 20 year interval. Data for LLNL benchmarks were for a one year resurveying interval. Blume noted that resurveying of the LLNL benchmarks indicated higher apparent rates of movement than those calculated for the Coast and Geodetic Survey marks. No explanation for the apparent differences in movement rates could be established.

Blume (1972) noted that the area of maximum subsidence within and near LLNL appears to coincide approximately with the axis of the Livermore syncline while areas of minimal subsidence (or uplift) coincide more with the margins of the syncline. This was interpreted as evidence that the tectonic forces that initially produced the syncline are still active.

Blume (1972) noted that groundwater withdrawal could be a factor in subsidence of the Valley 


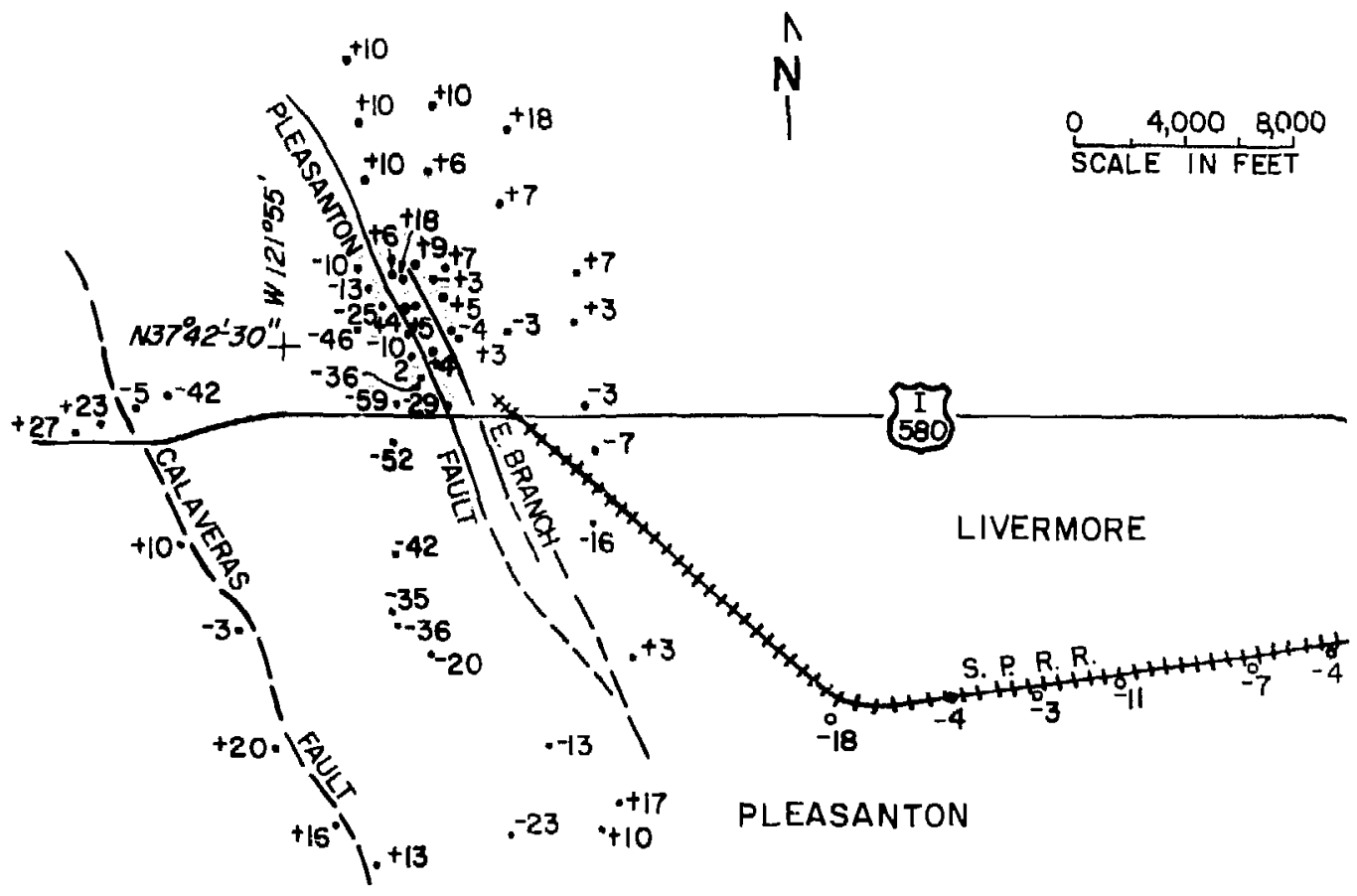

\section{LEGEND}

- U.S. COAST \& GEODETIC SURVEY MONUMENTS. VERTICAL GROUND MOVEMENT SHOWN IN THOUSANDTHS OF A FOOT PER YEAR.

- MAP NORTHWEST OF PLEASANTON FROM GIBSON \& WOLLENBERG (1968)

- mapping in central and eastern valley BY BLUME AND ASSOCIATES, 1972.

FIC. 35. Geodetic information in Livermore Valley (from Blume, 1972). 


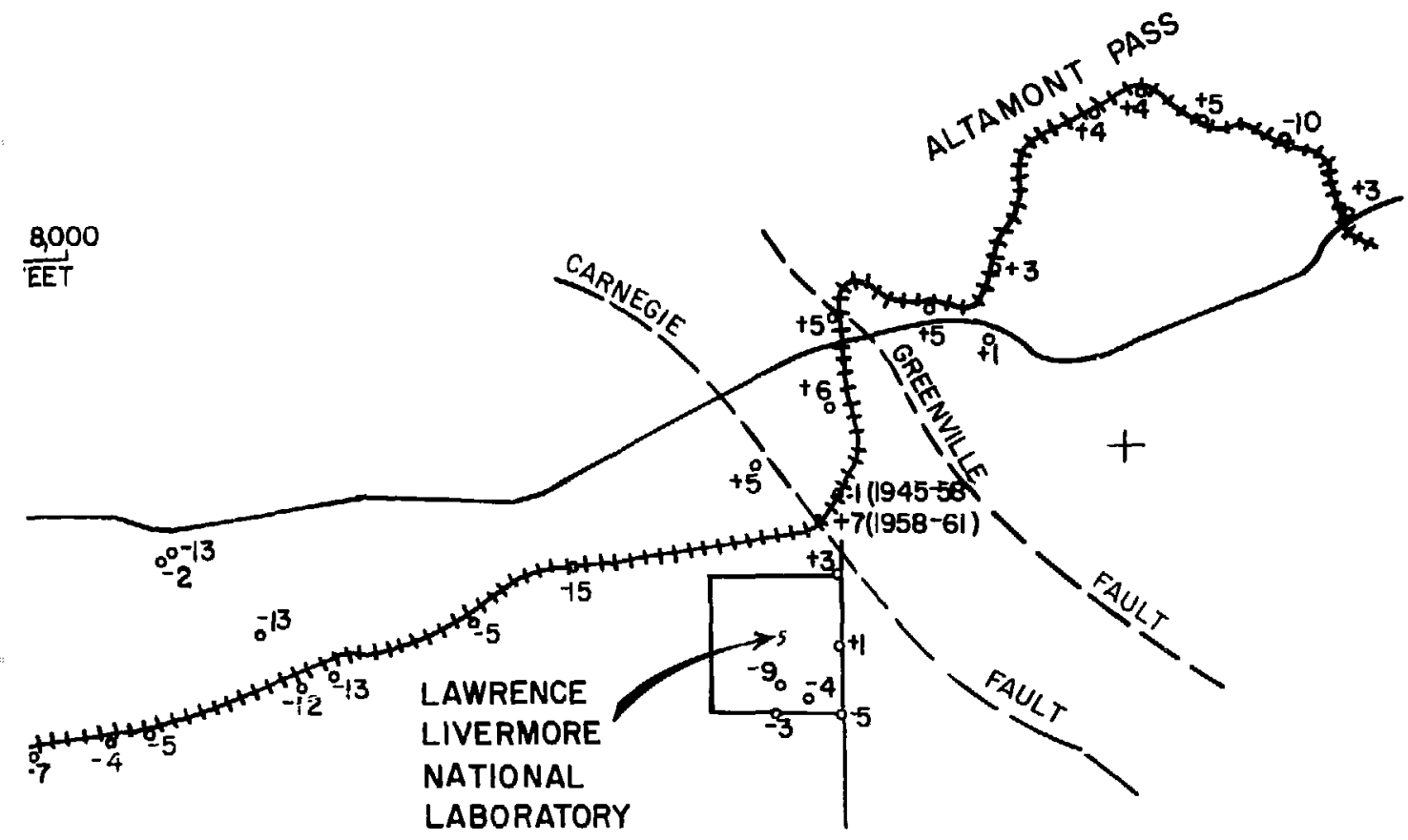




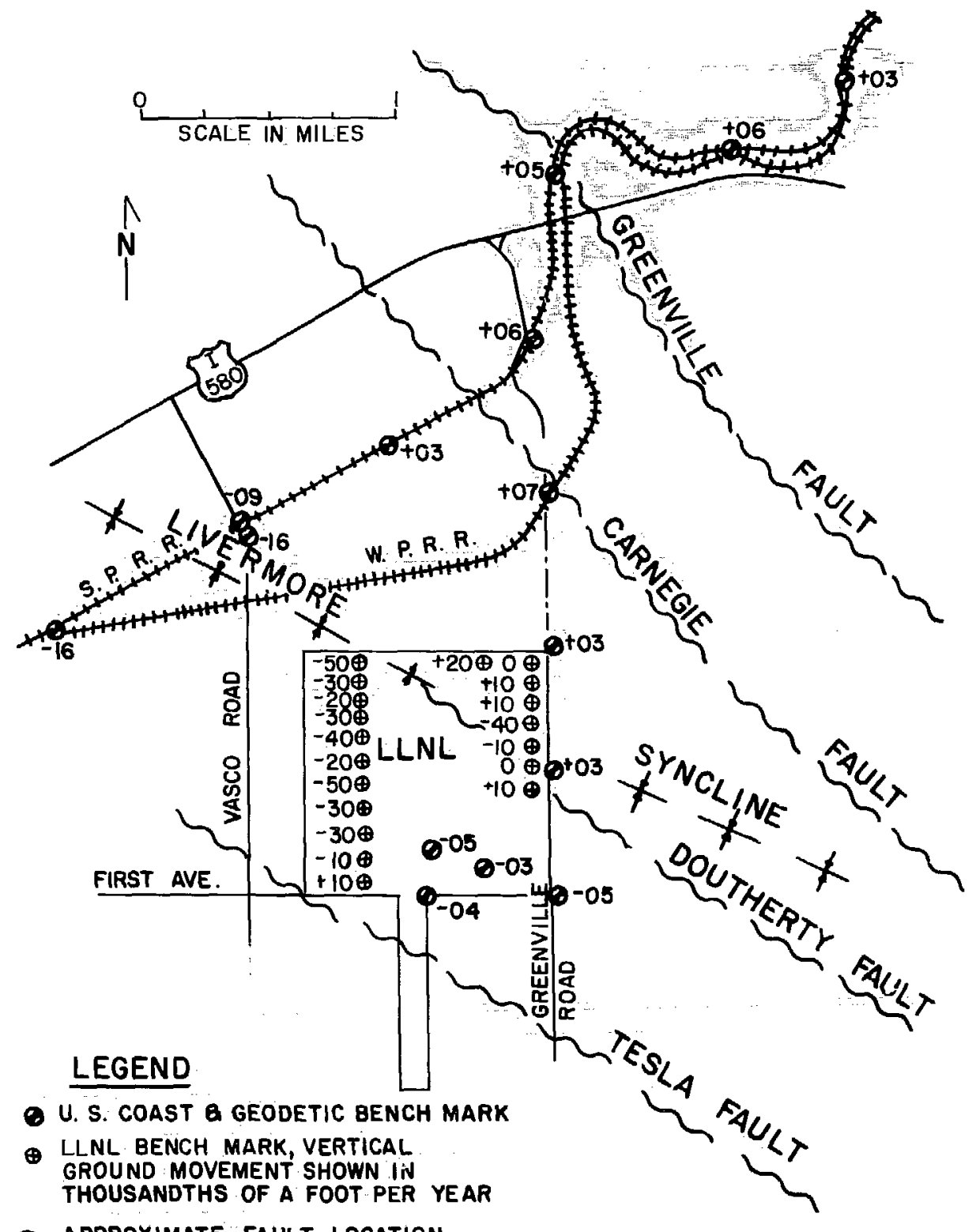

ح APPROXIMATE FAULT LOCATION

+ APPROXIMATE AXIS OF SYNCLINE IN BURIED SEDIMENTS

NOTE: FROM BLUME Q ASSOCIATES (1972)

FIG. 36. Map showing bench marks and vertical ground movement within LLNL (from Blume, 1972). 
floor. They indicated that subsidence related to groundwater withdrawal would be superimposed on the tectonic subsidence and therefore would be difficult to estimate. They expressed the opinion that such subsidence would be uniform over large areas while the observed subsidence shows considerable variability in a way which could indicate a relationship to tectonic structures. However, with respect to this opinion, it should be noted that groundwater withdrawal is not uniform throughout the Valley (Alameda County Planning Department, 1979) and therefore the potential exists for additional uncertainties in the data. It should also be noted that significant groundwater withdrawal has not occurred at LLNL itself for many years and that no major ground water withdruwals are known to be presently occurring in the vicinity of the Laboratory.

Alt (1979) reviewed the results of periodic firstorder geodetic leveling along the Southern Pacific Ruilroud line from the Niles district in Fremont to Altamont Puss eust of Livermore Valley. The latest data available to him were obtuined in 1965 and were therefore probably available to Blume in $\mathbf{1 9 7 2 .}$

Alt noted uplift of the Berkeley Hills west of Livermore Valley at a rate of 1.5 to $2 \mathrm{~mm} / \mathrm{yr}$ relative to the San Francisco Bay Plain. He reported that the area of uplift is bounded on the east by the Calaveras Fault and that there is relative subsidence east of the fault within Livermore Valley. Differential subsidence has occurred within Livermore Valley and has had a maximum subsidence rate of about $7 \mathrm{~mm} / \mathrm{yr}$ east of Pleasanton (ibid). Alt noted a gross correlation between locations of differential subsidence within Livermore Valley and reported groundwater barriers.

Alt (1979) stated that the Altamont Hills east of Livermore Valley are being $u_{p}$ lifted relative to the San Francisco Bay Plain at a rate of about 1.5 $\mathrm{mm} / \mathrm{yr}$, but he regarded this value as questionable because of a wide scatter in survey data. Alt stated that the boundary between subsidence of Livermore Valley and uplift of the Altamont Hills is at the approximate mapped location of the Carnegie Fault.

Alt (1979) noted that an analysis of secondorder leveling data along lines extending south from Livermore Valley indicates a relatively uniform northward tilt.

The CDWR (1979) noted a strong correlation between subsidence in the area southwest of Patterson Reservoir and withdrawal of oil from the Livermore oil field. The CDWR data shown in Fig, 37 were bused on (usially) annual resurveys of a benchmurk array installed in 1969.

The CDWR (1979) detected a slight reversal in the trend of some benchmarks ( $2 \mathrm{~mm}$ maximum) during a 1977 resurvey. They suggested that the anomalous elevation changes may have been caused by the June 2 l, 1977 earthquake ( $M=4.7$ ), which occurred about $3 \mathrm{~km}$ ( $2 \mathrm{mi})$ south of Patterson Reservoir. The CDWR stated that its 1978 resurvey showed that the original trend had resumed at all except a few benchmarks.

The cumulative contours drawn by the CDWR include the northeast corner of the LLNL site (see Fig. 37) and show the maximum amount of subsidence within LLNL as less than $10 \mathrm{~mm}$. The area of subsidence mapped by the CDWR was also shown by Blume (1972) but was shown as an area of no change or slight uplift (sec Fig. 36). Since both the CDWR and Blume were working during the same period in the early 1970 's, reasons for their differing results are unclear.

\section{LLNL SITE GEOLOGY}

\section{STRATIGRAPHY}

LLNL is underlain by a thick sequence of late Tertiury and Quaternary alluvial deposits and by poorly lithified rocks of predominantly continental origin. Huey (in Blume, 1972) reported that hydrocarbon exploratory well P-1, located near the southwest corner of LLNL, penetrated approximately $2420 \mathrm{ft}$ of these materials before reaching "basement" rocks of the Franciscan assemblage.

Helley and others (1972) mapped most of the LLNL site and the northeastern portion of the adjacent SNLL property as being underlain by Older Alluvial Fan Deposits (Qof) (Fig. 13). These 


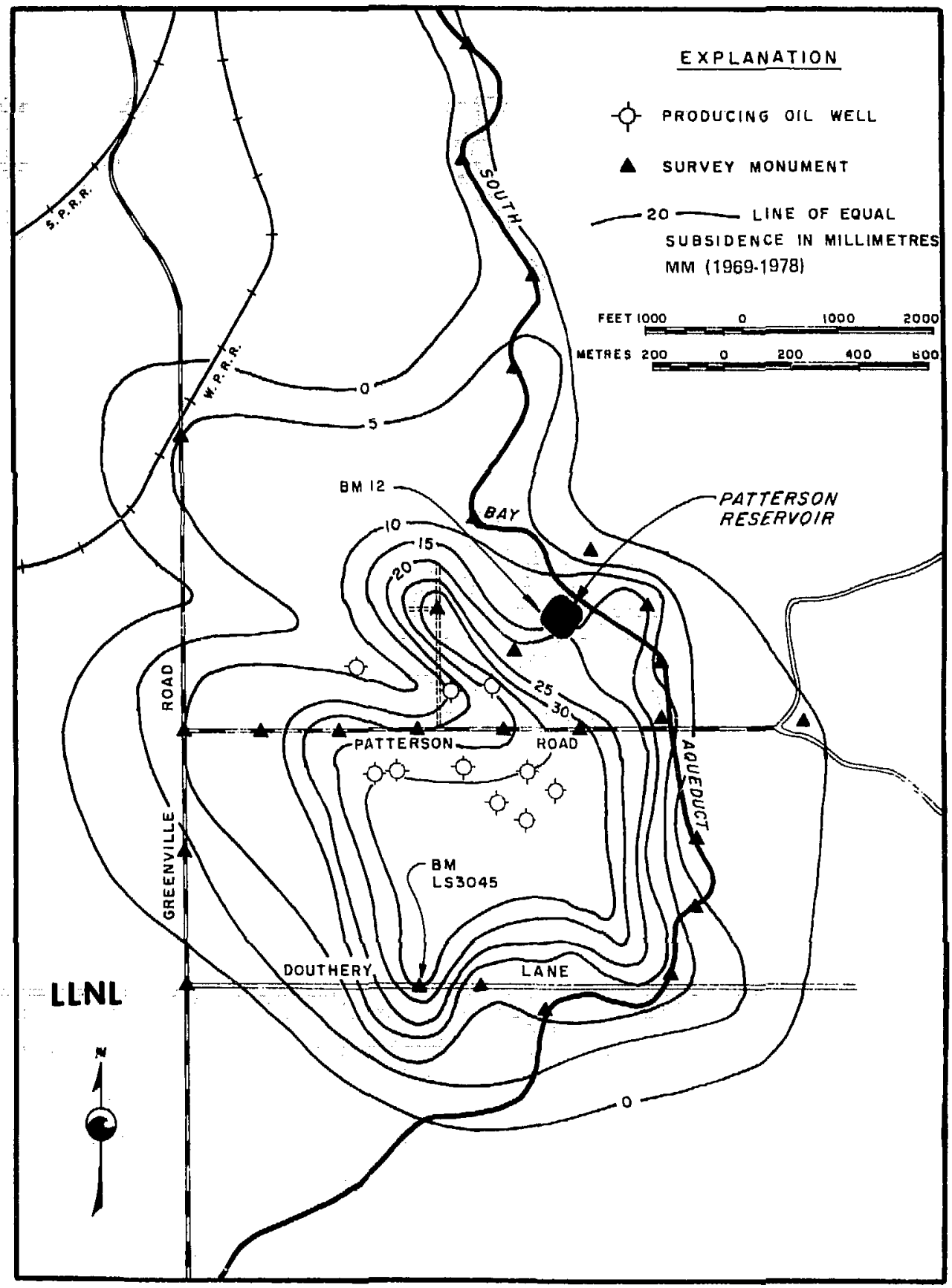

FIG. 37. Areal subsidence in the vicinity of Patterson reservoir (from CDWR, 1979). 
materials were described (on the map legend) as

"weathered, weakly consolidated, poorly sorted silt, sand, and gravel (generally fine-grained in northeastern Livermore Valley owing to derivation from friable sandstone bedrock). Less permeable and more poorly drained than younger alluvial fan deposits... Headward portions...incised by channels that are partly filled with younger deposits on northern bay margin and in Livermore Valley. Locally contains concentrations of continental vertebrate and invertebrute fossils,"

The southwestern corner of the LLNL site adjacent to the Arroyo Seco was mapped as Younger Alluviul Fun Deposits (QyI). These wcre described (in the map legend) as

"unconsolidated, moderately sorted, permeable fine sind and silt, with gravel becoming more abundant toward fan heads and within canyons, Forms welldrained levees which grade headward to streilm deposits on terraces cut in Qof,"

Herd (1977) remapped the eastern two-thirds of the Livermore Valley. He mapped most of the LLNL site and the northerly portion of the SNLL site as an older alluvial deposit (Qoa $)$. The central portion of SNLL was mapped as a slightly older alluvial deposit $\left(\mathrm{Qoa}_{3}\right)$. The western portion of LLNL and a small area in the northern part of the site were mapped as Recent Flood-Plain Altuvium (Qfa) while the hilly southern portion of SNLL was mapped as underlain by "The Livermore Gravels of Clark (1930)" (QT1). Herd's mupping of the LLNL and SNLL sites is shown in Fig. 9.

Herd did not provide lithologic descriptions of Recent Flood-Plain Alluvium or the Older Terrace Deposit sequences. Analysis of logs of 132 test borings made chiefly for building foundations on the LLNL site show that LLNL is underlain by alternating sequences of silts, clays, sands, and gravels. These exploratory borings are concentrated in developed portions of LLNL and range in depth from $4 \mathrm{ft}$ to a maximum of $126 \mathrm{ft}$; most range from 25 to $65 \mathrm{ft}$ in depth. The borehole logs are on file in the LLNL Plant Engineering Department oftices. Drillers' logs of several deeper (300 ft and greater) cathodic protection wells and water wells also exist. Lithologic descriptions included in these logs are rather generalized and of uncertain guality.
During trenching studies in the eastern portion of LLNL, two moderately-well developed soil profiles were observed in the near-surface portion of the alluvial sequence underlying the Laboratory and nearby areas. As discussed previously, an average age of about $19000 \mathrm{yr}$ was obtained for a soil formed within alluvium mapped by Herd as $\mathbf{Q o a}_{2}$. An age of approximately $115000 \mathrm{yr}$ was obtained for a deeper horizon.

No continuous, readily recognizable marker beds could be detected in the subsurface below LLNL. This is consistent with previous findings by the CDWR (1966). However, aggregate lithologic units consisting of predominately coarser materials, sands, and gravels, or predominately finer materials, silts, fine sands, and clays can be recognized locally.

\section{STRUCTURE}

As shown in Figs. 6, 7 and 10, various investigators have postulated faults traversing the LLNL site. Faults previously mapped as underlying LLNL are the Corral Hollow Fault (Blume, 1971; CDWR, 1974), the Doutherty Fault (Blume, 1972), and the Tesla Fault (Blume, 1972; CDWR, 1974). Air photo lineaments subparallel to the nearby Las Positas Fault zone cross the southeast portion of LLNL (Judd Hull and Associates, 1977; this investigation),

As discussed in a preceding section and in Appendix F (Volume II), exploratory trenches have been excavated across the mapped locations of the Corral Hollow and Doutherty Faults within LLNL and across the Tesla and Las Positas Faults on SNLL property. Two air photo lineaments possibly related to the Las Positas fault have also been trenched within LLNL.

No direct geologic evidence has been found within LLNL to suggest that any of the postulated faults cut alluvial deposits that have been dated as late Pleistocene, based upon soil profile development and the ${ }^{14} \mathrm{C}$ an!? ${ }^{230} \mathrm{Th} /{ }^{234} \mathrm{U}$ age dating methods. No evidence for the Tesla Fault, as mapped, was found in late Pleistocene or PlioPleistocene materials from the trench on SNLL property. Several strands of the Las Positas Fault zone were encountered in exploratory trenches and in other excavations made on SNLL property. These fault strands displace late Pleistocene alluvial 
deposits and beds of the Plio-Pleistocene Livermore Formation. No evidence for strands of the Las Positas Fault zone was found in late Pleistocene alluvial deposits exposed in exploratory trenches excavated in the southeastern portion of LLNL.
Blume (1972) mapped a local fold structure, the Livermore syncline across the northeastern portion of LLNL (Figs. 7 and 36). They presented evidence suggesting that the Livermore syncline is an area of active tectonic downwarping.

\section{SUMMARY AND CONCLUSIONS}

LLNL is underlain by a thick sequence of Quaternary alluvial deposits overlying a complex basement of Mesozoic metumorphic and late Mesozoic and Tertiary marine sedimentary rocks. The Quaternary alluvial deposits include lacustrine, alluvial fan, and stream channel deposits that accumulated in a continental environment. Rapid lateral and vertical facies changes are common within these sedimentary deposits,

The Laboratory is located in a tectonically active region. Folding and faulting of Quaternary materials and periodic seismicity support this conclusion.

Limited geodetic data suggest active downwarping of alluvial deposits beneath LLNL. However, soil profiles developed in alluvial deposits exposed in excavations and exploratory trenches within the eastern portion of the LLNL site suggest that periods of relative stability (with little net erosion or deposition) have occurred during late Pleistocene time. Motions indicated by existing geodetic data suggest downwarping along the axis of the Livermore syncline (mapped as crossing the northeastern portion of LLNL). The indicated motions do not support the existence of the Doutherty Fault as a hinge line separating areas of subsidence within the Valley from areas of uplift in the Altamont Hills to the east.

Within the Livermore Valley and adjacent areas, geologic and seismologic evidence demonstrate Helocene activity along the Calaveras and Greenville Fault zones that bound the Valley on the west and eust, respectively.

Geologic features visible along the hill front near SNLL provide evidence for the presence of the Las Positas Fault, a strike-slip fault of tectonic origin. Southwesterly displacement of the Arroyo Seco channel and some minor drainages coupled with the "right-stepping" pattern of en-echelon fault strands in the vicinity of the Arroyo Seco suggest left-lateral movement. Outcrop and trench data provide clear evidence for repeated late Pleistocene movement; Holocene movement may have occurred.

Displacements of late Pleistocene and Holocene materials have occurred along strands of the Verona Fault zone in the southwestern Livermore Valley. However, the nature of movements along this zone are unclear and controversial.

There is evidence for local displacement of Quaternary materials along the Carnegie, Livermore, Williams, and Valle Faults and possibly along the Patterson Pass Fuult.

There is no direct geologic evidence regarding location and recency of activity along other faults projected beneath the Valley floor. However, indirect evidence such as probable groundwater barriers and geophysical data suggests that several faults are present as subsurface features. Little evidence supports the existence of the Mocho Fault, and direct examination has ruled out the Doutherty and Corral Hollow Faults as features affecting nearsurface materials along their mapped projections. Indirect evidence for the existence of the Doutherty Fault at depth is very questionable. Trenching studies have failed to locate Strand 2 of the Tesla Fuult as projected toward LLNL by previous investigators. However, Quaternary movements may have occurred on portions of the Tesla Fault zone several miles southeast of LLNL-although direct field evidence for such movements is lacking.

Because of deep soil cover and landslide deposits in the area southeast of LLNL, the location of contacts between formations can only be inferred. The need to infer the location of contacts explains why there are many differences in the maps of this area. Further, since some faults are postulated on the juxtaposition of the formations, the existence 
of some fault traces is in doubt. Roads and stream channels are the best areas for examining deposits and locating contacts between formations. Recently excavated roadcuts and trenches have exposed bedrock profiles and locations that differ from those shown on previous maps.

Recent compilations by the USGS of regional seismicity show a close correspondence between centers of seismic activity and portions of the Calaveras and Greenville Fault zones. Additional diffuse seismicity, noted in an area located east of Del Valle reservoir and several kilometers south of LLNL, cannot be presently related to any particular fault. Rather, it may reflect movements on several relatively small faults that have been mapped in the area.

\section{PLANS FOR FURTHER STUDIES}

The first phase of the geologic investigation of the LLNL site and its environs has been completed. The principal purposes of this first phase of the study were to thoroughly review previous pertinent geological studies and to search LLNL and nearby areats for faults that displace late Quaternary materials. These objectives have been accomplished.

However, before a comprehensive geologic hazards appraisal of LLNL can be completed, additional studies are required. These studies have been planned and are listed in the following paragraphs.

\section{REGIONAL GEOLOGIC MAPPING}

- Studies of the Greenville-Carnegie Complex. Geologic evidence for a zone of young faults along the eastern margin of the Livermore Valley has been presented by the USGS and CDWR. Individual faults have been considered part of the Greenville or Carnegie Fuult zones, seemingly based on author preference. The January 1980 earthquake series is at least in part associated with these faults. The extent and geologic evidence for Quaternary activity along the fault complex needs to be critically evaluated. Further, the relationships of ihese faults to the Tesla Fault, Las Positas Fault, and faults on strike with the system in Contra Costa County need to be determined.

- Further Study of the Las Positas Fault Zone. Strong evidence for the existence of the Las Positas Fault zone is presently confined to the portion of the hillfront extending about $2 \mathrm{~km}$ northeast and southwest from SNLL. However, the USGS has mapped the fault over a much larger area. Air photo and field reconnaissance work is planned in order to assess the extent of the Las Positas Fault zone and its relationship to other regional faults such as the Greenville-Carnegie complex, the Livermore Fault, and possibly the Williams and Calaveras Faults.

- Evaluation of Area East of Del Valle Reservoir. A number of epicenters have been plotted in the area east of Del Valle reservoir and the CDWR has mapped the Williams and Valle Faults in this general area. A number of aftershocks of the January 1980 earthquake series occurred in this area and appear to relate to possible northeast trending faults mapped by Herd (1977). Airphoto studies and field reconnuissance are planned to provide a better understanding of observed seismicity.

- Evaluation of the Livermore Fault. The CDWR regards the Livermore Fault as a young, potentially active geologic structure; the USGS strongly disagrees. An independent assessment of the Livermore Fault is planned. Data obtained may also be important to the LLNL geohydrologic study since the CDWR regards the Livermore Fault as an important groundwater barrier.

Several months of field mapping at a scale of 1:24 000 and airphoto interpretation will be required in order to complete this work. Early operations of the seismic monitoring network may focus these studies, but an effort involving most of the Altamont 7-1/2 minute Quadrangles and portions of the Livermore, La Costa Valley, Mendenhall Springs, Midway, and Cedar Mountain Quadrangles is anticipated. 


\section{SUBSURFACE INVESTIGATIONS}

In cooperation with the planned geohydrology effort, samples will be obtained during the drilling of wells to monitor groundwater and from other boreholes. These samples should permit identification and correlation of strata beneath LLNL based on consistent criteria. It is presently not possible to determine the extent to which variations among existing test borings represent geologic changes and the extent to which they reflect variations in logging resulting from work by different geotechnical groups using differing technical standards.

In addition to the observation wells planned for the geohydrologic study, borings will be located to permit construction of one or two northeastsouthwest oriented cross sections. The planned observation wells and test borings will permit evaluation of deeper horizons and groundwater levels normal to the projected Tesla, Doutherty, and Corral Hollow Fault trends. About 31 holes roughly $30 \mathrm{~m}$ $(100 \mathrm{ft})$ in depth are planned. The locations of the planned exploratory holes and observation wells are shown on Fig. B-1 in Appendix B.

No further trenching studies are scheduled at this time. However, field mapping studies should identify locations where exploratory trenches will provide important data concerning fault locations, associations, and activity. Most of these locations will be on private property and, therefore, permission of owners will have to be obtained.

\section{AGE DATING}

The application of the ${ }^{230} \mathrm{Th} /{ }^{234} \mathrm{U}$ age dating method to caliche samples has already provided some significant results. Dating will continue and be supplemented by additional samples, if these can be collected at geologically significant locations. Attempts will be made to use caliche recovered from core samples for the dating of stratigruphic horizons at depth beneath LLNL.

Additional samples of carbonaceous materials suitable for dating by the ${ }^{14} \mathrm{C}$ method will be sought during field mapping studies and future exploratory programs. If suitable samples are found, additional ${ }^{14} \mathrm{C}$ dates will be obtained.

The feasibility of performing paleomagnetic studies on fine-grained sediments obtained from outcrops and future exploratory trenches is being investigated. This method of age dating will be applied if found pertinent.

Relative ages may be obtained by further examination of soil profile development in the LLNL area. This will be further explored as part of the planned Quaternary mapping study. 


\section{APPENDIX A \\ AIR PHOTO INTERPRETATION \\ by A. L. Ramirez and D. W. Carpenter}

Three sets of black and white air photographs were studied during the preliminary stages of the seismic safety assessment program. Photographs were examined and interpreted for features suggestive of faulting. The region examined included all of the area within the perimeter of the Laboratory as well as neighboring areas.

Photographs exannined were taken in 1940, 1958 and 1972, Two detailed monoscopic and stereoscopic analyses were made of each of the three photo sets. Each of the investigators worked independently of the others so that the results of one study would not influence the other's interpretations.

Tonal variations and linear patterns have been observed in photographs of areas within and adjacent to the LLNL sitc. Such tonal variations and linear patterns may indicate surface expressions of faults, or they may indicate other geologic [eatures such as former stream channels. These may also reflect cultural features unrelated to geology-such as buried pipes, Cormer fence lines, and farming patterns, Locations of all lineaments seen near LLNL are shown in Figs. 18 and 31.

The majority of the tonal variations and linear patterns observed can be described as faint or illdefined. However, well-defined linenments were also identified to the south and the southwest of the Laboratory, and coincide with the location of the Las Positas Fault as mapped by Herd (1977). Air photos taken in 1940, prior to the development of the LLNL site, do not snow any lineaments subparallel to the Las Positas zone within the area now occupied by the Laboratory. However, faint lineations crossing the southeast corner of the LLNL site can be seen on 1958 and 1972 air photos. These faint lineations strike subparallel to the Las Positas Fault of Herd (1977).

The 1940 aerial photographs show a stream channel in the area where faint lineaments and id? variutions, attributed to the Doutherty Fault (Blume, 1972), can be seen on later photographs. Discontinuous lineaments and faint tone patterns were observed in the area where Strands I and 2 of the Tesla Fault zone have been projected (Blume, 1972).

Faint and discontinuous tonal variations that cut across the entire LLNL site were observed by one investigator. The southeastern segment of these tonal variations is indistinct in places but roughly coincides with the projected position of the Corral Hollow Fault trace (Blume, 1971). The northwestern segment diverges to the west of the projected fault trace and is probably part of a surface drainage channel. A short discontinuous and faint lineament was observed to intersect the northeastern corner of the Laboratory's perimeter and will be evaluated further during regional geologic studies. 


\title{
APPENDIX B \\ ANALYSIS OF EXISTING SUBSURFACE DATA
}

\author{
by A. L. Ramirez and D. W. Carpenter
}

As part of the preliminary investigations for the seismic safety assessment program, copies of the geotechnical investigation reports for foundation designs of many of the buildings in the Laboratory were compiled and examined. This information is in the files of the LLNL Plant Engineering Department. Table B-1 summarizes important characteristics of all known exploratory borings that were drilled during the foundation investigations. Figure B-1 shows the locations of these borings.

A total of 132 test borings are known to have been drilled during the foundation investigations. Many borings are shallow (10-30 ft in depth), but some extend to depths of as much as $126 \mathrm{ft}$. Drillers' logs of two water wells and five cathodic protection wells also exist. The two water wells were located along the western boundary of LLNL and were drilled to a depth of $702 \mathrm{ft}$ each. The cathodic protection wells average about $300 \mathrm{ft}$ in depth.

Logs of all known borings were examined and some rough plots were made to aid planning of future site geologic studies. Data from existing test borings and from future LLNL exploratory drilling will be used in the preparation of the final geologic report.

Logs of test borings on the LLNL site were prepared by the consultants' personnel at various times and in accordance with a variety of logging standards, thereby complicating analysis and interpretation. However, most holes drilled during the past 10 to 15 years appear to have been logged in accordance with the Unified Soils Classification system, a generally accepted standard in geotechnical professions.

Accuracy of the test boring logs cannot be independently judged; none of the borings are known to have been observed by LLNL geoscience personnel, In general, it may be assumed that the most accurate logs are of borings in which frequent soil samples were obtained or that were drilled with a bucket auger, a rig that returns all materials to the surface for inspection. Logs of holes drilled by wash boring techniques or of deep borings drilled by screw-type augers must be regarded as of limited value in establishing subsurface conditions, unless frequent soil samples were recovered.

No geophysical logs, which could have been of assistance in establishing lithologies between sampling points, have been found. It is doubtful that any exist since geophysical logs are not usually obtained during foundation studies for buildings.

Groundwater at a depth of $74 \mathrm{ft}$ was reported in test boring 391-1, drilled at the site of additions to Bldg. 39l. Groundwater was not reported as having been encountered in other test borings at LLNL except for a shallow seep observed in boring 435- 1 . Notes on logs of many test borings indicate that groundwater was either not encountered or that where water was added during drilling (wash borings) the water levels were declining at the completion of drilling.

No test borings are known to have been completed to permit long-term groundwater level observations,

TABLE B-1. Summary of test boring data.

\begin{tabular}{llcccccc}
\hline Bidg. & Hole \# & $\begin{array}{c}\text { Elevation } \\
\text { it }\end{array}$ & $\begin{array}{c}\text { Depth } \\
\text { it }\end{array}$ & Method & Date & Consultant & Remarks \\
\hline I11 & $111-1$ & 617 & 80 & bucket auger & Mar/1966 & Dames \& Moore & \\
& $111-2$ & 617 & 67 & & & & \\
$111-3$ & 616 & 57 & & & & \\
$111-4$ & 620 & 60 & & & \\
& $111-5$ & 617 & 58 & & &
\end{tabular}


TABLE B-1. (Continued.)

\begin{tabular}{|c|c|c|c|c|c|c|c|}
\hline Bldg. & Hole $\#$ & $\begin{array}{c}\text { Elevation } \\
\mathrm{ft}\end{array}$ & $\begin{array}{l}\text { Depth } \\
\text { it }\end{array}$ & Method & Date & Consultant & Remarks \\
\hline \multirow[t]{10}{*}{113} & $113-1$ & 624.7 & 40 & \multirow[t]{10}{*}{$\mathbf{N} / \mathbf{A}$} & \multirow[t]{10}{*}{$\mathbf{N} / \mathbf{A}$} & \\
\hline & $113-2$ & 624.5 & 40 & & & \multirow{9}{*}{ Dames \& Moore } & \\
\hline & $113-3$ & 624.5 & 40 & & & & \\
\hline & $113-4$ & 622.9 & 40 & & & & \\
\hline & 113.5 & 623.5 & 40 & & & & \\
\hline & $113-6$ & 621,2 & 40 & & & & \\
\hline & $113-7$ & 621.7 & 20 & & & & \\
\hline & $113-8$ & 6211.8 & 20 & & & & \\
\hline & $11,3-9$ & 620.3 & 65 & & & & \\
\hline & $11.3-11$ & 62.3 .3 & 65 & & & & \\
\hline \multirow[t]{4}{*}{121} & $121-1$ & 616.5 & 25.5 & \multirow[t]{4}{*}{ hucket auger } & \multirow[t]{4}{*}{ Mlay/1956 } & \multirow[t]{4}{*}{ Dames \& Moore } & \\
\hline & 121.2 & 617.3 & 16.5 & & & & \\
\hline & $|2|+3]$ & 617,6 & 21,5 & & & & \\
\hline & $121-4$ & 618.2 & 25.11 & & & & \\
\hline \multirow[t]{5}{*}{1.31} & $1.31-1$ & 6118.7 7 & 32.5 & \multirow[t]{5}{*}{ hueket auger } & \multirow[t]{5}{*}{ Sept/1957 } & \multirow[t]{5}{*}{ James \& Moore } & \\
\hline & 1.31 .2 & 611.3 & 27.5 & & & & \\
\hline & 131.3 & 610.5 & 21.5 & & & & \\
\hline & $131-4$ & 611.1 & 24.11 & & & & \\
\hline & $131-5$ & 612.6 & 26.5 & & & & \\
\hline \multirow[t]{5}{*}{131} & $131-1 A$ & 606.7 & 34.5 & \multirow[t]{5}{*}{ bueket auger } & \multirow[t]{5}{*}{$\operatorname{Jan} / 1963$} & \multirow[t]{5}{*}{ Dames \& Moore } & $\begin{array}{l}\text { Borings drilled for additions to the } \\
\text { building. }\end{array}$ \\
\hline & $|3|-2 A$ & 611,0 & .31 .0 & & & & \\
\hline & $131-3 A$ & 6019.7 & 35.5 & & & & \\
\hline & $131-4 A$ & 6111.5 & 30.5 & & & & \\
\hline & $131-5 A$ & 613.2 & 36.0 & & & & \\
\hline 166 & $166-1$ & 595.3 & 20 & hucket auger & Sept $/ 1961$ & Dames \& Moore & $\begin{array}{l}\text { Hole previously referred to as hole } \# 3 \text { of } \\
\text { Bldg. 166; data included in report for } \\
\text { Bldg. 261. }\end{array}$ \\
\hline \multirow[t]{2}{*}{239} & $239-1$ & 618.3 & 60 & \multirow[t]{2}{*}{ hucket auger } & \multirow[t]{2}{*}{ June/ 1967} & \multirow{2}{*}{$\begin{array}{l}\text { Cooper-Clark } \\
\text { \& Assoc. }\end{array}$} & \\
\hline & $239-2$ & 615,3 & 58 & & & & \\
\hline \multirow[t]{3}{*}{241} & $241-1$ & 609.2 & 25 & \multirow[t]{3}{*}{$N / A$} & \multirow[t]{3}{*}{ July/1958 } & Woodward, Clyde, & Borings map shaws a building shaped \\
\hline & $241-2$ & 610.8 & 15 & & & & \\
\hline & $241-3$ & 608.8 & 20 & & & & \\
\hline 251 & $251-1$ & 603,2 & 40 & rotery wash & Oct / 1966 & Harding Miller & \\
\hline & $251-2$ & 603.1 & 50 & and auger & & I.awson \& Assoc. & \\
\hline & $251-3$ & 603.4 & 46 & & & & \\
\hline & $251-4$ & 603.2 & 80 & & & & \\
\hline & 251-5 & 603.3 & 4 & & & & \\
\hline & $251-6$ & 603.3 & 4 & & & & \\
\hline 253 & 253-1 & 600 & 25 & screw-type & Mar/1964 & Rohert S. Cooper & \\
\hline & $253-2$ & 602 & 28 & auger & & \& Assoc. & \\
\hline & $253-3$ & 602 & 25 & & & & \\
\hline 261 & $261-1$ & 597 & 30 & power auger & Feb/1958 & Woodward, Clyde, & \\
\hline & $261-2$ & 596 & 25 & & & Sherard \& Assoc. & \\
\hline
\end{tabular}


TABLE B-1. (Continued.)

\begin{tabular}{|c|c|c|c|c|c|c|c|}
\hline Bldg. & Hole \# & $\begin{array}{c}\text { Elevation } \\
\text { ff }\end{array}$ & $\begin{array}{c}\text { Depth } \\
\text { ft }\end{array}$ & Method & Date & Consultant & Remarks \\
\hline 261 & $\begin{array}{l}261-1 A \\
261-2 A\end{array}$ & $\begin{array}{l}594.8 \\
595.7\end{array}$ & $\begin{array}{l}20 \\
20\end{array}$ & bucket auger & Sept/1961 & Dames \& Mloure & $\begin{array}{l}\text { Locatian of these borings abtained from } \\
\text { LRL Test Borings Plans, by process of } \\
\text { elimination. }\end{array}$ \\
\hline 261 & $\begin{array}{l}261-1 B \\
261-2 B \\
261.38 \\
261.41\end{array}$ & $\begin{array}{l}595.7 \\
596.0 \\
597.1 \\
597.4\end{array}$ & $\begin{array}{l}21 \\
21 \\
21 \\
21\end{array}$ & $\begin{array}{l}\text { continuous } \\
\text { flight }\end{array}$ & Dec/1970 & $\begin{array}{l}\text { Woodward-Clyde } \\
\mathbb{R} \text { Assoc. }\end{array}$ & Borings drilled for building additions. \\
\hline $\begin{array}{l}\text { Pipe- } \\
\text { line }\end{array}$ & $\begin{array}{l}\text { P-2 } \\
\text { P-2 }\end{array}$ & $\begin{array}{l}589.5 \\
591.5\end{array}$ & $\begin{array}{l}31.5 \\
32.1\end{array}$ & $\begin{array}{l}\text { continuous } \\
\text { night }\end{array}$ & May/1973 & $\begin{array}{l}\text { Woudward-Lundgre } \\
\text { \& Assoc. }\end{array}$ & \\
\hline 291 & $\begin{array}{l}291-1 \\
291-2\end{array}$ & $\begin{array}{l}587.5 \\
587\end{array}$ & $\begin{array}{l}31.5 \\
16\end{array}$ & auger & Apr/ 1970 & $\begin{array}{l}\text { Woudward-l.undgre } \\
\& \Lambda \text { ssoc. }\end{array}$ & \\
\hline 311 & $\begin{array}{l}3 \mid 1-1 \\
311-2\end{array}$ & $\begin{array}{l}628.7 \\
6,32\end{array}$ & $\begin{array}{l}38 \\
41\end{array}$ & bucket auger & July / 1964 & Dames $\&$ Nnure & \\
\hline 321 & $\begin{array}{l}321-1 \\
321-2 \\
321-3 \\
321-4\end{array}$ & $\begin{array}{l}622.6 \\
62.3 .1 \\
624.7 \\
625.2\end{array}$ & $\begin{array}{l}19.5 \\
3.3 .0 \\
19.5 \\
29.0\end{array}$ & bucket auger & Feb/1958 & Dames \& Maore & \\
\hline .327 & $327-1$ & 621 & 40 & power auger & Feh/1958 & $\begin{array}{l}\text { Woodward, Clyde, } \\
\text { Sherard \& Assoc. }\end{array}$ & $\begin{array}{l}\text { Titie of report indicates that this hole } \\
\text { was drilled for Bldg. 321; however, } \\
\text { coordinate positions suggest it was } \\
\text { drilled for Bldg. 327, and was included } \\
\text { in report for Bldg. 261. }\end{array}$ \\
\hline 332 & $\begin{array}{l}332-1 \\
332-2 \\
332-3 \\
332-4 \\
332-5 \\
332-6\end{array}$ & $\begin{array}{l}N / A \\
620,0 \\
616.0 \\
619.0 \\
615.5 \\
615.5\end{array}$ & $\begin{array}{l}31 \\
31 \\
31 \\
31 \\
31 \\
31\end{array}$ & bucket auger & Feh/1958 & $\begin{array}{l}\text { Soil Testing } \\
\text { Services }\end{array}$ & \\
\hline 332 & $\begin{array}{l}332-1 A \\
332-2 A \\
332-3 A \\
332-4 A \\
332-5 A \\
332-6 A\end{array}$ & $\begin{array}{l}617.4 \\
N / A \\
617.5 \\
620.3 \\
617.3 \\
616.9\end{array}$ & $\begin{array}{l}100 \\
50 \\
80 \\
51.5 \\
51.5 \\
49.5\end{array}$ & bucket auger & Oct / 1972 & $\begin{array}{l}\text { Shannon \& } \\
\text { Wilson }\end{array}$ & $\begin{array}{l}\text { Holes drilled in support of exploration } \\
\text { for additions to bldg. 332; a trench was } \\
\text { also excavated for this investigation } \\
\text { (for location see Fig. B-1). }\end{array}$ \\
\hline 341 & $\begin{array}{l}341-1 \\
341-2 \\
341-3\end{array}$ & $\begin{array}{l}613.8 \\
614.8 \\
614.5\end{array}$ & $\begin{array}{l}18.5 \\
24,0 \\
23.0\end{array}$ & & Oct $/ 1962$ & $\begin{array}{l}\text { Woodward, Clyde, } \\
\text { Sherard \& Assoc. }\end{array}$ & \\
\hline 361 & $\begin{array}{l}361-1 \\
361-2 \\
361-3 \\
361-4 \\
361-5 \\
361-6\end{array}$ & $\begin{array}{l}604,0 \\
606,0 \\
603,0 \\
603,0 \\
602,5 \\
603,5\end{array}$ & $\begin{array}{l}25 \\
25 \\
25 \\
25 \\
25 \\
25\end{array}$ & bucket guger & Nov/ 1965 & $\begin{array}{l}\text { Robert S. } \\
\text { Cooper A Assoc. }\end{array}$ & $\begin{array}{l}\text { Holes } 361-5,361-6 \text { are referred to } \\
\text { respectively as holes } 9 \& 10 \text { in the soils } \\
\text { report. }\end{array}$ \\
\hline
\end{tabular}


TARLE B-1. (Continued.)

\begin{tabular}{|c|c|c|c|c|c|c|c|}
\hline Bidg. & Hole \# & $\begin{array}{l}\text { Elevation } \\
\mathbf{f}\end{array}$ & $\begin{array}{l}\text { Depth } \\
\text { II }\end{array}$ & Method & Date & Consultant & Remarks \\
\hline \multirow[t]{4}{*}{364} & $364-1$ & 600.0 & 25 & \multirow[t]{4}{*}{ bucket auger } & \multirow[t]{4}{*}{ Now/1965 } & \multirow{4}{*}{$\begin{array}{l}\text { Robert S. } \\
\text { Cooper \& Assoc. }\end{array}$} & \multirow{4}{*}{$\begin{array}{l}\text { Holes } 364-1,2,3,4 \text {, are referred to } a 5 \\
\text { holes } 5,6,7,8 \text { in the solls report. }\end{array}$} \\
\hline & $364-2$ & 601.0 & 25 & & & & \\
\hline & $364-3$ & 600.5 & 25 & & & & \\
\hline & $364-4$ & 600.5 & 25 & & & & \\
\hline \multirow[t]{4}{*}{391} & $391-1$ & 593.0 & 126 & \multirow[t]{4}{*}{ rotary wash } & \multirow[t]{4}{*}{ Mar/1978 } & \multirow[t]{4}{*}{ Dames Moore } & \multirow{4}{*}{$\begin{array}{l}\text { Stabilized water level at } 74 \text { it in } \\
\text { boring 391-1. }\end{array}$} \\
\hline & 391.2 & 593.11 & 50 & & & & \\
\hline & $341-3$ & 594.0 & so & & & & \\
\hline & $391-4$ & 595.0 & 52 & & & & \\
\hline \multirow[t]{2}{*}{4,31} & $4.31=1$ & 619.7 & 124.5 & \multirow{6}{*}{$\begin{array}{l}\text { bucket auger } \\
\text { \& cable tool }\end{array}$} & \multirow[t]{2}{*}{ June/ 1950} & \multirow[t]{2}{*}{ Dames \& Moore } & \multirow{2}{*}{$\begin{array}{l}\text { Cable tool used on } 431-2 \text { from } 65 \text { if to } \\
125.5 \text { depth. }\end{array}$} \\
\hline & 431.2 & 621,7 & 125.5 & & & & \\
\hline \multirow[t]{4}{*}{4.31} & $. .31-1 A$ & 622.2 & 48.5 & & \multirow[t]{4}{*}{ Mar/1964 } & \multirow{4}{*}{$\begin{array}{l}\text { Woodward, Clyde, } \\
\text { Sherard \& Assoc. }\end{array}$} & Holes were drilled in support of ex- \\
\hline & $431-2 A$ & 62.3 .7 & 53.5 & & & & $\begin{array}{l}\text { ploration for Astron Tunnel (addition to } \\
\text { Bldg, 431). }\end{array}$ \\
\hline & $\mathbf{4 3 1 - 3 A}$ & 624.5 & 46.0 & & & & \\
\hline & $431-4 A$ & 626.1 & 51.5 & & & & \\
\hline \multirow[t]{2}{*}{4.11} & $431-1 \mathrm{~B}$ & $N / A$ & 86 & continuous & \multirow[t]{2}{*}{ Dec/1977 } & \multirow[t]{2}{*}{ Bechtel, Inc. } & \multirow{2}{*}{$\begin{array}{l}\text { Borings done in support of MFTF con- } \\
\text { version. }\end{array}$} \\
\hline & $431-2 B$ & $N / A$ & 82 & Night auger & & & \\
\hline \multirow[t]{5}{*}{4.35} & $436-1$ & 6211.5 & 30 & \multirow[t]{5}{*}{ power nuger } & \multirow[t]{5}{*}{ May/1958 } & Woodward, Clyde, & Hole 435-I encountered free water at \\
\hline & $435-2$ & 622.2 & 25 & & & & \\
\hline & $435-3$ & 621.1 & 30 & & & & \\
\hline & $435-4$ & 619.7 & 29 & & & & \\
\hline & $435-5$ & 621.1 & 27.5 & & & & \\
\hline 441 & $441-1$ & 623 & 29.0 & auger & Aug / 1978 & Woodward-Clyde & Holes $441-1,2,3,4,5,6$ are referred to \\
\hline & $441-2$ & 624.5 & 19.5 & & & Consultants & $\begin{array}{l}\text { in the soils report. } \\
\text { ing }\end{array}$ \\
\hline & $441-3$ & 625 & 20.1 & & & & \\
\hline & $441-4$ & 626 & 39 & & & & \\
\hline & $44:: 5$ & 626 & 20 & & & & \\
\hline & $441-6$ & 624.5 & 16.5 & & & & \\
\hline 451 & $451-1$ & 613 & 24.5 & muger & Aug/1977 & Woodward-Clyde & \\
\hline & $\mathbf{4 5 1 - 2}$ & 614 & 21.5 & & & Consultants & \\
\hline & $451-3$ & 614 & 23.5 & & & & \\
\hline & $451-4$ & 613 & 41.0 & & & & \\
\hline & $45 I-5$ & 612 & 24.5 & & & & \\
\hline & $451-6$ & 612 & 24.5 & & & & \\
\hline & $451-7$ & 613 & 16.5 & & & & \\
\hline 481 & $481-1$ & 595.5 & 41 & rotary wash & Apr / 1979 & Dames \& Moore & Holes are referred to respectively as \\
\hline & $491-2$ & 600 & 41 & & & & L. F. G in ine solls report. \\
\hline & $481-3$ & 600 & 41 & & & & \\
\hline $5 I 1$ & $511-1$ & 642.5 & 20 & screw-type & Mar/1964 & Robert S. & Holes 511-1 and 511-2 are referred to \\
\hline & $511-2$ & 639.8 & 20 & auger & & Cooper \& Assoc. & $\begin{array}{l}\text { as holes } 4 \& 5 \text { in the soils report. They } \\
\text { were drilled for an addition to the struc- } \\
\text { ture as part of the same exploratory } \\
\text { program as Bldg. } 253 \text {. }\end{array}$ \\
\hline
\end{tabular}


TABLE B-1. (Continued.)

\begin{tabular}{|c|c|c|c|c|c|c|c|}
\hline Bldg: & Hole : & $\begin{array}{c}\text { Elevation } \\
\text { fi }\end{array}$ & Depth & Method & Date: & Conssultant & Remarks \\
\hline \multirow[t]{6}{*}{551} & $551-1$ & 614.5 & 29 & continuous & Aug/1978 & Woodward-Clyde & \\
\hline & $551-2$ & 616.5 & 14.5 & Night wuger & & Consultants & \\
\hline & $551-3$ & 618.5 & 19 & & & & \\
\hline & $551-4$ & 619,5 & 39 & & & & \\
\hline & $551-5$ & 618 & 29 & & & & \\
\hline & $551-6$ & 616 & 19.5 & & & & \\
\hline \multicolumn{8}{|c|}{ Substation } \\
\hline $230 /$ & ss-1 & 631,3 & 20 & continuous & Jan/1979 & Peter Kaldveer & \\
\hline 13.8 & SS-2 & 631.0 & 20 & night auger & & & \\
\hline KV & SS-3 & 630.5 & 20 & & & & \\
\hline
\end{tabular}

$\mathbf{N} / \mathbf{A}=$ not available. 


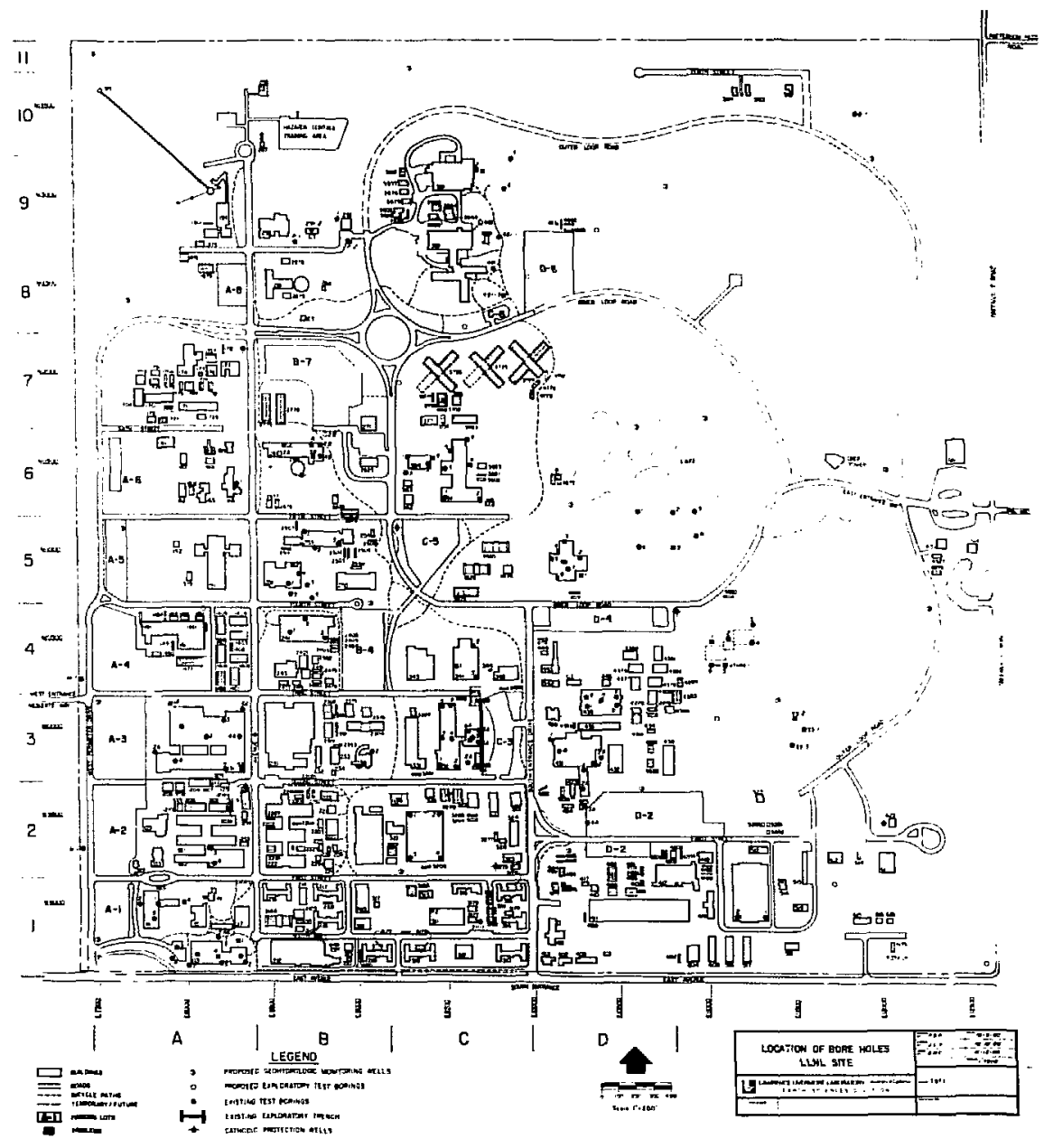

FIG. B-1. Map of borehole locations at LLNL. 


\section{APPENDIX C \\ URANIUM-SERIES DATING OF PEDOGENIC CARBONATES \\ FROM THE-LIVERMORE-VALLEY \\ by Kevin Knauss}

\section{INTRODUCTION}

As part of the Site Investigation being undertaken by DOE at LLNL and SNLL, seven exploratory trenches, two storm sewer trenches, an outcrop, a roadcut, and a basement excavation have been mapped. Within these exposures a variety of pedogenic carbonates were encountered, including finely disseminated caliche from near surface sandy layers, caliche filled desiccation cracks (in some cases up to $1 / 2$ in. thick) at the base of argillic "B" soil horizons within buried paleosols, root casts, massive nodular caliche presumably from the Plio-Pleistocene Livermore gravels, and caliche cements from clayey gouge zones along faults. Age dates for these materials may provide a time stratigraphy for the alluvial units mapped, and hence may provide some limits (minimum age) for last-fault movement and establish the degrce of tectonic s:ability.

Recently, a technique was developed to age date pedogenic carbonates in gravelly desert soils (Ku et al., 1979) using uranium-series methods. The results presented in this appendix are an attempt to extend the uranium series method to the dating of semi-arid region pedogenic carbona:es from the Livermore Valley. The nine samples from the Livermore Valley studied thus far include six specimens taken from argillic " $B$ " horizons. The "B" horizon within a paleosol is generally thought of as a zone of accunulation or illuviation, and in alkaline environments the "B" horizon has been considered a "chemically closed system" (Hunt. 1972). However, during pluvial periods within the Pleistocene this concept of the " $B$ " horizon may not have been correct. The age dating implications of an "open system" will be discussed later. In addition, one of three wood fragment samples collected from the trenches contained enough material to be age dated by the ${ }^{1+} \mathrm{C}$ method. A brief description of the samples is provided in Table C-1.

TABLE C-1. Descriptions of samples.

List A: Samples giving reliable age dates

E-1 C1a

E-1 C2a

Greenville Rd. \#1

Greenville Rd. \#2

E-5 \#1

E-5 43
Carbonate samples

Caliche filling vertical shrinkage fractures up to 8 in. long and $1 / 2$ in. thick. Taken from argillic $B$ horizon in soil profile (unit 9) approx 11 ft below present surface at Sta. $1+67$.

Caliche taken in position stratigraphically equivalent to E-I Cla at Sta. $1+72$.

Grey-white mudstone (unit 9) containing abundant disseminated caliche. Unit associated with Las Positas. Fault zone and present only south of the zone.

Sample taken on revisit to Greenville Rd. cut; equivalent to Greenville Rd. $\nRightarrow I$.

Caliche filling vertical shrinkage fractures in clayey members of unit 5 approx $10 \mathrm{ft}$ below present surface at $S t a .2+34$.

Caliche filling vertical fractures in silty clay (unit 5 ) approx 10 ft below present surfuce at Sta. I+40 on west wall of trench.

Wood samples 
TABLE C-1. (Continued.)

List B: Samples giving unreliable age dates

\section{E-2 \#2}

E-6 \#1

Bidg 391
Caliche filling vertical fractures in silty clay (unit 3a) approx $5-1 / 2$ ft below present surface at Sta. $2+15$.

Composite sample taken from caliche filling vertical fractures in silty clay (unit 2) approx 5 ft below present surface between Sta. 0-5 and 0-15.

Traces of caliche filling narrow fractures coated with reddish brown clay in large lens of sandy silt (unit 3) approx 8 ft below present surface at Sta. $1+56$.

\section{AGE CALCULATIONS}

The caliche samples were analyzed using a modification of the procedure of Ku and Joshi (1980) and $\mathrm{Ku}$ et al, (1979). The procedure includes a weak acid leaching of the carbonate followed by isotopic analyses of both the leachate and residue. As a first approximation, the leach analytical data can be used to represent data for the carbonate, Ages of the samples as calculated from leach data are listed in Table C-2 as Age'. These ages should be amenable to refinement, as shown below.

An upper limit may be estimated for the age of the carbonate using the assumption that the carbonate phase was initially free of ${ }^{230} \mathrm{Th}$ ( $\mathrm{Ku}$ and Joshi, 1980). Calculated ages using this correction scheme are listed as $\mathrm{Age}^{2}$ in Table C-2. Alternatively, one may make assumptions abou the nature of the detrital phase and calculate a slightly different corrected age ( $\mathrm{Ku}$ et al, 1979). These corrected ages are listed as $\mathrm{Age}^{3}$ in Table C-2. For a derivation of the model age equations, see the references mentioned above. Table C-2 contains the analytical data and modeled data for the nine caliche samples analyzed. The term $F_{L}$ refers to the leach fraction, i.e., that fraction of the sample that was soluble in dilute acid. Figure $\mathrm{C}-1$ presents the ages in a graphical format. The best estimate is taken as the mean of $\mathrm{Agel}^{\mathrm{l}}$ and $\mathrm{Age}^{3}$. These best estimates for the age dates that are considered reliable are summarized in Table C-3.

The wood fragment from Trench E-3 was dated by Dr. Steve Robinson of the USGS, Menlo Park. Standard ${ }^{14} \mathrm{C}$ dating techniques and age calculations were employed. The fragment's age is also presented in Table C-3.

TABLE C-2. Sample data.

\begin{tabular}{|c|c|c|c|c|c|c|c|c|c|c|c|c|}
\hline \multirow[b]{2}{*}{ Sample } & \multicolumn{5}{|c|}{ Analytical Data } & \multicolumn{2}{|c|}{ Concentraìion } & \multicolumn{3}{|c|}{ Activity Ratio } & \multirow[b]{2}{*}{$\mathbf{F}_{\mathbf{L}}$} & \multirow[b]{2}{*}{$\frac{\text { Dating Resul }}{\left(\times 10^{3} \mathrm{yr}\right)}$} \\
\hline & & ${ }^{232} \mathrm{Th}$ & ${ }_{(d p n}$ & $\begin{array}{l}234 U \\
m / g)\end{array}$ & $\overline{2^{230}}$ & $\mathbf{U}$ & m) & $\begin{array}{l}\overline{234_{U /}} \\
238_{U}\end{array}$ & $\begin{array}{l}{ }^{230} 0_{\mathrm{Th}} / \\
{ }^{232} \mathrm{Th}\end{array}$ & $\begin{array}{l}230_{\mathrm{Th} /} \\
234_{\mathrm{U}}\end{array}$ & & \\
\hline \multirow[t]{6}{*}{ E-I Cla } & Leach & 0.236 & 1.343 & 1.486 & 0.879 & 1.799 & 0.974 & 1.107 & 3.717 & 0.591 & 0.712 & $\mathrm{Age}^{1}=100$ \\
\hline & & \pm 0.011 & $\pm 0,032$ & \pm 0.034 & \pm 0.024 & \pm 0.042 & \pm 0.046 & \pm 0.030 & \pm 0.189 & \pm 0.021 & & \\
\hline & Residue & 1.054 & 1.343 & 1.212 & 1.814 & 1.799 & 4.347 & 0.903 & 1.720 & 1.496 & & \\
\hline & & $\pm 0,042$ & $\pm 0,031$ & \pm 0.029 & \pm 0.057 & \pm 0.041 & \pm 0.172 & \pm 0.028 & $\pm 0,078$ & $\pm 0,059$ & & \\
\hline & Carbonate & N/A & 1,343 & 1,433 & 1.070 & $\mathbf{N} / \mathbf{A}$ & N/A & 1.067 & $\mathbf{N} / \mathbf{A}$ & 0.747 & N/A & $\mathrm{Age}^{2}=145$ \\
\hline & Carbonate & $\mathbf{N} / \mathbf{A}$ & 0.746 & 0.836 & 0,473 & $\mathbf{N} / \mathbf{A}$ & N/A & 1,121 & $\mathbf{N} / \mathbf{A}$ & 0.566 & $\mathbf{N} / \mathbf{A}$ & $\mathrm{Age}^{3}=95$ \\
\hline \multirow[t]{2}{*}{ E-1 C2a } & Leach & 0.168 & 1.745 & 1.961 & 1.385 & 2.338 & 0.695 & 1.124 & 8,210 & 0.706 & 0.663 & Age $^{1}=135$ \\
\hline & & $\pm 0,006$ & \pm 0.045 & $\pm 0,049$ & $\pm 0,020$ & \pm 0.060 & \pm 0.024 & \pm 0.031 & \pm 0.298 & \pm 0.021 & & \\
\hline
\end{tabular}


TABLE C-2. (Continued.)

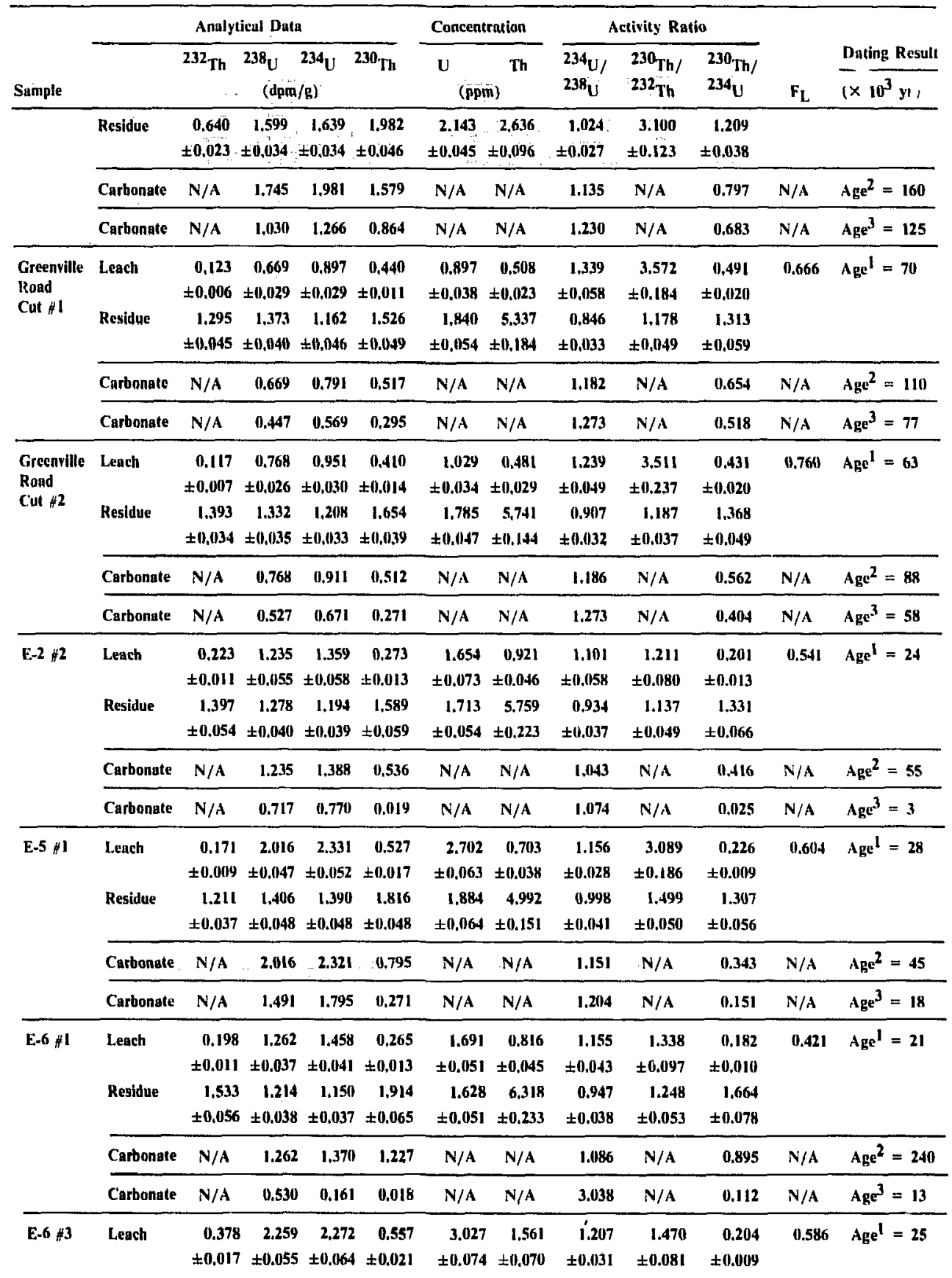


TABLE C-2. (Continued.)

\begin{tabular}{|c|c|c|c|c|c|c|c|c|c|c|c|c|}
\hline \multirow{5}{*}{ Sample } & \multicolumn{5}{|c|}{ Analytical Data } & \multicolumn{2}{|c|}{ Concentration } & \multicolumn{3}{|c|}{ Activity Ratio } & \multirow{5}{*}{$\mathbf{F}_{\mathbf{L}}$} & \multirow{3}{*}{$\frac{\text { Dating Result }}{\left(\times 10^{3} \mathrm{yr}\right)}$} \\
\hline & \multirow{4}{*}{ Residue } & ${ }^{232} \mathrm{Th}$ & ${ }^{238_{\mathrm{U}}}$ & $234_{\mathrm{U}}$ & ${ }^{230} \mathrm{Th}$ & U & $\mathbf{T h}$ & \multirow{4}{*}{$\begin{array}{r}234 U / \\
238 U \\
0.971 \\
\pm 0.033\end{array}$} & \multirow{4}{*}{$\begin{array}{r}{ }^{230} \mathrm{Th} / \\
232 \mathrm{Th} \\
1.179 \\
\pm 0.054\end{array}$} & \multirow{4}{*}{$\begin{array}{r}{ }^{230_{\mathrm{Th}} /} \\
234_{\mathrm{U}} \\
1,689 \\
\pm 0,084\end{array}$} & & \\
\hline & & & (dpm & & & (ppm & & & & & & \\
\hline & & 1.899 & 1,364 & 1.325 & 2.239 & 1.829 & 7.825 & & & & & \\
\hline & & \pm 0.082 & \pm 0.037 & \pm 0.037 & \pm 0.092 & \pm 0.050 & \pm 0.339 & & & & & \\
\hline & Carbonate & $\mathbf{N} / \mathbf{A}$ & 2.259 & 2.700 & I.174 & $\mathbf{N} / \mathbf{A}$ & N/A & 1.194 & $\mathbf{N} / \mathbf{A}$ & 0.434 & $\mathbf{N} / \mathbf{A}$ & $\mathrm{Age}^{2}=59$ \\
\hline & Carbonate & $\mathbf{N} / \mathbf{A}$ & 1.196 & 1.636 & 0,113 & $\mathbf{N} / \mathbf{A}$ & $\mathbf{N} / \mathbf{A}$ & 1.368 & $\mathbf{N} / \mathbf{A}$ & 0,068 & $\mathbf{N} / \mathbf{A}$ & $\mathrm{Age}^{3}=9$ \\
\hline \multirow[t]{6}{*}{ Pldg. 391} & L.each & 0,541 & 1.359 & 1,510 & 0,592 & 1,821 & 2,225 & 1,111 & 1,097 & 0,392 & 0,286 & $A \mathrm{AE}^{1}=53$ \\
\hline & & $\pm 0,0124$ & $\pm 0,045$ & $\pm 0,048$ & $\pm 0,026$ & $\pm 0,059$ & $\pm 0,101$ & $\pm 0,045$ & $\pm 0,066$ & $\pm 0,021$ & & \\
\hline & Residue & 1.681 & 1.479 & 1.409 & 1.607 & 1.982 & 6,929 & 0.953 & 0.956 & 1.140 & & \\
\hline & & $\pm 10,072$ & \pm 0.031 & \pm 0.029 & \pm 0.071 & \pm 0.041 & \pm 0.296 & \pm 0.023 & \pm 0.041 & \pm 0.056 & & \\
\hline & Carbonate & $\mathbf{N} / \mathbf{A}$ & 1.359 & 1.335 & 0.911 & N/A & $\mathbf{N} / \mathbf{A}$ & $0.983^{b}$ & N/A & 0.682 & $\mathbf{N} / \mathbf{A}$ & $\mathrm{Age}^{2}=120$ \\
\hline & Carbonate & $\mathbf{N} / \mathbf{A}$ & 0.523 & 0.500 & 0.076 & $N / A$ & N/A & $0.955^{b}$ & N/A & 0,152 & N/A & $\mathrm{Age}^{3}=19$ \\
\hline
\end{tabular}

${ }^{a} \mathrm{~N} / \mathbf{A}=$ Not applicable to dating method.

h. The corrected carbonate ${ }^{234} \mathrm{U} /{ }^{23 \mathrm{~B}} \mathrm{U}$ must he assumed approximately 1.0 to even attempt to calculate model ages.

TABLE C-3. Best estimates of age of samples that were dated.

\begin{tabular}{llc}
\hline Sample & Type & $\begin{array}{c}\text { Best estimate of } \\
\text { age }\left(\times 10^{3} \mathbf{y}\right)\end{array}$ \\
\hline E-1 Cla & carbonate & 98 \\
E-1 C2a & carbonate & 132 \\
Greenville Rd. $\# 1$ & carbonate & 73 \\
Greenville Rd. $\# 2$ & carbonate & 60 \\
E-3 & wood & 17 \\
E-5 $\# 1$ & carbonate & 23 \\
E-6 $\# 3$ & carbonate & 17 \\
\hline
\end{tabular}

\section{DISCUSSION OF AGE DATE RELIABILITY}

Most of the samples dated thus far consist of relatively thick caliche filled desiccation cracks in argillized " $B$ " soil horizons. These samples are in contrast to the relatively massive, impermeable pebble coatings dated by $\mathrm{Ku}$ et al. (1979), although they are similar to the carbonate cementations of an arid-zone fanglomerate deposit dated by $\mathrm{Ku}$ and Joshi (1980). There are intuitive concerns dealing with the "closed system" nature of the Livermore Valley pedogenic carbonates. Although the "B" soil horizon is generally considered to be a zone of accumulation in alkaline environments, conceivably during wetter periods it may have been subject to leaching and material transport. Directly confirmation of the "closed system" nature of these pedogenic carbonates would require concordia between these ${ }^{230} \mathrm{Th} /{ }^{234} \mathrm{U}$ dates and ages obtained from other radiometric dating methods. Such methods are not available in this instance; therefore, evaluations will have 


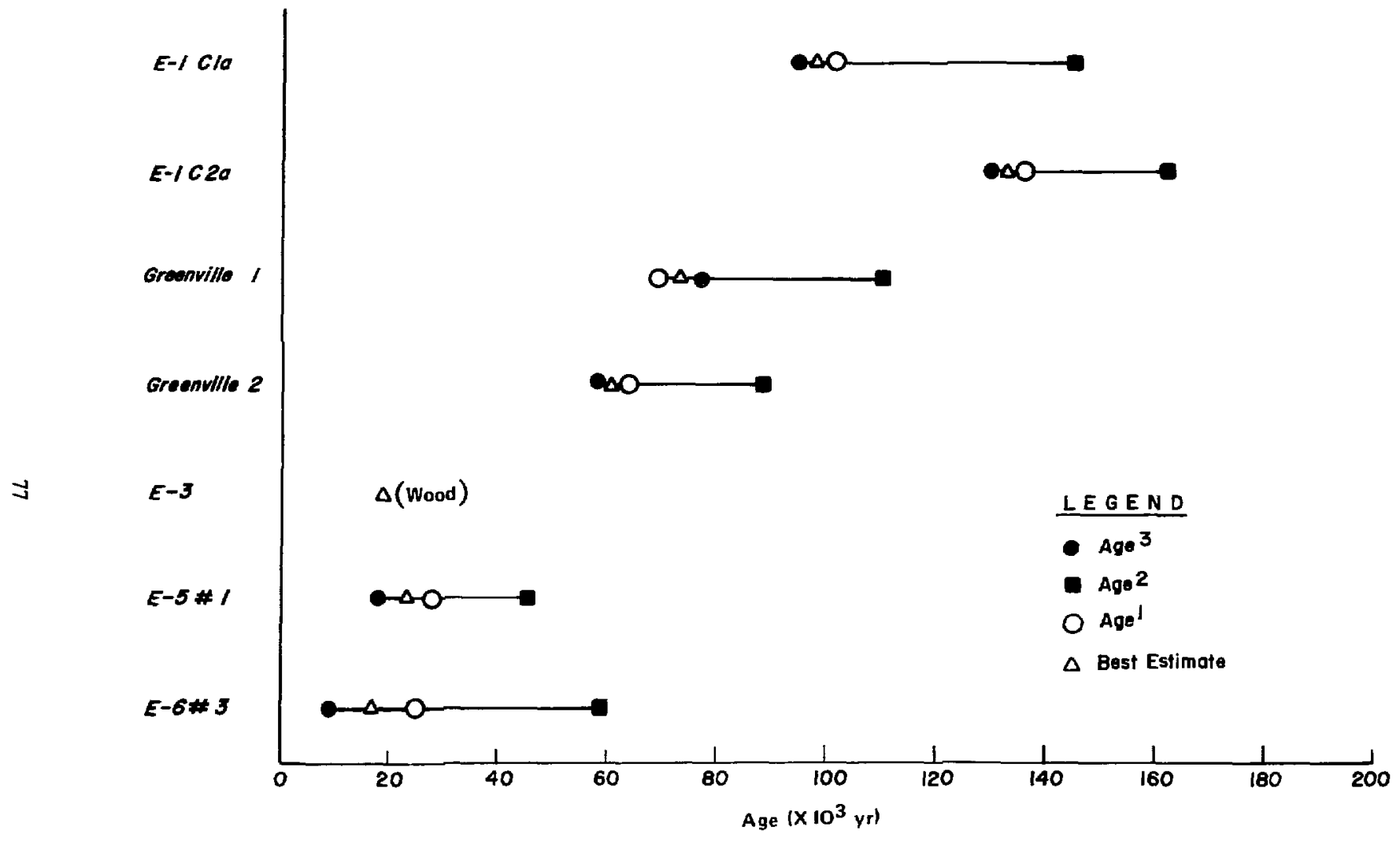

FIG. C-1. Summary of age determinations for one wood and six pedogenic carbonates in samples taken from trenches and roadcuts in the Livermore Valley. 
to be made on the internal consistency of our data as well as their conformity with any relative age estimates of the alluvial units based on geomorphic evidence. The combinations of young and old potential $\mathrm{C}$ sources for these pedogenic carbonates precludes the use of ${ }^{14} \mathrm{C}$ methods. In addition, this technique is limited to approximately a 40000 yr range whereas many of the buried paleosols encountered are clearly older than that, as estimated from geomorphic evidence.

The individual caliche dates represent average ages of the entire thickness of carbonate included in each analysis. The lime elapsed in accreting this carbonate is unknown. In addition the rates of accretion may have been more rapid during pluvial times in the Pleistocene.

The reliability (precision) of the ages may be inferred by a consideration of the two pairs of coeval samples analyzed; E-1 Cla to E-1 C2a and Greenville Rd. \#1 to Greenville Rd. \#2. The data have been summarized in Table $\mathrm{C} .4$ and include the mean and standard deviation in the various model ages. The precision of approximately \pm 10 to $20 \%$ is comparable to that observed in analyses of presumed coeval pedogenic carbonates by Ku et al, (1979). Because of the difficulty in assessing the initial ${ }^{230}$ Th activities, dating impure carbonates by these methods will probably have inherent uncertainties of this magnitude. Nevertheless, as there are no other absolute dating tools for these deposits, limitations of precision of such magnitude can certainly be tolerated at this time.

In this preliminary effort it is important to consider the radiochemical nature of the noncarbonate detrital minerals because they are important to the assumptions used in correcting the leachate data. Some knowledge can be gathered by inference from the data on residues. As seen from Table C-2, the uranium and thorium concentrations in the residues are in the range 1 to $8 \mathrm{ppm}$, with an average Th/U weight ratio of $3: 1$, These values are generally expected from an average shale. The ${ }^{234} \mathrm{U} / 238 \mathrm{U}$ activity ratios are near the secular equilibrium value (average 0.94), Ku et al. (1979) have determined that criteria can be specified by which large deviations from these nornis can be used to identify sumples unsuitable for dating by these methods.

Analyses of several of the samples did not give reliable age estimates. Three samples all had carbonate contents less than $60 \%$ by weight, whereas more reliably dated samples are above this amount. Furthermore, these three samples all had low leachate ${ }^{230} \mathrm{Th} /{ }^{232} \mathrm{Th}$ ratios compared to other samples, indicating that they contain a significant detrital or common thorium component in the leachate (carbonate) fraction. Because of the uncertainty in initial ${ }^{230} \mathrm{Th}$ content of the carbonate, the ages were less reliable and ranged widely. Ages for these sumples (E-2 \#2, E-6 \# l, and Bldg. 391 excavation) are not included in the interpretive discussion in the text.

TABLE C-4. Age estimates of coeval pedogenic carbonates.

\begin{tabular}{|c|c|c|c|c|c|c|}
\hline Sample & $\begin{array}{c}\text { Age } \\
\left(\times 10^{3} y\right)\end{array}$ & Mean' & Age $^{2}$ & $\operatorname{Mean}^{2}$ & $\mathrm{Age}^{3}$ & Meun $^{3}$ \\
\hline \multirow[t]{2}{*}{ E-1 Cla } & 100 & & 145 & & 95 & \\
\hline & & $118 \pm 24$ & & $153 \pm 12$ & & $113 \pm 24$ \\
\hline E-I C2: & 135 & & 162 & & 130 & \\
\hline \multicolumn{7}{|l|}{ ropentille } \\
\hline \multirow[t]{2}{*}{$x d$} & 70) & & 110 & & 77 & \\
\hline & & $67 \pm 5$ & & $99 \pm 15$ & & $68 \pm 13$ \\
\hline \multicolumn{7}{|l|}{ Corsmuitle } \\
\hline liti. $f$ & 63 & & 88 & & 58 & \\
\hline
\end{tabular}




\section{CONCLUSIONS}

Although Trench E-3 contained no caliche, which would provide a direct concordancy check with the wood fragment acquired, concordancy can be indirectly inferred. The wood fragment in Trench E-3 was taken from Qoa 2 material. Two carbonate samples from other trenches, also taken from Qoa, material, corroborate the date. Preliminary results indicate that the method of Ku et al. (1979) may be extended to semiarid region pedogenic carbonate as well as to other non-pedogenic carbonate cementations resulting from the actions of ground and surface waters. Secondary carbonales may provide useful information about stratigraphic relationships between various alluvial units within the Livermore Valley. Under appropriate conditions, absolute ages may be obtainable with better than $\pm 20 \%$ precision. This is a tolerable level of precision when one considers that no other absolute dating techniques are available. In appropriate situations, relationships between disturbed and undisturbed units allow one to deduce a minimum age for fault movement or to potentially bracket ages.

Puleoseismicity in the Livermore area may possibly be determined by exanining the depositional record contained in Frick Lake. Slumping or other disturbunces would reflect the various seismic events. It may also be possible to age date sediment horizons beneath this playa lake by age dating the marls resulting from desiccation or other freshwater carbonates-such as pelecypods, gastropods, or tufa-using uraniumseries age dating techniques. This work would complement any palcomagnetic determinations made on the playa sediments. 


\section{APPENDIX D \\ GEOPHYSICAL EXPLORATION}

by Paul Kasameyer

\section{DIPOLE-DIPOLE RESISTIVITY SOUNDINGS}

Dipole-dipole resistivity soundings were performed along five profiles in the field east and south of SNLL to evaluate the usefulness of this survey method and to search for features aligned parallel to either the Tesla or Las Positas fault trends, Locations of the profiles are shown in Figs, D-1 and 31. Data were collected by N. Chakakis, R. Egbert, and J. Sweeney, A Scintrex transmitter and IPR 8 receiver were used with steel rod electrodes at spacings of 100 and $200 \mathrm{ft}$. Results are shown in Figs, D-3 to D-7, which contain apparent resistivity pseudo-depth sections showing data obtained by the method described in Fig. D-2,

Apparent resistivity pseudo-sections calculated for two-dimensional earth models have been compared to the $100 \mathrm{ft}$ separation data. (J. Sweeney, LLNL internal memo AG $80-20$, revision). The primary features of the conclusions reached are discussed here.

First, the general features of the known geology are reflected in the interpreted resistivity crosssections. A thin (less than $10 \mathrm{ft}$ ), relatively conductive $(20 \mathrm{~s} \cdot \mathrm{m}$ ) weathering layer was observed in many places. The alluvium (Qal) in the flat areas was also conductive $(20-30 \Omega \cdot m)$ and the outcrops of Livermore Gravels (QTI) that form hills were relatively resistive $(50-60 \Omega \cdot \mathrm{m})$ to depihs of $50-100 \mathrm{ft}$. This difference in resistivity could reflect the lower clay content of the Livermore Formation or a difference in elevation of the water table related to the topography. A prism of low resistivity is seen beneath the South Bay aqueduct, perhaps indicating increased water content, clay, or salinity in the rock beneath the aqueduct. The interpreted resistivity at $50 \mathrm{ft}$ depth is indicated by the shading in Fig. D-1.

Second, two lines (2 and 6 ) cross the trace of the Tesla \#1 fault. They show no indication of lateral changes in resistivity due to rock type and are thus in agreement with the 1978 URS/Blume report in this area. Line 2 lies entirely in the alluvium and its pseudo-section is quite featureless, indicating relatively uniform resistivity to depths of at least $100 \mathrm{ft}$. Line 6 lies in the Livermore Formation and is nearly parallel to the aqueduct. Along much of its length the profile was located close enough to the aqueduct to sense the low resistivity prism. Consequently, the pseudo-section is complex and other features may be hidden. The zone of low resistivity under the aqueduct broadens near pin 12 of line 6; reasons for this broadening are not known.

Third, lines 3, 4 and 5 cross the trend of the Las Positas Fault. The boundary between high resistivity rocks (inferred to be QTI) and low resistivity rocks (inferred to be Qal) strikes approximately parallel to the trend of the Las Positas Fault. The location of that contact can best be determined on line 5, since the boundary is obscured by the aqueduct anomaly on lines 3 and 4 . On line 5 , the boundary is seen to fall within $\pm 50 \mathrm{ft}$ of pin 6 . This boundary does not align with faults identified in the Sandia outcrop. An extension of the boundary to the southwest would pass through the east end of trench E-3 and pass to the northwest of trench E-4.

More modeling and measurements would be required to determine the nature of the boundary, i.e. whether it is abrupt or gradual, or whether similar beds appear on opposite sides at different depths. One possible interpretation is that the relatively resistive rocks on the northwest side of the boundary are $50 \mathrm{ft}$ deeper than on the southeast side.

\section{SEISMIC REFLECTION DATA}

Gasch and Associates, Inc. ran two small-scale, high resolution seismic reflection profiles on the LLNL site (Fig. 18). They were not given information about previous seismic refraction data taken on the site, and were not asked to interpret their results. These datu were collected for the purposes of: 
1. Providing a means of evaluating the quality of data collected by a contractor.

2. Determining whether reflectors at moderate depths (200-500 ft) could be detected by the seismic reflection technique.

Descriptions of data collection and processing, as well as common-depth-point stacked sections, are contained in their report (Gasch and Associates, Inc, Project \#GA79042, 1979). From our examination of these results and unprocessed data we conclude that:

1. Electronic problems caused data to be of poor quality and led to uncertainty in determining shot time.

2. Critically refracted energy corresponding to a layer $100-150 \mathrm{ft}$ deep with an apparent seismic velocity of about $6000 \mathrm{ft} / \mathrm{s}$ is seen on the unstacked records. This energy contaminates the stacked sections, which are constructed assuming all energy is from reflections.

3. Strong, easily identifiable reflections are not seen in the raw data, nor do they appear in the processed data. The processed sections do show some short scale coherence, but cannot be interpreted. The lack of strong continuous reflections may be caused by discontinuous layering, by inadequate recording, or by inappropriate processing because of lack of knowledge about the velocity structure.

Before more reflection work is considered, we will perform small scale seismic refraction work on several areas.

\section{MAGNETIC DATA}

Total magnetic field surveys have been made on the LLNL site and east of SNLL (see Figs, 18 and 31). Measurements made in these surveys and the measurements published in the Blume (1972) and URS/Blume (1978) reports refleci effects of man-made features such as pipes and fences. All available data are being plotted and examined for indications of faults.

\section{SELF POTENTIAL}

Self potential measurements are being made in the vicinity of the Las Posilas Fault to see if possible strands of that fault cain be located by self potential methods. 


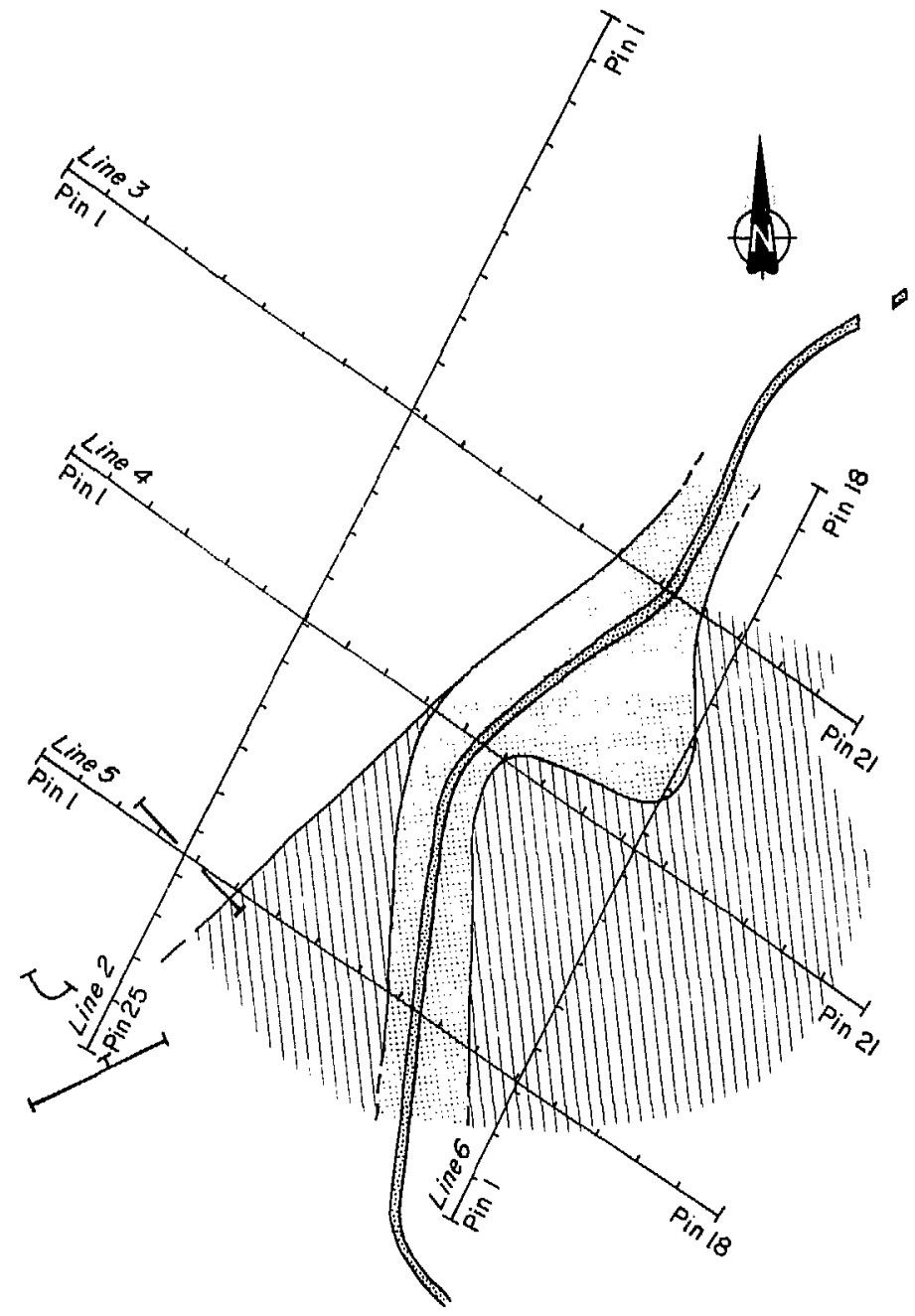

FIG. D-1. Map of survey lines for dipole-dipole resistivity in field southeast of SNLL. The tick marks on the profile lines represent locations of survey pins with $100 \mathrm{ft}$ spacing. The pin numbers are also shown on the top of the pseudo sections in Figs. D-3 to D-7. The resistivities interpreted to be at a depth of 50 ft are indicated by shading. 


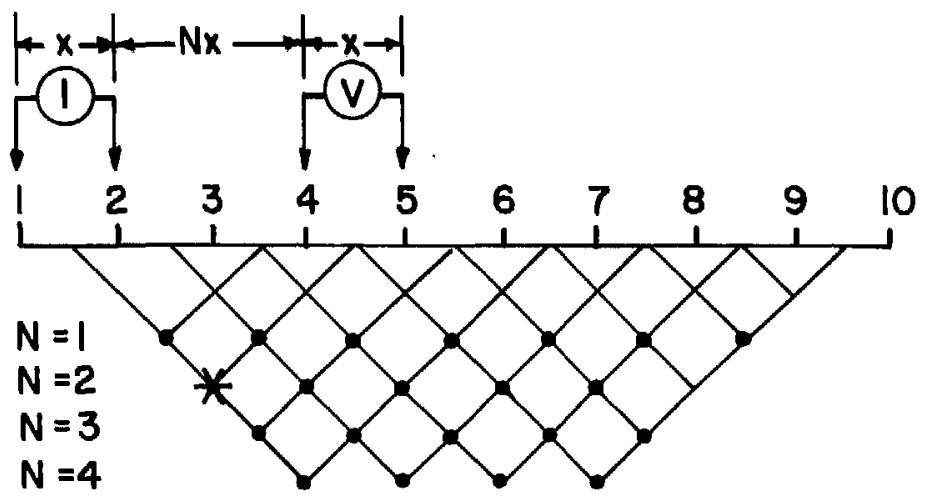

FIG. D-2. Method for plotting apparent resistivity pseudo-depth sections. Current and voltage dipoles of fixed length $\times$ ( 100 or $200 \mathrm{ft}$ ) are placed along the line as shown. The detected apparent resistivity is a spatial average of the earth resistivity below the line. As the dipole spacing $\mathrm{Nx}$ is increased, the earth resistivity is averaged over a greater depth. To produce the pseudo-depth section, the apparent resistivity is plotted on the line of the appropriate $N$ value and midway between the dipoles. The star indicates the plotting position for the measurement geometry shown. The pseudo-depth section is a convenient way to plot dipole-dipole data, but does not represent an accurate map of the subsurface because each measurement averages over a large volume. 

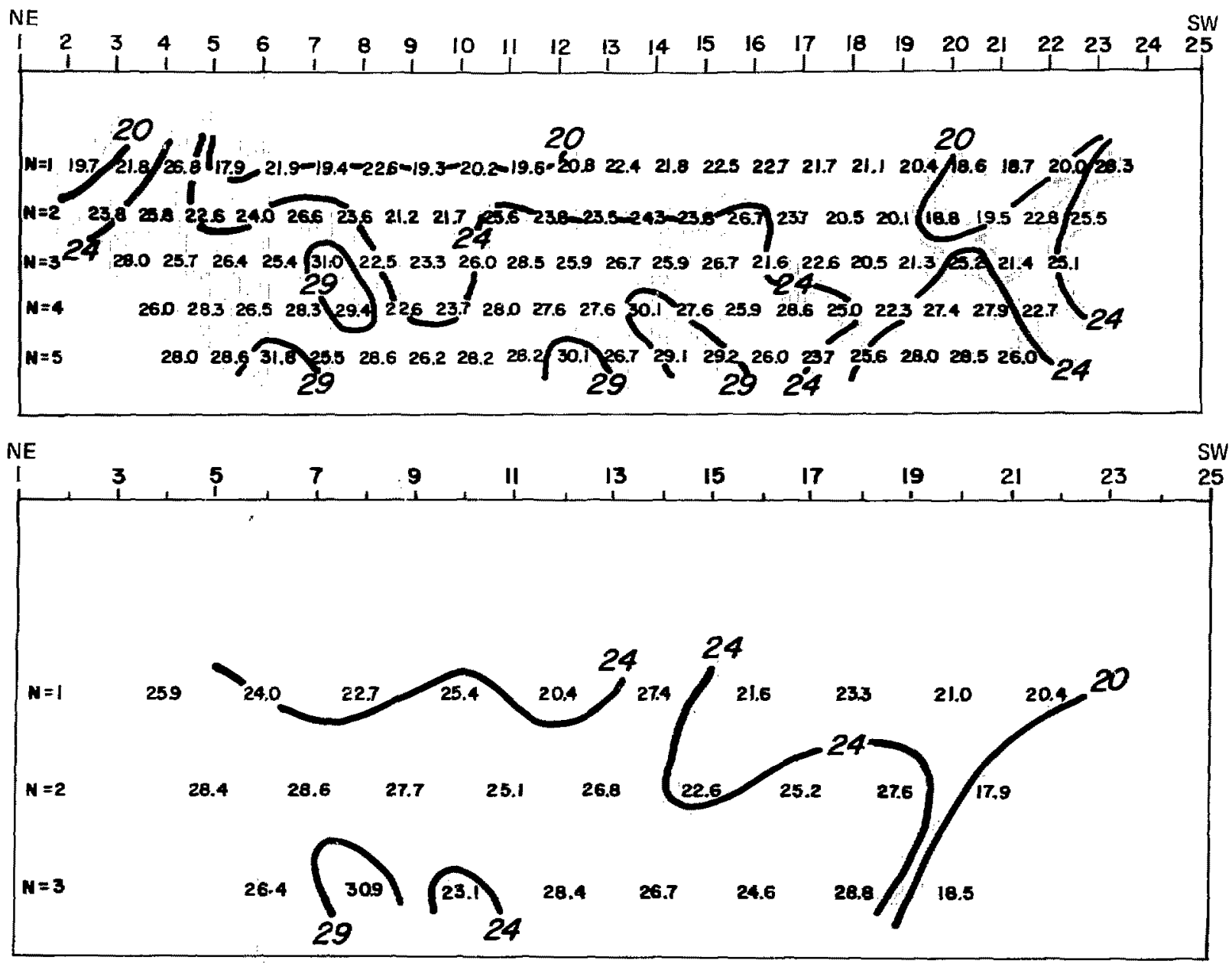

FIG. D-3. Apparent resistivity pseudo-dep th sections along line 2. Run 1, the upper section, contains data taken with $100 \mathrm{ft}$ dipoles. Run 2, the lower section, represents data taken with 200 ft dipoles. For these and all following sections, each contour represents approximately a $20 \%$ increase in apparent resistivity. 


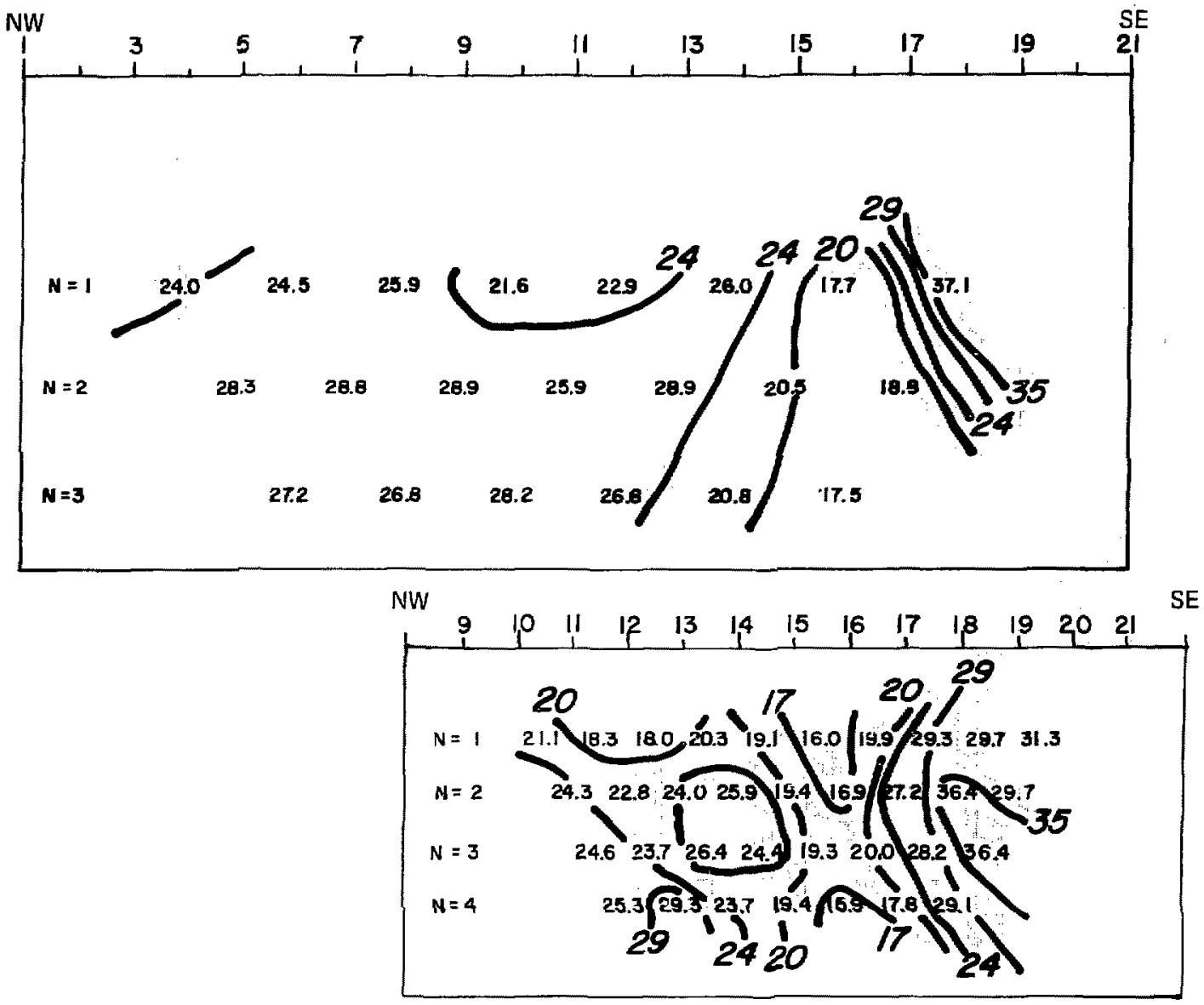

FIG. D-4. Apparent resistivity pseudo-depth sections along line 3. Run 1, the upper section, represents data taken with $200 \mathrm{ft}$ dipoles. Run 2, the lower section, represents data taken with $100 \mathrm{ft}$ dipoles. 


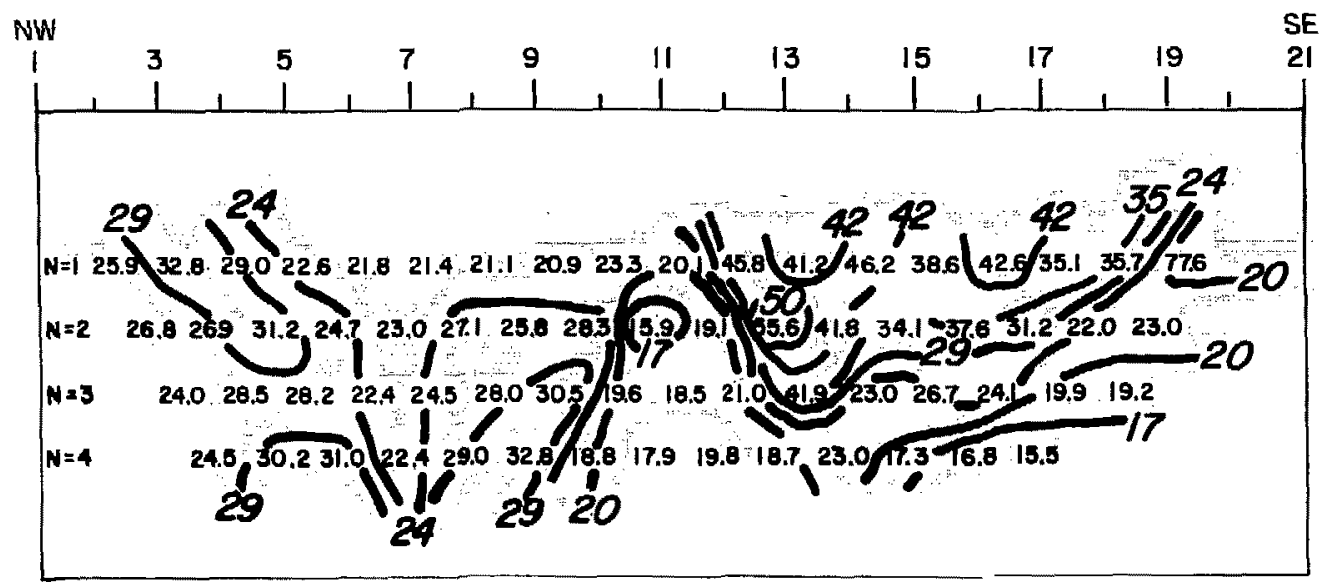

FIG. D-5. Apparent resistivity pseudo-depth section along line 4, taken with 100 ft dipoles.

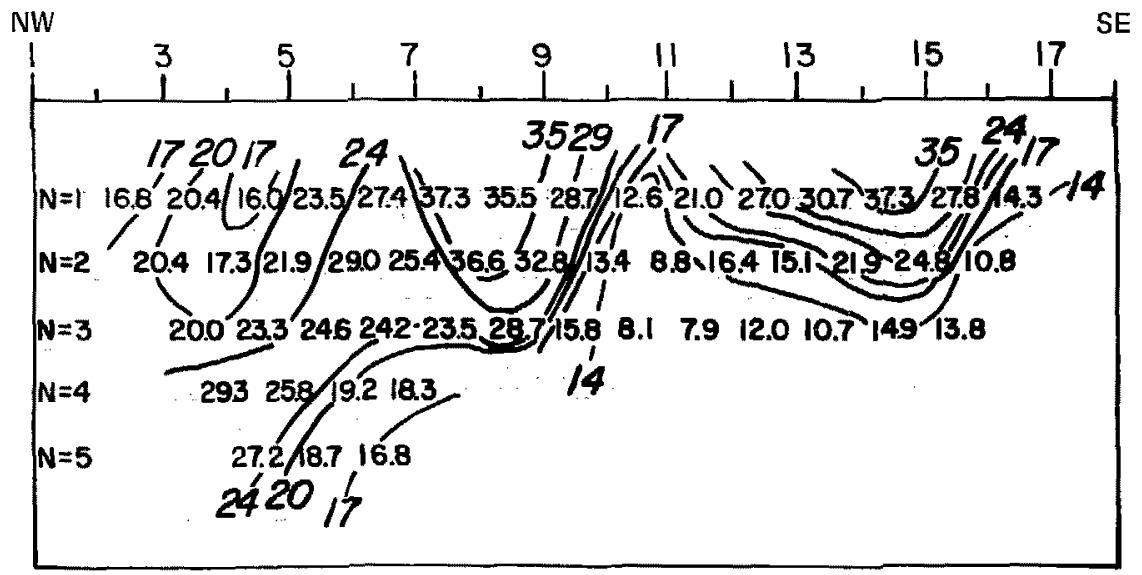

FIG. D-6. Apparent resistivity pseudo-depth section along lint 5, taken with 100 ft dipoles. 


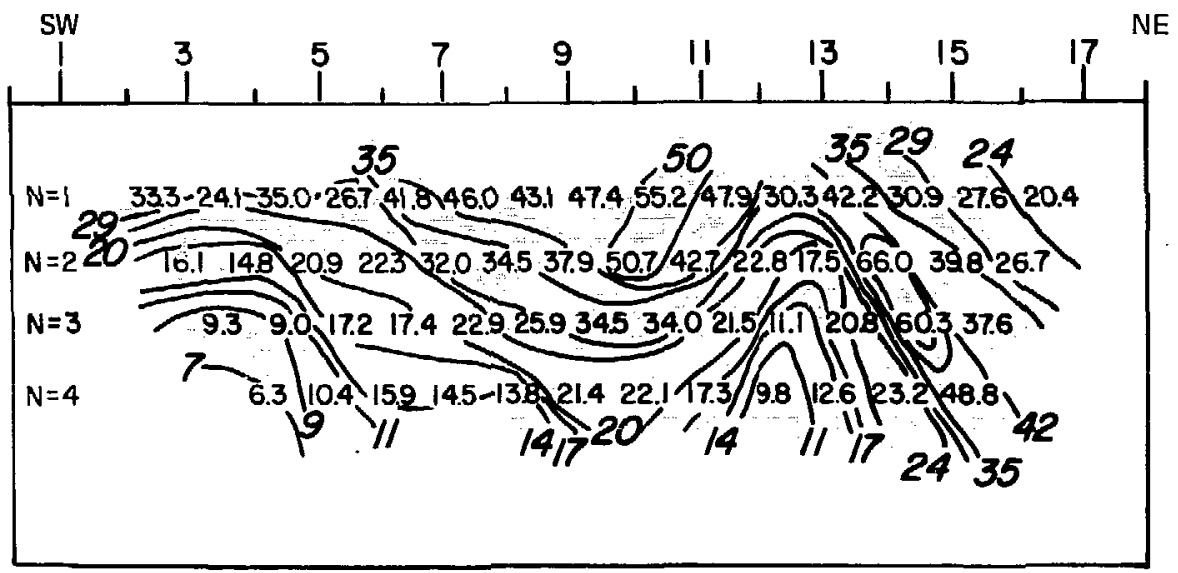

FIG. D-7. Apparent resistivity pseudo-depth section along line 6, taken with 100 ft dipoles. 


\section{APPENDIX E \\ FIELD OBSERVATIONS OF SURFACE FAULTING \\ Livermore Valley earthquake series, January 24, 1980 and following}

The source of the following observations is Bonilla and others, 1980. Location numbers shown appear on Figs. 20 or 32. Locations 1-32, 37, 38 appcar on Fig. 20 and locations 33-36 on Fig. 32.

\begin{tabular}{|c|c|}
\hline Location & Observations \\
\hline 1 & $\begin{array}{l}\text { Zone } 100 \mathrm{~m} \text { long, trends } \mathrm{N} .47^{\circ} \mathrm{W} . \text {; individual open fractures in soil trend } \\
\mathrm{N} .25^{\circ} \mathrm{W} .-35^{\circ} \mathrm{W} \text {., have left-stepping en echelon relation to the zone. At one point, } \\
\text { right latcral displacement of } 11 \mathrm{~mm} \text { parallel to zone and extension of } 20 \mathrm{~mm} \text { per- } \\
\text { pendicular to zone ( } 1 \mathrm{Fcb} \text {.). Local minor left-lateral component, probably from } \\
\text { downslope gravity movement. }\end{array}$ \\
\hline 2 & $\begin{array}{l}\text { Zone trends } N .30^{\circ} \mathrm{W} \text {, consists of at least } 7 \text { fractures in soil, on most of which } \\
\text { right lateral separation could be seen. Site of survey quadrilateral installed by } \\
\text { P. W. Harsh. Zone may extend } 40 \mathrm{~m} \text { farther NW where a pair of left-stepping } \\
\text { fracturcs could be followed for } 15 \mathrm{~m} \text {; extends at least } 20 \mathrm{~m} \text { to SE. Includes small } \\
\text { graben with maximum depth of } 70 \mathrm{~mm} \text {. }\end{array}$ \\
\hline 3 & $\begin{array}{l}\text { Zone trend } \mathrm{N} .30^{\circ} \mathrm{W} \text {. consists of discontinuous fractures that trend } \mathrm{N} .30^{\circ}-35^{\circ} \mathrm{W} \text {. } \\
\text { A taut root and match of pebble with its mold provided calculated right lateral } \\
\text { displacements of } 18 \mathrm{~mm} \text { parallel to zone and extension of } 47 \mathrm{~mm} \text { perpendicular to } \\
\text { zone. }\end{array}$ \\
\hline 4 & $\begin{array}{l}\text { Zone trend } \mathrm{N} .38^{\circ} \mathrm{W} \text {. individual cracks generally show relative uplift (max. } \\
50 \mathrm{~mm} \text { ) of northeast side and as much as } 30 \mathrm{~mm} \text { extension; a "bridge" of sod at- } \\
\text { tached to both walls indicated a right lateral component. }\end{array}$ \\
\hline 5 & $\begin{array}{l}\text { Two isolated en echelon left-stepping fractures in dirt road indicate right-lateral } \\
\text { displacement but unable to measure amount. Northeast of line joining locations } 4 \\
\text { and } 5 \text { are some short fractures that are probably related to downslope gravity } \\
\text { movements, although one showed } 6 \mathrm{~mm} \text { of right-lateral separaion combined with } \\
27 \mathrm{~mm} \text { extension. Between locations } 5 \text { and } 6 \text { and on both sides of a line joining } \\
\text { them is an area of extensive landsliding. }\end{array}$ \\
\hline 6 & $\begin{array}{l}\text { Prominent fracture in soil, at least } 30 \mathrm{~m} \text { long; trends } \mathrm{N} .36^{\circ} \mathrm{W} . \text {; strong suggestion } \\
\text { of right-lateral component based on differences in crack width and probable } \\
\text { match of points across break; relative vertical displacement mostly down on } \\
\text { downhill side but not consistent. Survey alinement array installed by P. W. Harsh } \\
\text { on } 26 \text { January crosses this fracture. }\end{array}$ \\
\hline 7 & $\begin{array}{l}\text { A pair of fractures, in soil, that intersect an E.-W. fence on the half-section line. } \\
\text { West fracture trends } \mathrm{N} .27^{\circ}-32^{\circ} \mathrm{W} \text {. shows mostly downhill extension (maximum } \\
\text { vertical } 90 \mathrm{~mm}, 6 \mathrm{Feb} \text { ) but may have a right lateral component. Extends south of } \\
\text { fence where it becomes part of a landslide studied by } \mathrm{R} \text {. V. Sharp. About } 2.4 \mathrm{~m} \text { to } \\
9.8 \mathrm{~m} \text { east is another fracture, somewhat concave upslope in plan, with a general } \\
\text { trend of about } \mathrm{N} .28^{\circ} \mathrm{W} \text {. This fracture is in compression with thrusting of } \\
\text { downhill side over uphill side; maximum vertical component } 70 \mathrm{~mm} \text {. The one } \\
\text { place where lateral component could be inferred ( } 6 \mathrm{Feb} \text { ) indicates left lateral, but } \\
\text { very uncertain. The origin of these fractur } \mathrm{i} \text { is not clear. }\end{array}$ \\
\hline
\end{tabular}


Fracture zone in soil, trend $\mathrm{N} .27^{\circ} \mathrm{W}$, consists of left-stepping fractures, extends $\mathrm{SE}$ from N-S fence that is on the quarter-section line. Right-lateral displacement parallel to zone at two points ( $28 \mathrm{Jan}$ ) ranged from $10 \mathrm{~mm}$ to $25 \mathrm{~mm}$. Farther to NW are other fractures with the same trend but they may not be of tectonic origin.

Fracture zone in soil, trend $\mathrm{N} .27^{\circ} \mathrm{W}-30^{\circ} \mathrm{W}$, traced $52 \mathrm{~m}$. Unable to match edges of fracture to measure right-lateral displacement but could be a few centimeters.

Single fracture in soil, trend $\mathrm{N} .30^{\circ} \mathrm{W}$, right-lateral strike slip $8 \mathrm{~mm}$, calculated parallel to average zone trend of $\mathrm{N}, 44^{\circ} \mathrm{W}$. Between locations 10 and 11 the fault trace was visible at several places; although evidence of right-lateral displacement was seen, we could not measure it.

Left-stepping fractures in soil; measured $22 \mathrm{~mm}$ of right-lateral strike slip 1 February which had increased about $1 \mathrm{~mm}$ when remeasured 6 February. Unable to find fault traces between localities 11 and 12 .

At Vasco Road. Pressure ridges and fractures formed in the pavement which is built on artificial fill. At time of our detailed examination (28 January) the pressure ridges had been removed and many of the edges of the fractures had teen modified by truck traffic, but right-lateral strike-slip displacement was estimated at about $2 \mathrm{~cm}$ parallel to the zone trend of $\mathrm{N} .30^{\circ} \mathrm{W}$. Fault traces were not visible within $0.5 \mathrm{~km}$ SE of Vasco Road.

Road to East Alameda County Dump. Seven hairline fractures extending perpendicularly across this paved road were visible 31 January; at least four cracks were present 25 January. Most of the cracks lie near the projection of the main break, have a NE trend, and may represent incipient faulting.

A short fracture zone, trend $\mathrm{N} .40^{\circ} \mathrm{W}$., was found in soil at the base of a scarp-like rock outcrop. Individual fractures trend about N.18 ${ }^{\circ} \mathrm{W}$. Right-lateral strike slip was $8 \mathrm{~mm}$ parallef to zone and extension was $4 \mathrm{~mm}$ perpendicular to zone on 30 January.

Zone of fractures in soil; individual fractures trend N-S; probable right-lateral strike-slip.

Fracture zone trending about $\quad$ :. $30^{\circ} \mathrm{W}$, crosses Laughlin Road; first observed by us on 25 January. Individual fractures trend N-S, step to left. Difficult to confidently match points across the fractures but strike slip parallel to zone may be as much as $6 \mathrm{~mm}$ on a single break (29 February) including afterslip. Fractures could be traced NW into cultivated field but we did not see them to the SE of the pavement. Between locations 16 and 17 several hairline cracks with no displacement cross the pavement approximately perpendicular to the road.

A fracture trending $\mathrm{N} .19^{\circ} \mathrm{W}$. showing about $3 \mathrm{~mm}$ of right lateral displacement (measured parallel to crack; $28 \mathrm{Jan}$ ) in dirt NE of pavement.

Group of northeast-trending fractures in pavement. The most conspicuous one trends N. $7^{\circ} \mathrm{E}$. Slip vectors measured at two places on this fracture 29 February were $13 \mathrm{~mm}$ in $\mathrm{N} \cdot 20^{\circ} \mathrm{W}$. direction and $15 \mathrm{~mm}$ in $\mathrm{N} \cdot 25^{\circ} \mathrm{W}$. direction. Resolved parallel to trend of zone (between localities 18 and 19) the right lateral strike slip was about 14 to $15 \mathrm{~mm}$; right lateral displacement resolved parallel to the fracture ranged rom 12 to $13 \mathrm{~mm}$, of which as much as $6 \mathrm{~mm}$ occurred after a white line was painted across the fracture by Woodward-Clyde consultants on 25 January. 
On 29 February extension perpendicular to the fracture was as much as $8 \mathrm{~mm}$, and vertical separation near center of road was as much as $2 \mathrm{~mm}$ (down to SE) but was not detectable at edges of road. Only one hairline fracture was observed at this locality on 25 January. The fracture had widened and moved $2 \mathrm{~mm}$ rightlaterally by 13 February; many more fractures were present on 13 February than on 25 January, indicating that they were related to the 26 January event or subsequent movement.

Fracture zone in shoulder of road crossed low cut at SW edge of right-of-way and extended into field. On 28 January right-lateral displacements were $7 \mathrm{~mm}$ resolved parallel to fracture zone and $6 \mathrm{~mm}$ resolved parallel to the direction between locations 18 and 19. Site of alinement array installed by P. W. Harsh 30 January.

More than 20 hairline fractures in the pavement of Laughlin Road. Spacing between fractures (29 January) ranged from $1 \mathrm{~m}$ to $20 \mathrm{~m}$ and trends ranged from about $\mathrm{N} .40^{\circ} \mathrm{W}$. to about $\mathrm{N} \cdot 60^{\circ} \mathrm{W}$, diagonal to the road. The number of fractures increased thru time-only two fractures were visible on 25 January.

Fractures between locations 21 and 22 cross frontage road $\mathrm{N}$ of Interstate 580 perpendicularly. Some, perhaps all, are old fractures in the pavement that apparently opened wider during the earthquakes.

Intersection of Greenville Road and frontage road. Several fractures, some old (possibly associated with previous seismic events) and some apparently new. Nearly all confined to asphalt pavement and not breaking concrete curbs; orientation about N-S. One conspicuous crack on N-S part of Greenville Road showed (29 January) extension of $6 \mathrm{~mm}$, no lateral displacement, did not break the concrete divider and died out to south within $11 \mathrm{~m}$.

Between locations 22 and 23 are at least 17 fractures, most if not all old, but with additional extension presumably at the time of the earthquakes. Spacing between fractures ranges from about 3 to $73 \mathrm{~m}$ with concentrations of fractures in certain areas. The fractures show only extension except for one at location 23; there a fracture trending about $\mathrm{N} .40^{\circ} \mathrm{W}$. showed about $1 \mathrm{~mm}$ of right-lateral displacement (29 January) and $2 \mathrm{~mm}$ of extension. The right lateral component had increased to about $2 \mathrm{~mm}$ on 29 February and to $3 \mathrm{~mm}$ on 1 April. The fracture was best developed in the north part of the road. It did not reach the south edge of the pavement on 29 January, but did by 1 April, It could not be seen in the dirt north or south of the pavement. This location is directly on the projection of a fault shown by Herd (1977) within the Greenville fault zone.

South frontage road of I-580, west of Greenville Road. Examined in reconnaissance fashion 29 February. At least 21 fractures, perpendicular to the road, show only extension except for one about $160 \mathrm{~m}$ west of the centerline of Greenville Road which has a suggestion of less than $1 \mathrm{~mm}$ of right lateral displacement. Close to Greenville Road are several fractures most if not all of which are old; apparent right lateral displacement ( $1 \mathrm{~mm}$ or less) on two of them seems to be the result of vertical movement of the inclined face of the concrete curb. Fractures on Greenville Road are mostly perpendicular to that road and at right angles to the fractures on the frontage road.

On Vasco Road about $2 \mathrm{~km}$ north of the County line. Several right-stepping fractures in the pavement. One zone trends about N. $70^{\circ} \mathrm{E}$., crosses entire pavement and showed 1 to $2 \mathrm{~mm}$ of left lateral and up to $3 \mathrm{~mm}$ vertical displacement (side up not consistent) on 6 February; a subparallel zone a few meters away shows 
only extension (maximum $5 \mathrm{~mm}$ ), doesn't reach northeast side of pavement but visible in dirt on southwest side of pavement. Unable to find fractures beyond shoulder of road. Roadbed probably on bedrock (sandstone and shale dipping $30^{\circ} \mathrm{S} .50^{\circ} \mathrm{W}$.) but thin fill could be under pavement.

Fracture zone in scil, trend $\mathrm{N} .38^{\circ} \mathrm{W} .$, could be traced about $30 \mathrm{~m}$ by very careful search, including pulling of grass. Zone at least $5 \mathrm{~m}$ wide, consists of three or more fractures up to $5 \mathrm{~mm}$ wide, about parallel to zone. Except for a left-stepping pattern in places, no evidence of lateral movement was found. Other fractures to the east, on a northeast-facing slope probably result from downslope movement of the soil.

Fracture zone in soil, trend $\mathrm{N} .55^{\circ} \mathrm{N}$. (sic), was traced $43 \mathrm{~m}$. lt consists of prominent discontinuous left-stepping fractures. Near south end, differences in widths of fracture indicate a left-lateral component, but $15 \mathrm{~m}$ to the northwest had $15 \mathrm{~mm}$ of right-lateral strike slip measured parallel to trend of zone; southwest side generally downdropped, the vertical component being as much as $20 \mathrm{~mm}$ locally.

Fracture zone in soil, trend $\mathrm{N} .48^{\circ} \mathrm{W}$, traced about $45 \mathrm{~m}$. Near middle of zone, left-lateral strike slip $10 \pm 5 \mathrm{~mm}$, extension about $30 \mathrm{~mm}$, and vertical component (down to $\mathrm{SW}$ ) about $30 \mathrm{~mm}$. About half way between locations 22 and 28 is a fracture zone locally trending N.58 ${ }^{\circ} \mathrm{W}$. At one point on it both the extension and the vertical component (down on $\mathrm{SW}$ ) about $20 \mathrm{~mm}$ and the right-lateral strikeslip component was $11 \mathrm{~mm}$ and $7 \mathrm{~mm}$ resolved parallel to the local zone trend and general zone trend respectively.

At Vasco Road breaks in the pavement had been repaired at time of our visit except near centerline of road, where there were three principal cracks that formed a zone about $1 \mathrm{~m}$ wide, and a vertical component (down on $S W$ ) was visible. About $3: 30 \mathrm{pm}$ on 24 January, just before the repairs were made, R. C. Wilson and D. K. Keefer measured and photographed the break at the southeast side of the road where it was a single fracture. At the white line there they measured $20 \mathrm{~mm}$ of right lateral displacement, $40 \mathrm{~mm}$ of extension, and $30 \mathrm{~mm}$ of vertical displacement, down on southwest. Because the white line is perpendicular to the fault, its lateral displacement represents right slip. Later visits showed that additional displacement represents right slip. Later visits showed that additional displacements have cracked the asphalt that was placed 24 January. This fracture zone could be followed continuously (25 January) as open cracks in the soil for at least $100 \mathrm{~m}$ nor thwest of Vasco Road and about $30 \mathrm{~m}$ southeast. About 40 m northwest from the road on 5 February the fracture showed $20 \pm 10 \mathrm{~mm}$ of left lateral displacement measured parallel to the fracture (locally N.26 ${ }^{\circ} \mathrm{W}$.) and some vertical displacement (down on $\mathrm{SW}$, the downhill side).

Fracture zone in soil, general trend about $\mathrm{N} .45^{\circ} \mathrm{W}$., was traced for $45 \mathrm{~m}$. At one point right-lateral strike slip parallel to zone was $13 \mathrm{~mm}$ and the extension was $24 \mathrm{~mm}$, with no vertical component. This site is on top of a flat spur with a slight inclination to the southeast. Southeastward from this fracture zone others were found in the next $50 \mathrm{~m}$; these were open, generally had no vertical component and in places showed a left-stepping pattern.

Fracture zone in soil, general trend N.45 ${ }^{\circ} \mathrm{W}$, could be followed for $2 \% \mathrm{~m}$. At one point extension was about $25 \mathrm{~mm}$, vertical component $27 \mathrm{~mm}$ (down to $\mathrm{SW}$ ), and 
right-lateral strike slip was $8 \mathrm{~mm}$; downslope movement alone would have given a left-lateral component. No other fractures were found to the southeast along the trend of this fault zone.

West of Vasco Road in W. $1 / 2$ sec. 23, T. 25, R. 2 E. Fracture trending N.30 W. extends discontinuously for at least $0.3 \mathrm{~km}$, extending over a hilltop, across a valley and up another hillside where access problems prevented a further search. Fracture shows mostly extension but at several places a right-lateral component was found. The maximum measured right-lateral strike slip was $5 \mathrm{~mm}$ combined with $6 \mathrm{~mm}$ of extension, both resolved with respect to the map trend of $N, 33^{\circ} \mathrm{W}$,

At Mines Road eight sets of fractures designated $33 \mathrm{~A}-33 \mathrm{H}$ were observed on 7 February. The fructures are located 210 to $250 \mathrm{~m}$ south of the centerline of Tesla Road. Azimuths of segments of the fractures range from $76^{\circ}$ to $109^{\circ}$ but trend approximately perpendicular to Mines Road; the fractures are largely confined to the northbound lane. Only 33A was noted to extend across the centerline on 7 February. Prior to 7 February, other investigators used orange spray paint to mark fractures 33A, 33B and 33C; fractures 33D-33H had not been painted. On $\mathcal{7}$ February, no measurable vertical or lateral displacements were associated with the fructures $33 \mathrm{~A}-33 \mathrm{H}$. No apparent post-paint propagation or extension of fractures $33 \mathrm{~A}-\mathrm{C}$ was observed,

On 29 February location 33 was reinspected. Blue paint had been applied to fractures 33D-33H. Fracture 33G now crossed the centerline of Mines Road, but had not grown since application of the blue paint. No displacements or apparent propugation of fractures other than 33G was observed.

The fractures exhibited dusty, weathered surfaces and did not expose freshly broken, black asphalt as did other fractures caused by tectonic displacement or by non-tectonic ground failure. Although fractures 33A-33C apparently coincide most closely with the trace of the Las Positas Fault (Herd, 1977), the absence of measurable displacement and the rather aged appearance of the fractures and their geometry (perpendicular to Mines Road) suggests a non-tectonic origin. The extension of fracture 33G across the centerline of Mines Road observed on 29 February followed a period of heavy rain. The extension of this feature if tectonic in origin, is the apparent southwestern limit of effects related to postulated surface rupture on the Las Positas Fault.

Tesla Road (inspected 7 February) nine fractures comprise three right-stepping en echelon sets of fractures. Fractures 34A, 34B, and 34F-341 coincide with mapped traces or lie on the projections of mapped traces of the Las Positas Fault zone. Fracture 34C displays about $1.5 \mathrm{~mm}$ left-lateral strike slip displacement. Postearthquake propagation of fractures $C, E$, and $F$ apparently occurred; the cracks extended through and beyond spots of blue spray paint which reportedly inarked the ends of the cracks at the time the paint was applied. Surfaces of all fractures at location 34 exposed fresh, black asphalt. Commonly, pebbles had been "popped" from their position adjacent to the fracture edge.

The observed left-lateral strike-slip displacements, the right-stepping en echelon distribution of fractures associated with mapped traces of the Las Positas Fault, the unquestioned recency of the fractures and their growth or extension following the earthquakes of 24 and 26 January indicate that the fractures on Tesla Road are probably tectonic in origin. 
Vasco Road, examined 7 and 29 February, five fresh fractures were mapped near the Las Positas Fault intersection at Vasco Road [called "Las Positas Ave" on Fig. 32]. Positions of fractures were measured, using a tape, north from the centerline of Tesla Road, Fracture E, [Fig. 33] a prominent break near the crest of the scarp of the Las Positas Fauit, exhibited left-lateral strike slip displacement of about $0.5 \mathrm{~mm}$. Fractures A-D [Fig. 33] did not exhibit displacements. Fractures A-C occurred only in the southbound lane; only D extended across the centerline of Vasco Road. Fractures A-D trend generally perpendicular to Vasco Road, and have merely opened with slip vectors oriented downslope and perpendicular to fracture trend; these features are interpreted as non-tectonic ground failure.

The small amount of left-lateral strike-slip measured at E coincident with the trace of the Las Positas Fault indicates that surface rupture of the Las Positas Fault extended at least $1.1 \mathrm{~km}$ from Tesla Road to Vasco Road. This interpretation is strongly supported by data from an alinement array which showed about $6 \mathrm{~mm}$ of left-lateral displacement across the fractures at location 35 between 21 February and 26 March (P. W. Harsh, personal communication), even though fracture E showed no obvious change between 7 February and 1 April 1980.

Greenville Road, four fresh fractures without measurable lateral displacement were noted. Three fractures trend perpendicular to. Greenville Road and one is diagonal to it. As mapped on 7 February these features are shown relative to the northeast abutment of the Greenville Road bridge where it crosses the South Bay aqueduct. No extension or growth of fractures was observed on 29 February. The orientation perpendicular to Greenville Road and the absence of growth or a history of propagation indicate a probably non-tectonic origin for these fractures.

Five cracks trending $\mathrm{N} .35^{\circ} \mathrm{E}$. in dirt road and embankments, observed by Brabb on 25 January. Northeast of this location at least 20 cracks trending about N. $40^{\circ}$ E. were visible in the pavement of Vasco Road. Some cracks step to the right and others step to the left; no lateral or vertical displacement was visible on them on 1 April.

Two cracks in Vasco Road, observed by Brabb on 25 January. One crack trends N. $76^{\circ} \mathrm{E}$., and crosses the pavement; the other trends N. $81^{\circ} \mathrm{E}$. and extends across the west lane only. No lateral or vertical displacement visible on I April. 


\section{REFERENCES}

Alameda County Planning Department (1979), Draft-Environmental Impact Report, Livermore-Amador Valley Quarry Reclamation Plan. Alameda County Planning Department, Hayward, CA, p. 67.

Albee, A. L., and J. L. Smith (1966), "Earthquake Characteristics and Fault Activity in Southern California," in Engineering Geology in Southerm California, L. A. Section, Assoc. Engr. Geologists, pp. 9-34.

Almgren, A. A. (1978), "Timing of Tertiary Submarine Canyons and Marine Cycles of Deposition in the Southern Sacramento Valley, California," in Sedimentation in Submarine Canyons, Fans and Trenches, D. J. Stanley and G. Kelling, Eds. (Dowden, Hutchinson and Ross, Stroudsburg), pp. 276-291.

Alt, J. N. (1979), "Analysis of Repeated Geodetic Leveling Data for the Livermore Valley Area, Alameda County, California," Abstracts with Programs (Cordilleran Section of the Geological Society of America, 75th Annual Meeting, San Jose, CA), pp. 65-66.

Bailey, E. H., M. C. Blake, Jr., and D. L. Jones (1970): "Character and Significance of the Ophiolitic Crust that Forms the Basis of the Great Valley Sequence in Western California," Geological Society of America, Abstracts with Programs (Cordilleran Section),2(2), No, 2, pp. 68-69.

Bailey, E. H., W. R. Irwin, and D. L. Jones (1964), Franciscan and Related Rocks and Their Significance in the Geology of Western California, California Division of Mines and Geology, San Francisco, CA, Bulletin 83.

Birkeland, P. W. (1974), Pedology, Weathering and Geomorphological Research, (Oxford University Press, New York), p. 285.

Blake, M. C., Jr., and D. L. Jones (1974), "Origin of Franciscan Melanges in Northern California," in Modem and Ancient Geosynclinal Sedimentation, Dott, R. H., Jr., and Shjaver, R. H., Eds., Society of Econ. Paleontologists and Mineralogists, Spec. Pub. 19, pp. 345-357.

Bonilla, M. G., J. J. Lienkaemper, and J. C. Tinsley (1980), Surface Faulting Near Livermore. California Associated with the January, I980 Earthquakes, U. S. Geological Survey, Menlo Park, CA, Open-File Report 80-523, p. 27.

Brabb, E., H. S. Sonneman, and J. R. Switzer, Jr. (1971), Preliminary Geologic Map of the Mount DiabloByron Area, Contra Costa, Alameda and San Joaquin Counties, California, U. S. Geological Survey, Menlo Park, CA, BDC-28.

Burkland and Associates, Inc. (1975a), Geologic and Seismic Hazards Investigation. Tract 3606, Pleasanton. CA, Report to Applied Soil Mechanics, Inc., by Burkland and Associates, Inc., Mountain View, CA, p. 27.

Burkland and Associates, Inc. (1975b), Tract 3606. Supplemental Information Requested by Alameda County. Letter report to Applied Soil Mechanics, Inc., from Burkland and Assoc., Inc., Mountain View, CA.

Burkland and Associates, Inc. (1975c), Supplemental Investigation Dublin Green, Dublin. Califomia, Report to ENGEO, Inc., by Burkland and Associates, Mountain View, CA, p. 8.

Carpenter, D. W. (1977), Letter to Mr. Earl Hart, California Division of Mines and Geology by D. W. Carpenter, Alameda County Engineering Geologist, County of Alameda, Public Works Agency, Hayward, CA, p. 2. 
CDMG (1980), "The Livermore Earthquakes of January 1980, Contra Costa and Alameda Counties, California," California Geology, Vol, 33, No. 4, pp. 88-92.

CDMG (1980), Strong Motion Instrument Retrieval System (SMIRS), Open File Data.

CDWR (1966): Livermore and Sunol Valleys, Evaluation of Ground Water Resources, Appendix A: Geology. Bulletin 118-2, State of California, Department of Water, Resources, Sacramento, CA, p. 79.

CDWR (1974): Evaluation of Ground Water Resources: Livermore and Sunol Valleys, Bulletin 118-2, Geology, State of California, Department of Water Resources, Sacramento, CA, p, 153.

CDWR (1979): Re-evaluation of Seismic Hazards for Clifton Court Forebay, Bethany Dams and Reservoir. Patterson Reservoir, Del Valle Dam and Lake Del Valle, State of California, Department of Water Resources, Sacramento, CA, p. 77.

Carpenter, D. W. (1975), Geologic Evaluation of Proposed East County Government Center, Sunol Boulevard Hill Site, Pleasamton, CA, Alameda County Public Works Agency, Hayward, CA, Open-File Report, p. 17.

Clark, B. L. (1930), "Tectonics of the Coast Ranges of Middle California," Geol. Soc. America Bull., 4I, 747828.

Cockerham, R. S., F. W. Lester, and W. L. Ellsworth (1980), A Preliminary Report on the Livermore Valley Earthquake Sequence, January 24-February 26, 1980. U. S. Geological Survey, Menlo Park, CA, Open-File Report 80-714, p. 45.

Cooper-Clark and Associates, Inc. (1973), Geotechnical Services, Livermore Properties, Las Positas Valley. California, report to Wilsey and Ham, Inc., by Cooper-Clark and Associates, Palo Alto. CA. p. 21.

Earth Science Associates, Inc. (1971), Geologic and Soil Engineering Investigation of Shannon Park Community Center, Report by Earth Science Associates, Inc., Palo Alto, CA, p. 18.

Ellsworth, W. L., and S. M. Marks (1980), Seismicity of the Livermore Valley, California Region, 1969-1977. U. S. Geological Survey, Menlo Park, CA, Open-File Report 80-515, p. 42.

Ernst, W. G. (1971), "Petrologic Reconnaissance of Franciscan Metagraywackes from the Diablo Range, Central California Coast Ranges," Jour. of Petrology 12, 413-437.

Gibson, W. M., and H. A. Wollenberg (1968), "Investigations for Ground Stability in the Vicinity of the Calaveras Fault, Livermore and Amador Valleys, Alameda County, California," Geol. Soc. of Amer. Bull. 79 , 627-638.

Haltenhoff, F. W. (1979), "The San Ramon Valley Fault, California" in Recent Deformation along the Hayward, Calaveras and Other Fault Zones, Eastern San Francisco Bay Region, California. F. W. Haltenhoff, Ed. (Geological Society of America, 75th Cordilleran Section Meeting, San Jose, CA) p. 61.

Hamilton, W. (1969), "Mesozoic California and the Underflow of the Pacific Mantle," Geol. Soc. Amer. Bull. 80, $2409-2429$.

Helley, E. J., K. R. Lajoie, and D. B. Burke (1972), Geologic Map of Late Cenozoic Deposits, Alameda County. Califomia. U. S. Geological Survey, Menlo Park, CA, Miscellaneous Field Studies Map. MF-429, Scale $1: 62,500$. 
Herd, D. G. (1977), Geologic Map of the Las Positas, Greenville and Verona Faults, Eastern Alameda County. CA., U. S. Gcological Survey, Menlo Park, CA, Open-File Report 77-689.

Herd, D. G. (1979), Personal Communication from D. G. Herd, U.S. Geological Survey to D. W. Carpenter, Lawrence Livermore National Laboratory, Livermore, CA.

Herd, D. G., and E. E. Brabb (1980), Faults at the General Electric Test Reactor Site, Vallecitos Nuclear Center, Pleasanton, California: A Summary Review of Their Geometry, Age of Last Movement, Recurrence, Origin and Tectonic Setting and the Age of the Livermore Gravels, U. S. Geological Survey, Menlo Park, CA, Administrative Report, p, 77.

Huey, A, S. (1948), "Geology of the Tesla Quadrangle, California," California Division of Mines, San Francisco, CA, Bulletin 140, p. 75 .

Hunt, C. B. (1972), Geology of Soils (W. H. Freeman and Co., San Francisco), p. 344.

Irwin, W. R. (1957), "Franciscan Group in Coast Ranges and its Equivalents in the Sacramento Valley, CA," Amer. Assoc. of Petroleum Geologists Bulletin 41, 2284-2297.

John A. Blume and Associates, Inc. (1971), Plutonium Laboratory, Lawrence Livermore Laboratory, Geologic, Seismologic and Foundation Investigations. John A. Blume and Associates, Engineers, San Francisco, CA (report prepared for Maher and Martens-Architects, San Francisco, CA).

John A. Blume and Associates, Inc. (1972), Investigation of Faulting at the Lawrence Livermore Laboratory, Report to University of California, Lawrence Livermore National Laboratory by John A. Blume and Associates, Inc., San Francisco, CA, p. 55.

Judd Hull and Associates (1975), Soil Engineering and Geologic Investigations, Phase II-Site Suitability for Old "Pitch and Put" Course Foothill Road South of Castlewood Drive. Pleasanton Township. Alameda County. California. Report to Board of Directors, The Castlewood Country Club by Judd Hull and Associates, Hayward, CA, p. 25.

Judd Hull and Associates (1977) Engineering Geology Investigation for Proposed Single Family Residence. East Side of South Vasco Road Near Livermore, Alameda County, Califomia. Report to Mr. Ron Baker, Woodren Realty by Judd Hull and Associates, Hayward, CA, p. 15.

Judd Hull and Associates (1977b), Geologic Investigation for Proposed Civic Center Additions 200 Bernal A venue, Pleasanton, Califormia, Report to City of Pleasanton, CA, by Judd Hull and Associates, Hayward, CA, p. 24.

Kerr, R. A. (1979), "Prospects for Earthquake Prediction Wane," Science 206, 542-545.

Ku, T. L., and L. U. Joshi (1980), "Dating Terrestrial Carbonate Cementation with Uranium-Series Isotopes" in Management of Environment, B. Patel, Ed. (Wiley-Eastern, Ltd., Bombay) pp. 551-557.

Ku, T. L., W. B. Bull, S. T. Freeman, and K. G. Knauss (1979), " ${ }^{230}{ }^{T h}{ }^{234} U$ Dating of Pedogenic Carbonates in Gravelly Desert Soils of Vidal Valley, Southeastern California," Geol. Soc. Am. Bull. 90, 1063-1073.

Lawson, A. C. and others (1908), The California Earihquake of April 18, 1906, Report of the State Earthquake Investigation Commission, Carnegie Institute, Washington DC, Pub. 87, 2 Vols. 
Nilsen, T. H. (1979), "Early Cenozoic Stratigraphy, Tectonics and Sedimentation of the Central Diablo Range Between Hollister and New Idria," in Geology of the Central Diablo Range Between Hollister and New Idria. CA, T. H. Nilsen and T. W. Dibblee, Jr., Eds., Field Trip Guidebook for the Geol, Soc. Amer. Cordilleran Sec. Meeting, San Jose, CA, pp. 31-55.

Page, B. M. (1966), "Geology of the Coast Ranges of California," in Geology of Northern California, E. H. Bailey, Ed.. California Division of Mines and Geology, San Francisco, CA. Bulletin 190.

Radbruch, D. H. (1968), "New Evidence of Historic Fuult Activity in Alumeda, Contru Costu and Suntu Clara Counties, California," in Proceedings of the Conference on Geologic Proh,ems of San Andreas Frait System. Stanford University Publications in Geological Sciences, V. 11, pp. 46-54.

Rice, S., E. Stephens, and C. Real (1979), Geologic Evaluation of the General Electric Test Reactor Site. Vallecitos, Alameda County, California, California Division of Mines and Geology, San Franciso, CA, Special Publication 56, $\bar{p} .19$.

Robinson, S. (1980), Personal Communicution from S, Robinson, U. S, Geological Survey, Menlo Park, CA to K. Knauss, Lawrence Livermore National Laboratory, Livermore, CA,

Saul, R. B. (1975), "Geology of the Southeast Slope of the Santa Susana Mountains and Geologic Effects of" San Fernando Earthquake," in San Fernando, California Earthquake of February 9, 1971, California Division of Mines and Geology, San Francisco, CA, Bulletin 196.

Sieh, K. E. (1978), "Prehistoric Large Earthquakes Produced by Slip on the San Andreas Fault at Pallett Creek, CA," J. Geophys. Res. 83, 3907-3939.

Slosson, J. E. (1974), Stale of California, Special Studies Zones, Dublin Quadrangle, California Division of Mines and Geology, San Francisco. CA, Unnumbered map, Scale 1:24,000.

Sullivan, K., and J. Waters (1980), "History of Mount Diablo Coalfield, Contra Costa County, California," California Geology. 3(3) $51-59$.

Tokarz, F. J., and G. Shaw (1980), Seismic Safety of the Plutonium Facility (Bldg. 332), Lawrence Livermore National Laboratory, Livermore, CA, UCRL-52786, p. 65.

Tovse. D. (1979), Staff Memorandum to D. O. Emerson, Head Geology Section, Physical Sciences Division, Lawrence Livermore National Laboratory, Livernore, CA.

URS/John A. Blume and Associates, Inc. (1978), Seismic and Geologic Invesvigations of the Sandia Livermote Laboratory Site and Structural Investigations of the Trillum Research Facility, Report to Sandia Laboratorics, Livermore CA, by URS/John A. Blume and Associates, Inc., San Francisco, CA, p. 106.

Wesson, R. L. E. J. Helley, K. R. Lajoie, and C. M. Wentworth (1975), "Fuults und Future Earthquakes," in Studies for Seismic Zonation of the San Francisco Bay Region. R. D. Borcherdt, Ed., U. S. Geological Survey. Menlo Park, CA, Prof, Paper a i-A, pp. 5-30.

Wight, L. G. (1974), A Geological and Seismological Investigation of the Lawrence Livermore Laboratory Site. Lawrence Livermore National Laboratory, Livermore, CA, UCRL-51592, p. 38.

Youd, T. L., and S. N. Hoose (1978), Historic Ground Futlures in Northern Califormia Triggered by Earthquakes. U. S. Geological Survey, Menlo Park, CA, Prof. Paper 993. 